\title{
Ground-Water, Surface-Water, and Water-Chemistry Data, Black Mesa Area, Northeastern Arizona - 1999
}

\author{
Open-File Report 00-453
}

Prepared in cooperation with the BUREAU OF INDIAN AFFAIRS and the ARIZONA DEPARTMENT OF WATER RESOURCES
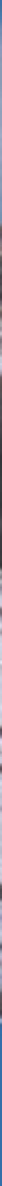


\section{Ground-Water, Surface-Water, and Water- Chemistry Data, Black Mesa Area, Northeastern Arizona-1999}

Open-File Report 00—453

Prepared in cooperation with the

BUREAU OF INDIAN AFFAIRS and the ARIZONA DEPARTMENT OF WATER RESOURCES 


\section{U.S. DEPARTMENT OF THE INTERIOR \\ BRUCE BABBITT, Secretary}

U.S. GEOLOGICAL SURVEY

Charles G. Groat, Director

The use of firm, trade, and brand names in this report is for identification purposes only and does not constitute endorsement by the U.S. Geological Survey.

For additional information write to:

District Chief

U.S. Geological Survey

Water Resources Division

520 N. Park Avenue, Suite 221

Tucson, AZ 85719-5035
Copies of this report can be purchased from:

U.S. Geological Survey

Information Services

Box 25286

Federal Center

Denver, C0 80225-0046

Information regarding research and data-collection programs of the U.S. Geological Survey is available on the Internet via the World Wide Web. You may connect to the home page for the Arizona District Office using the URL http://az.water.usgs.gov. 


\section{CONTENTS}

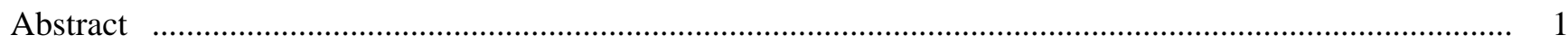

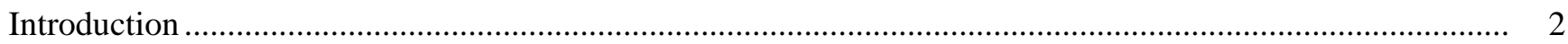

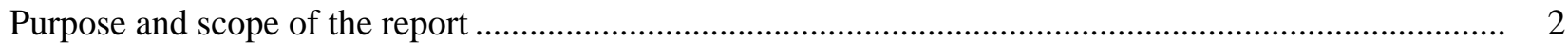

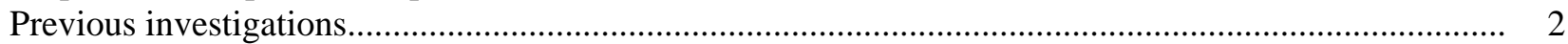

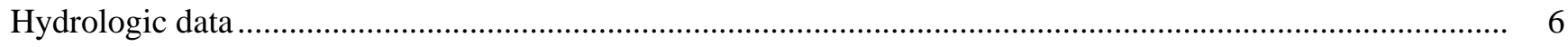

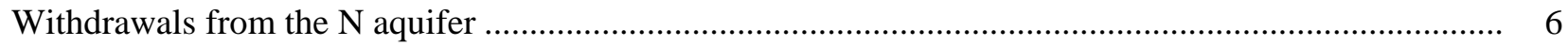

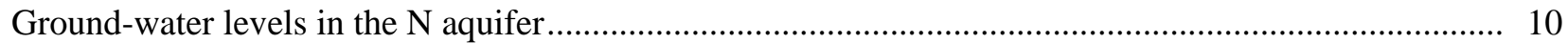

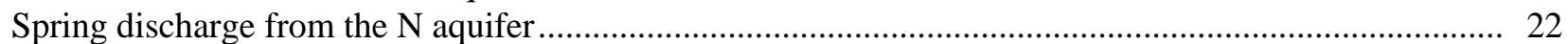

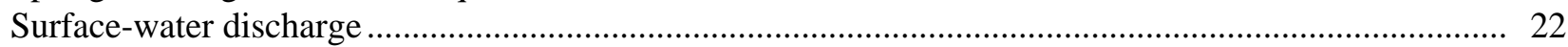

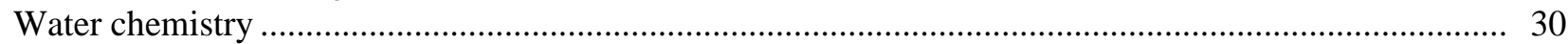

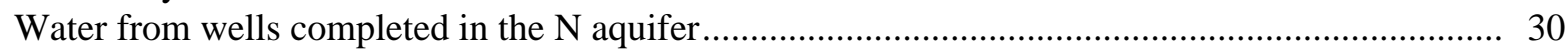

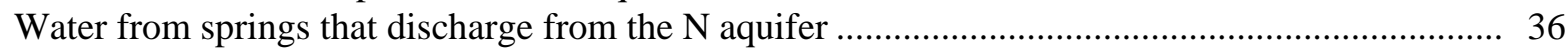

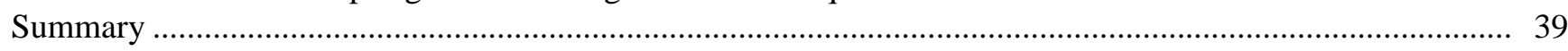

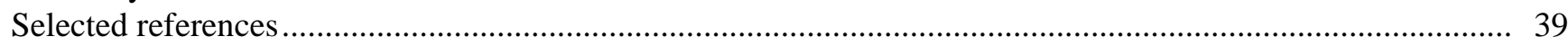




\section{FIGURES}

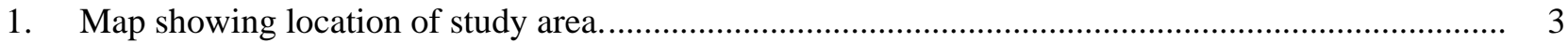

2. Diagram showing rock formations and hydrogeologic units of the Black Mesa area, Arizona.......... 4

3. Graph showing withdrawals from the N aquifer, Black Mesa area, Arizona, 1965-99.................... 7

4. Map showing location of well systems monitored for withdrawals from the $\mathrm{N}$ aquifer, Black Mesa area, Arizona, 1999........................................................................................... 8

5. Map showing water-level changes in N-aquifer wells from the prestress period to 1999, Black Mesa area, Arizona.......

6. Graph showing rates of annual water-level changes for observation wells completed in the $\mathrm{N}$ aquifer, Black Mesa area, Arizona, 1983-99.

7. Hydrographs showing water-level changes in wells used for annual water-level measurements, Black Mesa area, Arizona, 1950-2000.

8. Hydrographs showing measured water-level changes in continuous-record observation wells BM1-BM6, 1963-99, and simulated water-level changes, 1965-99, Black Mesa area, Arizona.

9. Map showing surface-water and water-chemistry data-collection sites, Black Mesa area, Arizona, 1999.

10. Graphs showing annual average discharge and median winter discharge, Moenkopi Wash (09401260), Laguna Creek (09379180), Dinnebito Wash (09401110), and Polacca Wash (09400568), Black Mesa area, Arizona.

A. Annual average discharge for calendar years 1977-99

B. Median discharge for November, December, January, and February for water years 1977-99

11. Trilinear diagram showing relative compositions of ground water from the $\mathrm{N}$ aquifer, Black Mesa area, Arizona, 1999.

12. Map showing water chemistry and distribution of dissolved solids in the $\mathrm{N}$ aquifer, Black Mesa area, Arizona, $1999 .$.

13. Graph showing dissolved-solids concentrations in water from wells Keams Canyon PM2, Rough Rock PM5, Forest Lake NTUA 1, and Kayenta PM2, Black Mesa area, Arizona, 1982-99. 


\section{TABLES}

1. Withdrawals from the $\mathrm{N}$ aquifer, Black Mesa area, Arizona, 1965-99 ...................................... 5

2. Identification numbers, names, and locations of study wells, Black Mesa area, Arizona ................. 6

3. Withdrawals from the $\mathrm{N}$ aquifer by well system, Black Mesa area, Arizona, 1999 ......................... 9

4. Flowmeter-test results for municipal wells that are completed in the $\mathrm{N}$ aquifer, Black Mesa area, Arizona, 1999.

5. Water-level changes in wells completed in the N aquifer, Black Mesa area, Arizona, prestress period to 1999 ....

6. Well-construction characteristics, top of $\mathrm{N}$ aquifer, and type of data collected for study wells, Black Mesa area, Arizona, 1999

7. Discharge measurements of selected springs, Black Mesa area, Arizona, 1952-99....................... 23

8. Discharge data, Moenkopi Wash at Moenkopi, Arizona (09401260), calendar year 1999 ............... 25

9. Discharge data, Laguna Creek at Dennehotso, Arizona (09379180), calendar year 1999................. 26

10. Discharge data, Dinnebito Wash near Sand Springs, Arizona (09401110), calendar year 1999

11. Discharge data, Polacca Wash near Second Mesa, Arizona (09400568), calendar year 1999.

12. Date that data collection began and drainage areas for streamflow-gaging stations,

Black Mesa area, Arizona.....

13. Physical properties and chemical analyses of water from selected industrial and municipal wells completed in the N aquifer, Black Mesa area, Arizona, 1999

14. Specific conductance and concentrations of selected chemical constituents in water from industrial and municipal wells completed in the $\mathrm{N}$ aquifer, Black Mesa area, Arizona, 1964-99....

15. Physical properties and chemical analyses of water from selected springs that discharge from the $\mathrm{N}$ aquifer, Black Mesa area, Arizona, 1999

16. Specific conductance and concentrations of selected chemical constituents in water from selected springs that discharge from the $\mathrm{N}$ aquifer, Black Mesa area, Arizona, 1948-99....

\section{CONVERSION FACTORS}

\begin{tabular}{rll}
\hline Multiply & By & To obtain \\
\hline inch (in) & 2.54 & centimeter \\
inch (in) & 25.4 & millimeter \\
foot $(\mathrm{ft})$ & 0.3048 & meter \\
mile $(\mathrm{mi})$ & 1.609 & kilometer \\
square $\mathrm{mile}\left(\mathrm{mi}^{2}\right)$ & 2.590 & square kilometer \\
acre-foot $(\mathrm{acre}-\mathrm{ft})$ & 0.001233 & cubic hectometer \\
cubic foot per second $(\mathrm{ft} / \mathrm{s})$ & 0.02832 & cubic meter per second \\
gallon per minute $(\mathrm{gal} / \mathrm{min})$ & 0.06309 & liter per second \\
gallon per day $(\mathrm{gal} / \mathrm{d})$ & 0.003785 & cubic meter per day \\
\hline
\end{tabular}


Temperature in degrees Celsius $\left({ }^{\circ} \mathrm{C}\right)$ may be converted to degrees Fahrenheit $\left({ }^{\circ} \mathrm{F}\right)$ as follows:

$$
{ }^{\circ} \mathrm{F}=\left(1.8^{\circ} \mathrm{C}\right)+32
$$

\section{ABBREVIATED WATER-QUALITY UNITS}

Chemical concentration and water temperature are given only in metric units. Chemical concentration in water is given in milligrams per liter $(\mathrm{mg} / \mathrm{L})$ or micrograms per liter $(\mu \mathrm{g} / \mathrm{L})$. Milligrams per liter is a unit expressing the solute mass (milligrams) per unit volume (liter) of water. One thousand micrograms per liter is equivalent to 1 milligram per liter. For concentrations less than 7,000 milligrams per liter, the numerical value is about the same as for concentrations in parts per million. Specific conductance is given in microsiemens per centimeter at 25 degrees Celsius $\left(\mu \mathrm{S} / \mathrm{cm}\right.$ at $\left.25^{\circ} \mathrm{C}\right)$.

\section{VERTICAL DATUM}

Sea level: In this report, "sea level" refers to the National Geodetic Vertical Datum of 1929 (NGVD of 1929)—A geodetic datum derived from a general adjustment of the first-order level nets of both the United States and Canada, formerly called Sea Level Datum of 1929. Altitude, as used in this report, refers to distance above or below sea level. 


\title{
Ground-Water, Surface-Water, and Water-Chemistry Data, Black Mesa Area, Northeastern Arizona-1999
}

\author{
By Blakemore E. Thomas and Margot Truini
}

\begin{abstract}
The $\mathrm{N}$ aquifer is the major source of water in the 5,400-square-mile area of Black Mesa in northeastern Arizona. Availability of water is an important issue in this area because of continued industrial and municipal use, a growing population, and a precipitation of only about 6 to 12 inches per year.

The monitoring program in Black Mesa has been operating since 1971 and is designed to determine the long-term effects of ground-water withdrawals from the $\mathrm{N}$ aquifer for industrial and municipal uses. The monitoring program includes measurements of (1) ground-water pumping, (2) ground-water levels, (3) spring discharge, (4) surface-water discharge, and (5) ground-water chemistry.

In 1999, total ground-water withdrawals were 7,110 acre-feet, industrial use was 4,210 acre-feet, and municipal use was 2,900 acre-feet. From 1998 to 1999, total withdrawals increased by 0.7 percent, industrial use increased by 4 percent, and municipal use decreased by 4 percent.

From 1998 to 1999, water levels declined in 11 of 15 wells in the unconfined part of the aquifer, and the median decline was 0.7 foot. Water levels declined in 14 of 16 wells in the confined part of the aquifer, and the median decline was 1.2 feet.

From the prestress period (prior to 1965) to 1999, the median water-level decline in 31 wells was 10.6 feet. Median water-level changes were 0.0 foot for 15 wells in the unconfined part of the aquifer and -45.5 feet in 16 wells in the confined part.

From 1998 to 1999, discharges were measured annually at four springs. Discharges declined 30 percent and 3 percent at 2 springs, did not change at 1 spring, and increased by 11 percent at 1 spring. For the past 10 years, discharges from the four springs have fluctuated; however, an increasing or decreasing trend was not observed.

Continuous records of surface-water discharge have been collected from July 1976 to 1999 at Moenkopi Wash, July 1996 to 1999 at Laguna Creek, June 1993 to 1999 at Dinnebito Wash, and April 1994 to 1999 at Polacca Wash. Median flows for November, December, January, and February of each water year are used as an index of ground-water discharge to those streams. Increasing or decreasing trends are not apparent in these median winter flows for the periods of record.

In 1999, water samples were collected from 12 wells and 4 springs and analyzed for selected chemical constituents. Dissolved-solids concentrations ranged from 91 to 630 milligrams per liter. Water samples from 10 of the wells and the 4 springs had less than 350 milligrams per liter of dissolved solids. Waterchemistry data are available for nine wells and four springs from about the mid-1980s. For that time period, the data from those sites have remained fairly stable. From 1987 to 1999, concentrations of dissolved solids, chloride, and sulfate may have increased slightly in samples from Moenkopi School Spring.
\end{abstract}




\section{INTRODUCTION}

The Black Mesa area includes about 5,400 $\mathrm{mi}^{2}$ in northeastern Arizona (fig. 1) and has a diverse topography that includes flat plains, mesas, and incised drainages. Black Mesa is about 2,000 $\mathrm{mi}^{2}$, is bounded by 2,000-foot cliffs on the north and northeast sides, and slopes gradually downward to the south and southwest. Availability of water is an important issue in the study area because of continued ground-water withdrawals, a growing population, and an annual precipitation that averages only about 6 to 12 in.

The $\mathrm{N}$ aquifer is the major source of water for industrial and municipal uses in the Black Mesa area. The $\mathrm{N}$ aquifer consists of three formations - the Navajo Sandstone, the Kayenta Formation, and the Lukachukai Member ${ }^{1}$ of the Wingate Sand- stone, which are hydraulically connected and function as a single aquifer (fig. 2). Peabody Western Coal Company is the principal industrial user of water, and the Navajo Nation and Hopi Tribe are the principal domestic and municipal users.

Withdrawals from the $\mathrm{N}$ aquifer in the Black Mesa area have been increasing during the last 30 years (table 1). Peabody Western Coal Company began operating a strip mine in the northern part of the mesa in 1968. The quantity of water pumped by the company increased from about 100 acre-ft in 1968 to a maximum of 4,740 acre-ft in 1982. About 4,210 acre-ft of water was pumped in 1999. Withdrawals for municipal use from the $\mathrm{N}$ aquifer have increased steadily from an estimated 250 acre-ft in 1968 to 2,900 acre-ft in 1999.

The Navajo Nation and the Hopi Tribe have been concerned about the long-term effects of withdrawals from the $\mathrm{N}$ aquifer on available water supplies, on stream and spring discharge, and on ground-water chemistry. In 1971, these concerns led to the establishment of a monitoring program of the water resources in Black Mesa by the U.S. Geological Survey (USGS) in cooperation with the Arizona Department of Water Resources (ADWR). In 1983, the Bureau of Indian Affairs (BIA) joined the cooperative effort. Since 1983, the Navajo Tribal Utility Authority

\footnotetext{
${ }^{1}$ The name Lukachukai Member was formally abandoned by Dubiel (1989) and is used herein for report continuity in the monitoring program as it relates to that part of the Wingate Sandstone included in the N aquifer.
}

(NTUA); Peabody Western Coal Company; the Hopi Tribe; and the Western Navajo Agency, Chinle Agency, and Hopi Agency of the BIA have assisted in the collection of hydrologic data.

\section{Purpose and Scope of the Report}

This report presents the results of ground- water, surface-water, and water-chemistry monitoring in the Black Mesa area generally from January to December 1999. The monitoring is designed to determine the effects of industrial and municipal pumpage from the $\mathrm{N}$ aquifer on ground-water levels, stream and spring discharge, and water chemistry. Continuous and periodic data are collected for ground water and surface water. Ground-water data include pumpage, water levels, spring discharges, and water chemistry. Surfacewater data include discharges at four continuousrecord streamflow-gaging stations.

\section{Previous Investigations}

Seventeen progress reports on the monitoring program for the Black Mesa area have been prepared by the USGS (U.S. Geological Survey, 1978; G.W. Hill, hydrologist, written commun., 1982, 1983; Hill, 1985; Hill and Whetten, 1986; Hill and Sottilare, 1987; Hart and Sottilare, 1988, 1989; Sottilare, 1992; Littin, 1992, 1993; Littin and Monroe, 1995a, 1995b, 1996, 1997; Littin and others, 1999; Truini and others, 2000). Most of the data from the monitoring program are contained in these reports, except for continuous stream- discharge and periodic water-quality data from Moenkopi Wash collected before the 1986 water year; those data were published in U.S. Geological Survey (1963-64a, b; 1965-74a, b; 1976-83); White and Garrett $(1984,1986,1987,1988)$; Boner and others (1989, 1990, 1991, 1992); Smith and others (1993, 1994, 1995, 1996, 1997); and Tadayon and others (1998, 1999). Before the monitoring program, a large data-collection effort resulted in a compilation of well and spring data for the Navajo and Hopi Indian Reservations (Davis and others, 1963). 


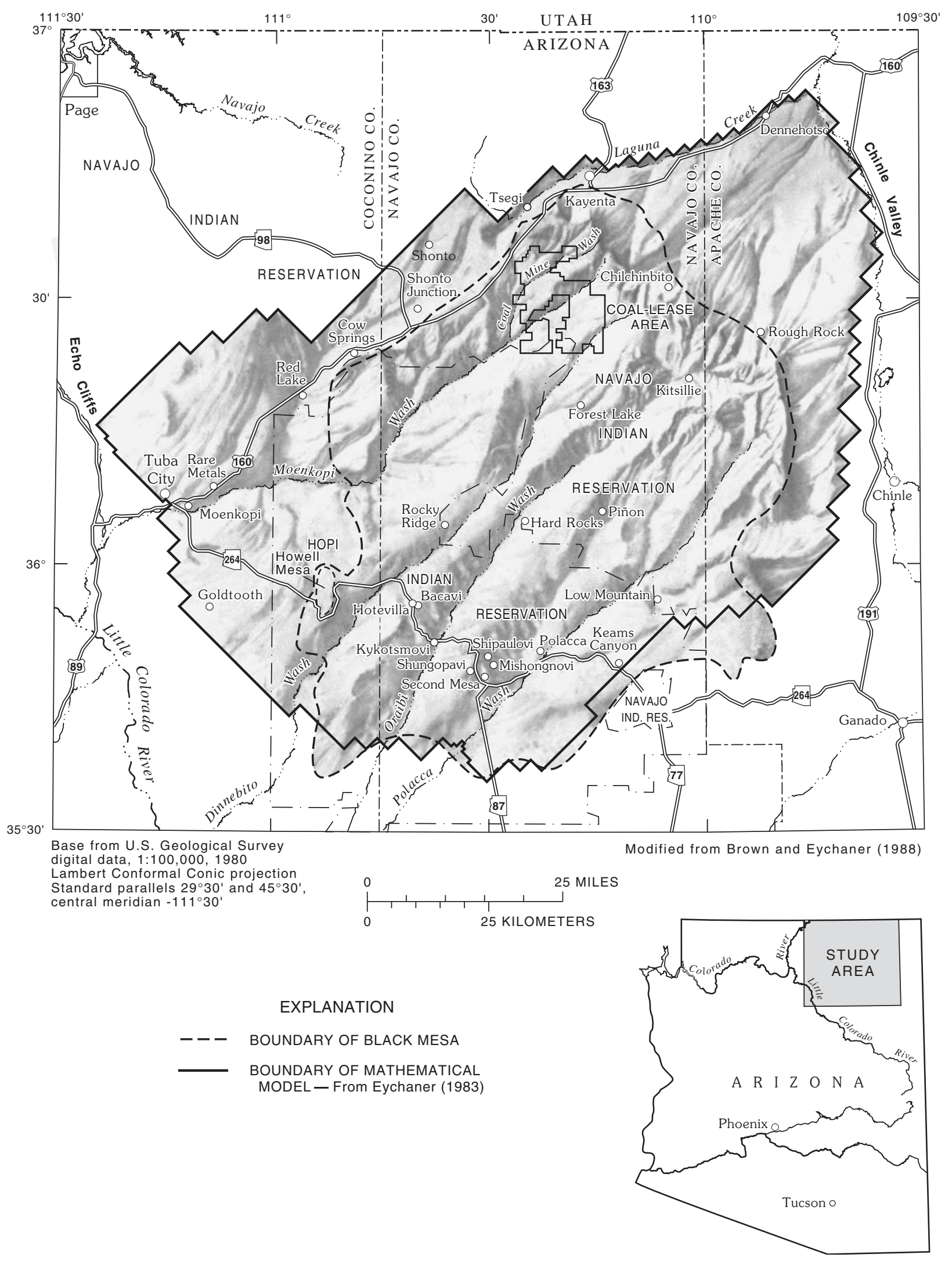

Figure 1. Location of study area. 


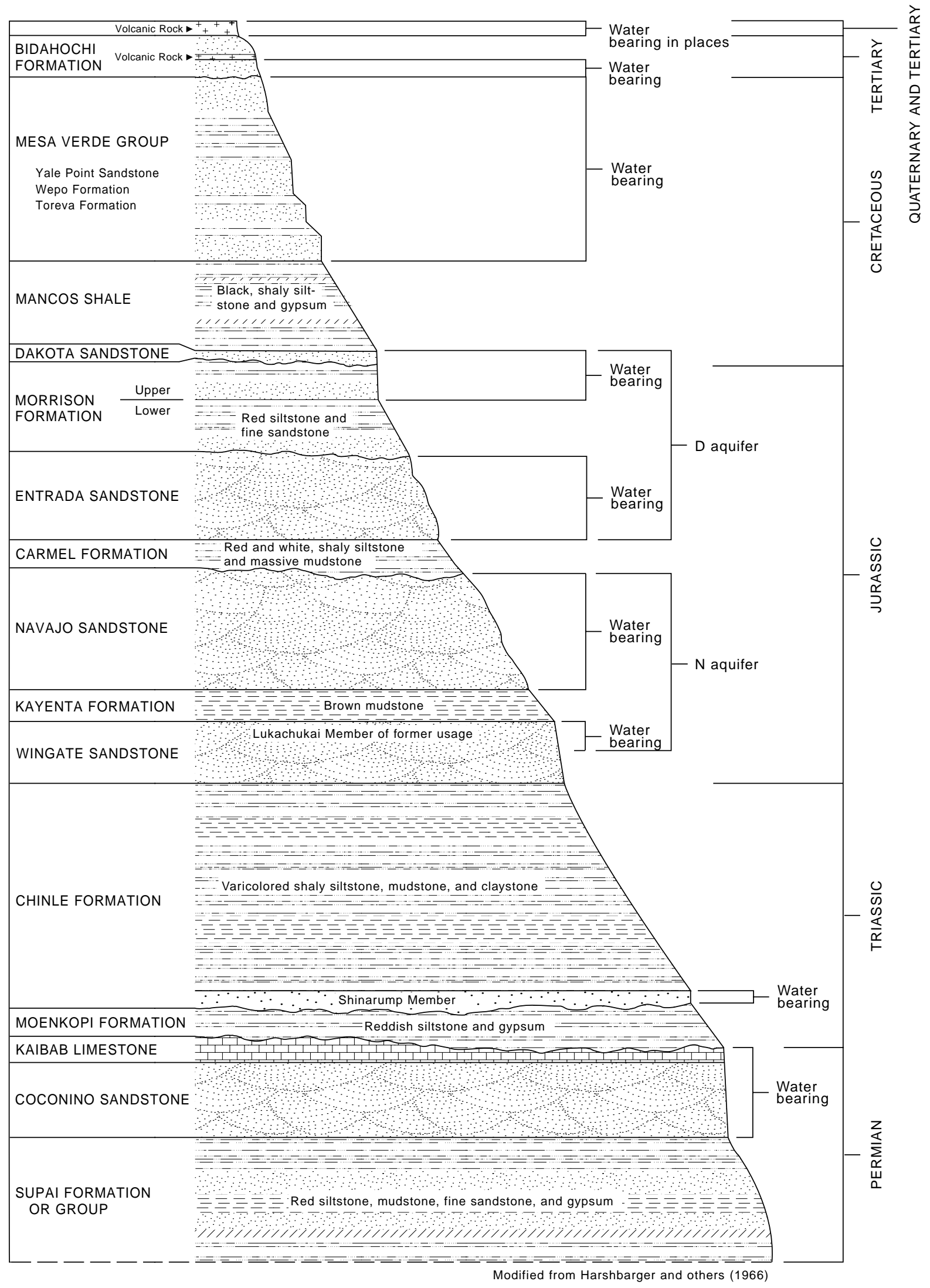

Figure 2. Rock formations and hydrogeologic units of the Black Mesa area, Arizona. The $\mathrm{N}$ aquifer is approximately 1,000 feet thick. 
Table 1. Withdrawals from the $\mathrm{N}$ aquifer, Black Mesa area, Arizona, 1965-99

[Values are rounded to nearest 10 acre-feet. Data for 1965-79 from Eychaner (1983). Total withdrawals in Littin and Monroe (1996) were for the confined part of the aquifer]

\begin{tabular}{|c|c|c|c|c|c|c|c|c|c|}
\hline \multirow[b]{2}{*}{ Year } & \multirow[b]{2}{*}{ Industrial $^{1}$} & \multicolumn{2}{|c|}{ Municipal ${ }^{2,3}$} & \multirow{2}{*}{$\begin{array}{c}\text { Total } \\
\text { withdrawals }\end{array}$} & \multirow[b]{2}{*}{ Year } & \multirow[b]{2}{*}{ Industrial| $^{1}$} & \multicolumn{2}{|c|}{ Municipal ${ }^{2,3}$} & \multirow{2}{*}{$\begin{array}{c}\text { Total } \\
\text { withdrawals }\end{array}$} \\
\hline & & Confined & Unconfined & & & & Confined & Unconfined & \\
\hline 1965 & 0 & 50 & 20 & 70 & 1983 & 4,460 & 1,360 & 1,280 & 7,100 \\
\hline 1966 & 0 & 110 & 30 & 140 & 1984 & 4,170 & 1,070 & 1,400 & 6,640 \\
\hline 1967 & 0 & 120 & 50 & 170 & 1985 & 2,520 & 1,040 & 1,160 & 4,720 \\
\hline 1968 & 100 & 150 & 100 & 350 & 1986 & 4,480 & 970 & 1,260 & 6,710 \\
\hline 1969 & 40 & 200 & 100 & 340 & 1987 & 3,380 & 1,130 & 1,280 & 6,240 \\
\hline 1970 & 740 & 280 & 150 & 1,170 & 1988 & 4,090 & 1,250 & 1,310 & 6,650 \\
\hline 1971 & 1,900 & 340 & 150 & 2,390 & 1989 & 3,450 & 1,070 & 1,400 & 5,920 \\
\hline 1972 & 3,680 & 370 & 250 & 4,300 & 1990 & 3,430 & 1,170 & 1,210 & 5,810 \\
\hline 1973 & 3,520 & 530 & 300 & 4,350 & 1991 & 4,020 & 1,140 & 1,300 & 6,460 \\
\hline 1974 & 3,830 & 580 & 360 & 4,770 & 1992 & 3,820 & 1,180 & 1,410 & 6,410 \\
\hline 1975 & 3,500 & 600 & 510 & 4,610 & 1993 & 3,700 & 1,250 & 1,570 & 6,520 \\
\hline 1976 & 4,180 & 690 & 640 & 5,510 & 1994 & 4,080 & 1,210 & 1,600 & 6,890 \\
\hline 1977 & 4,090 & 750 & 730 & 5,570 & 1995 & 4,340 & 1,220 & 1,510 & 7,070 \\
\hline 1978 & 3,000 & 830 & 930 & 4,760 & 1996 & 4,010 & 1,380 & 1,650 & 7,040 \\
\hline 1979 & 3,500 & 860 & 930 & 5,290 & 1997 & 4,130 & 1,380 & 1,580 & 7,090 \\
\hline 1980 & 3,540 & 910 & 880 & 5,330 & 1998 & 4,030 & 1,440 & 1,590 & 7,060 \\
\hline 1981 & 4,010 & 960 & 1,000 & 5,970 & 1999 & 4,210 & 1,420 & 1,480 & 7,110 \\
\hline 1982 & 4,740 & 870 & 960 & 6,570 & & & & & \\
\hline
\end{tabular}

${ }^{1}$ Metered pumpage from the confined part of the aquifer by Peabody Western Coal Company.

2 Does not include withdrawals from the wells equipped with windmills.

${ }^{3}$ Includes estimated pumpage, 1965-73, and metered pumpage, 1974-79, at Tuba City; metered pumpage at Kayenta and estimated pumpage at Chilchinbito, Rough Rock, Piñon, Keams Canyon, and Kykotsmovi before 1980; metered and estimated pumpage furnished by the Navajo Tribal Utility Authority and the Bureau of Indian Affairs and collected by the U.S. Geological Survey, 1980-85; and metered pumpage furnished by the Navajo Tribal Utility Authority, the Bureau of Indian Affairs, various Hopi Village Administrations, and the U.S. Geological Survey, 1986-99.

Many interpretive studies have been done in the Black Mesa area. Cooley and others (1969) made the first comprehensive evaluation of the regional hydrogelogy of the Black Mesa area. Eychaner (1983) developed a two-dimensional mathematical model of ground-water flow in the $\mathrm{N}$ aquifer. A few years later, Brown and Eychaner (1988) converted the model to a new program and a finer spatial grid, revised estimates of selected aquifer characteristics, and recalibrated the model. GeoTrans, Inc. (1987) also developed a twodimensional model of the $\mathrm{N}$ aquifer in the 1980s. Waterstone Environmental Hydrology and Engineering (1995) conducted a sensitivity analysis of the models by Brown and Eychaner (1988) and GeoTrans, Inc. (1987). In the late 1990s, HSIGeoTrans, Inc. and Waterstone Environmental Hydrology and
Engineering, Inc. (1999) developed a detailed threedimensional mathematical model of the $\mathrm{D}$ and $\mathrm{N}$ aquifers.

Kister and Hatchett (1963) made the first comprehensive evaluation of the chemistry of water from wells and springs in the Black Mesa area.

HSIGeoTrans, Inc. (1993) evaluated the major-ion and isotopic chemistry of the $\mathrm{D}$ and $\mathrm{N}$ aquifers. Lopes and Hoffmann (1997) analyzed ground-water ages, recharge, and hydraulic con- ductivity of the $\mathrm{N}$ aquifer using geochemical techniques. Zhu and others (1998) estimated ground-water recharge using isotopic data and flow estimates from the model developed by GeoTrans, Inc. (1987). 


\section{HYDROLOGIC DATA}

In 1999, the Black Mesa monitoring program included metering and estimating ground-water withdrawals, measuring depth to ground water, measuring discharge in streams and springs, and collecting and analyzing water samples from wells and springs. Ground-water withdrawals from 34 well systems, water levels at 6 observation wells, and surface-water discharge at 4 sites were monitored continuously. Discharge at 4 springs and ground-water levels at 25 wells were measured annually. Spring discharges were measured in December 1999. Groundwater levels were measured between October 1999 and February 2000. The goal was to measure all groundwater levels between October and December 1999; however, adverse weather conditions forced a delay and 11 wells were measured in January or February 2000. Water samples were collected from 12 wells and 4 springs in December 1999 or January
2000 and analyzed for chemical constituents.

Identification and location information for the 42 wells used for water-level measurements and water-quality sampling is shown in table 2 .

\section{Withdrawals from the $\mathbf{N}$ Aquifer}

Withdrawals from the $\mathrm{N}$ aquifer are separated into three categories-(1) industrial use from the confined part of the aquifer, (2) municipal use from the confined part of the aquifer, and (3) municipal use from the unconfined part of the aquifer (table 1, fig. 3). The industrial category includes eight wells at the well field of Peabody Western Coal Company in northern Black Mesa (fig. 4). The Bureau of Indian Affairs, Navajo Tribal Utility Authority, and Hopi Tribe operate about 70 municipal wells. Withdrawals from the $\mathrm{N}$ aquifer were compiled primarily on the basis of metered data (tables 1 and 3).

Table 2. Identification numbers, names, and locations of study wells, Black Mesa area, Arizona

[Dashes indicate no data]

\begin{tabular}{|c|c|c|c|c|c|}
\hline $\begin{array}{l}\text { U.S. Geological Survey } \\
\text { identification number }\end{array}$ & $\begin{array}{l}\text { U.S. Geological Survey } \\
\text { well location }\end{array}$ & Common name or location & $\begin{array}{l}\text { Bureau of } \\
\text { Indian Affairs } \\
\text { site number }\end{array}$ & $\begin{array}{c}\text { Latitude } \\
\text { (degrees, } \\
\text { minutes, } \\
\text { seconds) }\end{array}$ & $\begin{array}{c}\text { Longitude } \\
\text { (degrees, } \\
\text { minutes, } \\
\text { seconds) }\end{array}$ \\
\hline 355023110182701 & $094-03.23 \times 11.05$ & Keams Canyon PM2 & --- & 355025 & 1101827 \\
\hline 355215110375001 & 095-07.28x08.90 & Kykotsmovi PM2 & --- & 355212 & 1103742 \\
\hline 355230110365801 & 095-06.50x08.61 & Kykotsmovi PM1 & --- & 355232 & 1103657 \\
\hline 355236110364501 & $095-06.34 \times 08.54$ & Kykotsmovi PM3 & --- & 355235 & 1103645 \\
\hline 355648110475501 & $096-02.73 \times 03.65$ & Howell Mesa & $6 \mathrm{H}-55$ & 355649 & 1104754 \\
\hline 360055110304001 & $075-00.61 \times 16.21$ & BM observation well 5 & $4 \mathrm{~T}-519$ & 360051 & 1103041 \\
\hline 360217111122601 & $077-11.59 \times 14.61$ & Tuba City & $3 \mathrm{~K}-325$ & 360217 & 1111226 \\
\hline 360418110352701 & $075-05.09 \times 12.30$ & Rocky Ridge PM2 & --- & 360418 & 1103527 \\
\hline 360614110130801 & $073-12.26 \times 10.09$ & Piñon PM6 & --- & 360610 & 1101315 \\
\hline 360734111144801 & $077-13.77 \times 08.52$ & Tuba City & $3 \mathrm{~T}-333$ & 360734 & 1111448 \\
\hline 360904111140201 & 077-13.05x06.81 & Tuba City NTUA 1 & 3T-508 & 360904 & 1111402 \\
\hline 360918111080701 & $077-07.55 \times 06.55$ & Tuba City Rare Metals 2 & --- & 360918 & 1110807 \\
\hline 360953111142401 & $077-13.38 \times 05.87$ & Tuba City NTUA 4 & $3 \mathrm{~T}-546$ & 360954 & 1111425 \\
\hline 361225110240701 & $074-08.95 \times 02.95$ & BM observation well 6 & --- & 361228 & 1102436 \\
\hline 361737110180301 & $056-02.85 \times 14.19$ & Forest Lake NTUA 1 & $4 \mathrm{~T}-523$ & 361737 & 1101801 \\
\hline 361832109462701 & $054-01.35 \times 13.20$ & Rough Rock & $10 \mathrm{~T}-258$ & 361832 & 1094627 \\
\hline 361933110565001 & $058-11.04 \times 12.16$ & Red Lake PM1 & --- & 361924 & 1105654 \\
\hline 362043110030501 & --- & Kitsillie NTUA 2 & --- & 362043 & 1100305 \\
\hline 362149109463301 & $054-01.47 \times 09.39$ & Rough Rock & 10R-111 & 362149 & 1094633 \\
\hline
\end{tabular}


Table 2. Identification numbers, names, and locations of study wells, Black Mesa area, Arizona-Continued

\begin{tabular}{|c|c|c|c|c|c|}
\hline $\begin{array}{l}\text { U.S. Geological Survey } \\
\text { identification number }\end{array}$ & $\begin{array}{l}\text { U.S. Geological Survey } \\
\text { well location }\end{array}$ & Common name or location & $\begin{array}{c}\text { Bureau of } \\
\text { Indian Affairs } \\
\text { site number }\end{array}$ & $\begin{array}{l}\text { Latitude } \\
\text { (degrees, } \\
\text { minutes, } \\
\text { seconds) }\end{array}$ & $\begin{array}{l}\text { Longitude } \\
\text { (degrees, } \\
\text { minutes, } \\
\text { seconds) }\end{array}$ \\
\hline 362406110563201 & $058-10.73 \times 06.78$ & White Mesa Arch & $1 \mathrm{~K}-214$ & 362406 & 1105632 \\
\hline 362418109514601 & $054-06.30 \times 06.52$ & Rough Rock PM5 & --- & 362420 & 1095146 \\
\hline 362456110503001 & $058-05.09 \times 05.82$ & Cow Springs & $1 \mathrm{~K}-225$ & 362456 & 1105030 \\
\hline 362647110243501 & 056-09.00x03.73 & Peabody 4 & --- & 362647 & 1102437 \\
\hline 362823109463101 & $054-01.41 \times 01.85$ & Rough Rock & 10R-119 & 362823 & 1094631 \\
\hline 362936109564101 & $054-10.96 \times 00.63$ & BM observation well 1 & $8 \mathrm{~T}-537$ & 362927 & 1095651 \\
\hline 363005110250901 & $039-09.44 \times 17.18$ & Peabody 2 & --- & 363005 & 1102509 \\
\hline 363013109584901 & $037-12.81 \times 16.98$ & Sweetwater Mesa & $8 \mathrm{~K}-443$ & 363013 & 1095849 \\
\hline 363103109445201 & $036-13.75 \times 16.01$ & Rough Rock & $9 Y-95$ & 363103 & 1094452 \\
\hline 363137110044702 & $038-04.43 \times 15.39$ & Chilchinbito PM3 & --- & 363137 & 1100447 \\
\hline 363143110355001 & $040-05.38 \times 15.27$ & BM observation well 4 & $2 \mathrm{~T}-514$ & 363141 & 1103554 \\
\hline 363213110342001 & $040-04.03 \times 14.68$ & Shonto Southeast & $2 \mathrm{~K}-301$ & 363213 & 1103420 \\
\hline 363232109465601 & $037-01.81 \times 14.35$ & Rough Rock & $9 Y-92$ & 363232 & 1094656 \\
\hline 363309110420501 & $040-11.20 \times 13.60$ & Shonto & $2 \mathrm{~K}-300$ & 363309 & 1104205 \\
\hline 363423110305501 & $040-00.85 \times 12.17$ & Shonto Southeast & $2 \mathrm{~T}-502$ & 363423 & 1103055 \\
\hline 363727110274501 & $039-11.83 \times 08.69$ & Long House Valley & $8 \mathrm{~T}-510$ & 363727 & 1102745 \\
\hline 363850110100801 & 038-09.40x07.08 & BM observation well 2 & $8 \mathrm{~T}-538$ & 363850 & 1101012 \\
\hline 364034110240001 & 039-08.31x05.09 & Marsh Pass & $8 \mathrm{~T}-522$ & 364034 & 1102400 \\
\hline 364226110171701 & $039-02.11 \times 02.94$ & Kayenta West & $8 \mathrm{~T}-541$ & 364226 & 1101717 \\
\hline 364248109514601 & $037-06.23 \times 02.51$ & Northeast Rough Rock & $8 \mathrm{~A}-180$ & 364248 & 1095146 \\
\hline 364338110154601 & 039-00.70x01.57 & BM observation well 3 & $8 \mathrm{~T}-500$ & 364338 & 1101545 \\
\hline 364344110151201 & $039-00.17 \times 01.45$ & Kayenta PM2 & 8A-295 & 364345 & 1101459 \\
\hline 365045109504001 & $022-05.23 \times 10.58$ & Dennehotso PM2 & $8 \mathrm{~K}-521$ & 365054 & 1095034 \\
\hline
\end{tabular}

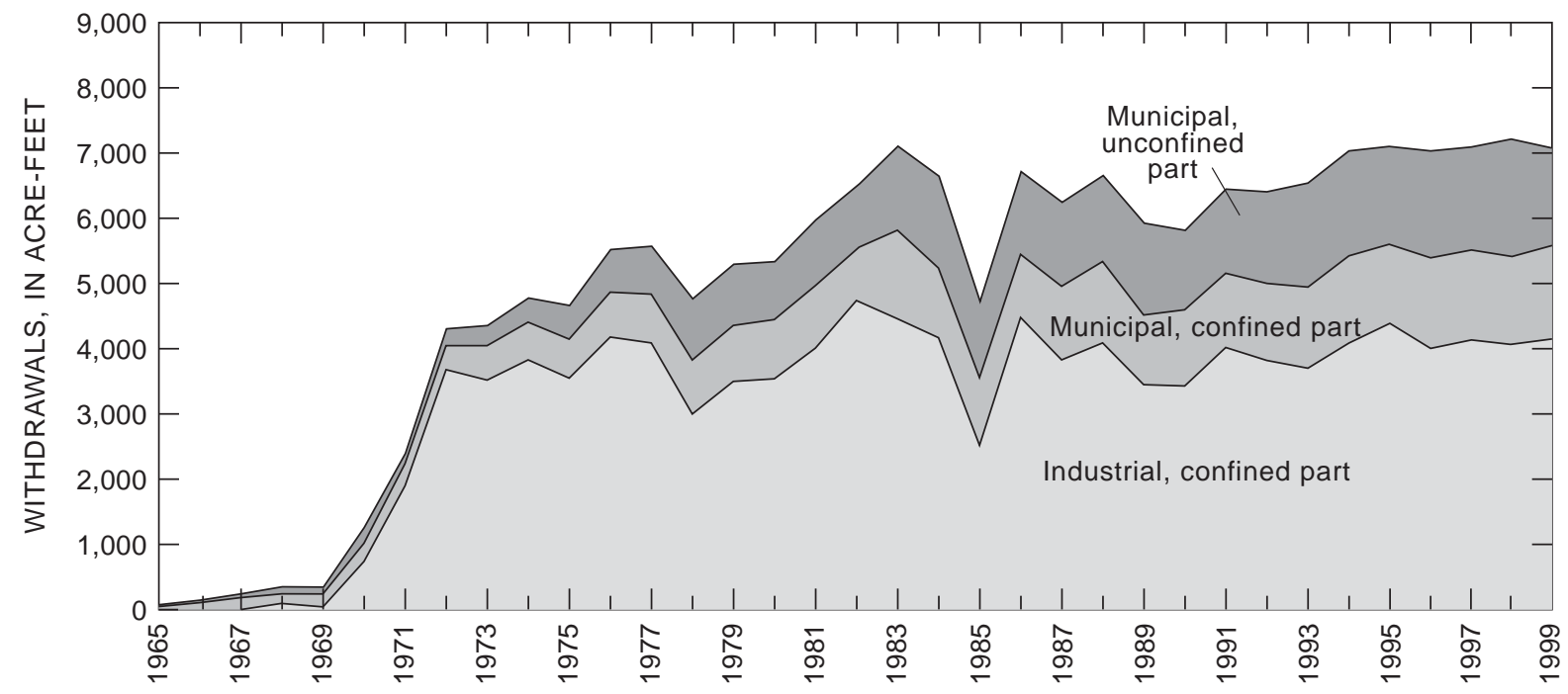

Figure 3. Withdrawals from the $\mathrm{N}$ aquifer, Black Mesa area, Arizona, 1965-99. 


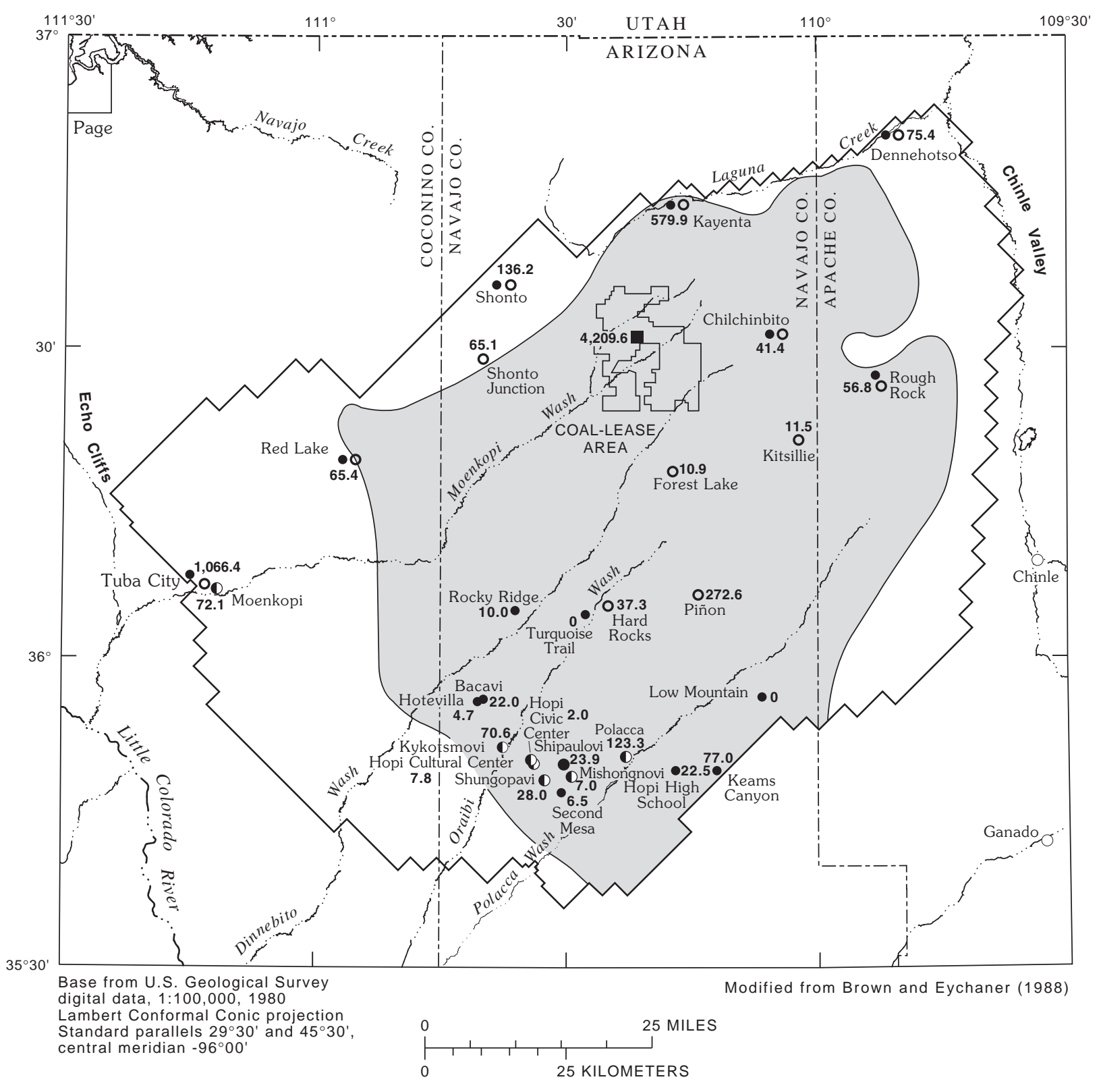

EXPLANATION

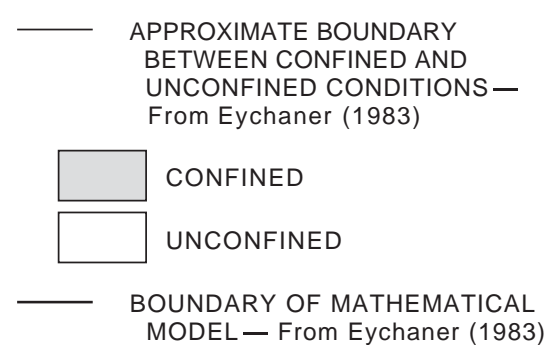
WELL-SYSTEM OWNER Hotevilla • WITHDRAWALS FROM THE N AQUIFER - Hotevilla, is the village name; 4.7 , is the total withdrawal in acre-feet for 1999. The total is cumulative at locations served
- Navajo Tribal Utility Authority by multiple well owners
- Hopi Tribe
- Peabody Western Coal Company

Figure 4. Location of well systems monitored for withdrawals from the N aquifer, Black Mesa area, Arizona, 1999. 
Table 3. Withdrawals from the $\mathrm{N}$ aquifer by well system, Black Mesa area, Arizona, 1999

[Withdrawals, in acre-feet, are from flowmeter measurements. BIA, Bureau of Indian Affairs; NTUA, Navajo Tribal Utility Authority; USGS, U.S. Geological Survey; Peabody, Peabody Western Coal Company; Hopi, Hopi Village Administrations; BIA Roads, Bureau of Indian Affairs, Division of Roads]

\begin{tabular}{|c|c|c|c|c|c|c|c|c|c|}
\hline \multirow[b]{2}{*}{$\begin{array}{c}\text { Well system } \\
\text { (one or more wells) }\end{array}$} & \multirow[b]{2}{*}{ Owner } & \multirow[b]{2}{*}{$\begin{array}{l}\text { Source of } \\
\text { data }\end{array}$} & \multicolumn{2}{|c|}{ Withdrawals } & \multirow[b]{2}{*}{$\begin{array}{c}\text { Well system } \\
\text { (one or more wells) }\end{array}$} & \multirow[b]{2}{*}{ Owner } & \multirow[b]{2}{*}{$\begin{array}{c}\text { Source of } \\
\text { data }\end{array}$} & \multicolumn{2}{|c|}{ Withdrawals } \\
\hline & & & $\begin{array}{l}\text { Confined } \\
\text { aquifer }\end{array}$ & $\begin{array}{l}\text { Unconfined } \\
\text { aquifer }\end{array}$ & & & & $\begin{array}{l}\text { Confined } \\
\text { aquifer }\end{array}$ & $\begin{array}{l}\text { Unconfine } \\
\text { d aquifer }\end{array}$ \\
\hline Chilchinbito & BIA & USGS/BIA & 6.8 & & Kayenta & NTUA & NTUA & 504.2 & \\
\hline Dennehotso & BIA & USGS/BIA & & 41.8 & Kitsillie & NTUA & NTUA & 11.5 & \\
\hline Hopi High School & BIA & USGS/BIA & 22.5 & & Piñon & NTUA & NTUA & 272.6 & \\
\hline Hotevilla & BIA & USGS/BIA & 4.7 & & Red Lake & NTUA & NTUA & & 57.8 \\
\hline Kayenta & BIA & USGS/BIA & 75.7 & & Rough Rock & NTUA & NTUA & 22.2 & \\
\hline Keams Canyon & BIA & USGS/BIA & 77.0 & & Shonto & NTUA & NTUA & & 16.4 \\
\hline Low Mountain & BIA & USGS/BIA & ${ }^{1} 0$ & & Shonto Junction & NTUA & NTUA & & 65.1 \\
\hline Piñon & BIA & USGS/BIA & ${ }^{1} 0$ & & Tuba City & NTUA & NTUA & & 872.3 \\
\hline Red Lake & BIA & USGS/BIA & & 7.6 & Mine Well Field & Peabody & Peabody & ${ }^{2} 4,209.6$ & \\
\hline Rocky Ridge & BIA & USGS/BIA & 11.3 & & Bacavi & Hopi & USGS/Hopi & 22.0 & \\
\hline Rough Rock & BIA & USGS/BIA & 34.6 & & Hopi Civic Center & Hopi & USGS/Hopi & 2.0 & \\
\hline Second Mesa & BIA & USGS/BIA & 6.5 & & $\begin{array}{l}\text { Hopi Cultural } \\
\text { Center }\end{array}$ & Hopi & USGS/Hopi & 7.8 & \\
\hline Shonto & BIA & USGS/BIA & & 119.8 & Kykotsmovi & Hopi & USGS/Hopi & 70.6 & \\
\hline Tuba City & BIA & USGS/BIA & & 194.1 & Mishongnovi & Hopi & USGS/Hopi & 7.0 & \\
\hline Turquoise Trail & BIA & BIA Roads & ${ }^{1} 0$ & & Moenkopi & Hopi & USGS/Hopi & & 72.1 \\
\hline Chilchinbito & NTUA & NTUA & 34.6 & & Polacca & Hopi & USGS/Hopi & ${ }^{3} 123.3$ & \\
\hline Dennehotso & NTUA & NTUA & & 33.6 & Shipaulovi & Hopi & USGS/Hopi & 23.9 & \\
\hline Forest Lake & NTUA & NTUA & 10.9 & & Shungopovi & Hopi & USGS/Hopi & 28.0 & \\
\hline Hard Rock & NTUA & NTUA & 37.3 & & & & & & \\
\hline
\end{tabular}

${ }^{1}$ Well taken out of service.

2 Industrial pumpage.

${ }^{3}$ Estimated. Well PM4 not metered. Pumpage from PM4 was estimated as 40 acre-feet on the basis of previous metered data and a per capita consumption of 40 gallons per day. Pumping from the remaining wells (PM5 and PM6) may include some water from the D aquifer.

Withdrawals from wells equipped with windmills are not measured in this monitoring program. About 270 windmills in the Black Mesa area withdraw water from the $\mathrm{D}$ and $\mathrm{N}$ aquifers, and estimated total withdrawals by the windmills are about 65 acre-ft/yr (HSIGeoTrans, Inc., and Waterstone Environmental Hydrology and Engineering, Inc., 1999). This amount is less than 1 percent of the total annual withdrawal from the $\mathrm{N}$ aquifer.

In 1999, the total ground-water withdrawal from the $\mathrm{N}$ aquifer was about 7,110 acre-ft (table 1), which is a 0.7-percent increase from the total withdrawal in 1998. Withdrawals for municipal use from the confined part of the aquifer were 1,420 acre- $\mathrm{ft}$, which is a 1-percent decrease from 1998. Withdrawals for municipal use from the unconfined part of the aquifer were 1,480 acre-ft, which is a 7-percent decrease. Withdrawals for industrial use were 4,210 acre-ft, which is a 4-percent increase from 1998.

Withdrawals from the $\mathrm{N}$ aquifer have been increasing since the 1970s (table 1, fig. 3). Total withdrawals increased from 1,170 acre-ft in 1970 to 4,300 acre- $\mathrm{ft}$ in 1972 when industrial use increased from 740 to 3,680 acre-ft. Since 1973, industrial use has fluctuated between 2,500 and 4,700 acre-ft/yr. Municipal use increased by about 20 percent per year during the 1970s, slowed to an increase of about 4 percent per year in the 1980 s, and slowed further to 
an increase of about 2 percent per year in the 1990s. From 1998 to 1999, industrial use increased by 4 percent, and municipal use decreased by 4 percent.

In the 1970s, industrial use was about 75 percent of the total withdrawal. With the increase in municipal use over the last 30 years, industrial use, as a percentage of total withdrawals, has declined to about 60 percent in the late 1990s.

During an evaluation of historical pumpage data, a mistake was discovered in the reported pumpage for the Tuba City NTUA wells. The NTUA records for 1991 had a misplaced decimal place for the meter readings at one well, which resulted in estimated withdrawal of 10 times greater than actual withdrawal for that well. In this report, therefore, the total municipal use for unconfined areas in 1991 was changed from 3,360 to 1,300 acre-ft, and total withdrawal was changed from 8,520 to 6,460 acre-ft

(table 1, fig. 3).

In an effort to improve and ensure accuracy of ground-water withdrawal data, a quality-assurance program was begun in 1985 for data from industrial and municipal wells completed in the $\mathrm{N}$ aquifer. Nearly all industrial and municipal wells in the study area are equipped with totalizing flowmeters to measure ground-water withdrawals. The flowmeters on the wells are tested about once every 5 years by measuring pumpage with a calibrated mechanical flowmeter and comparing the measured pumpage to the metered pumpage. For the purpose of this study, the allowable difference between the discharge measured by the permanent totalizing flowmeter and the test meter is 10 percent.

This flowmeter testing was performed on about half the municipal wells in 1998 and early 1999, and results from that testing are shown in Truini and others (2000). Most of the remaining municipal wells were tested in 1999, and those results are shown in this report. Some municipal wells were not tested in 1998 or 1999. Most of the untested wells had been taken out of service. At one well, the flowmeter could not be connected; and at one well, the pumpage exceeded the capacity of the test meter.

For this report, 25 municipal wells were tested using a calibrated Rockwell mechanical flowmeter. The test flowmeter was attached to the discharge bypass at each site, and the average was taken of three readings made after discharge stabilized. The flowmeter measurements then were compared to the meter readings of the permanent totalizing flowmeter (table 4). Twenty-four of the 25 tested wells had permanent flowmeter readings within the allowable 10-percent difference from the test flowmeter (table 4). The meters at one well had a difference of 12.2 percent.

\section{Ground-Water Levels in the $\mathbf{N}$ Aquifer}

Ground water in the $\mathrm{N}$ aquifer is under confined conditions in the central part of the study area and under unconfined or water-table conditions around the periphery (fig. 5). The ground water generally flows radially outward from recharge areas near Kayenta and Shonto to the southwest, south, southeast, and east (Lopes and Hoffmann, 1997).

Ground-water levels are measured each year of the Black Mesa monitoring program and compared with levels from previous years to determine changes over time. In 1999, water levels were measured in 31 wells that are used for observation, municipal supply, or stock supply (table 5). Six of the 31 wells are observation wells that were operated on a continuous basis; water levels were recorded daily. Water levels were measured manually twice a year in the six continuous- observation wells.

The wells used for water-level measurements are spread throughout the study area (fig. 5). Although all the wells are completed in the $\mathrm{N}$ aquifer, characteristics of the wells vary considerably. Construction dates range from 1935 to 1980 , depths range from 107 to $3,640 \mathrm{ft}$, and depths to the top of the $\mathrm{N}$ aquifer range from 0 to 2,530 ft (table 6).

From 1998 to 1999, water levels declined in 25 of 31 measured wells. The median water-level decline in the 31 wells was $0.8 \mathrm{ft}$. Changes ranged from a decline of $18.7 \mathrm{ft}$ in the Kykotsmovi PM1 well to a rise of $8.9 \mathrm{ft}$ in BM observation well 3 (table 5).

From 1998 to 1999 , water levels declined in 11 of 15 wells in unconfined areas. The median decline was $0.7 \mathrm{ft}$, and the changes ranged from $-4.9 \mathrm{ft}$ to $+0.3 \mathrm{ft}$. In confined areas, water levels declined in 14 of 16 wells. The median decline was $1.2 \mathrm{ft}$, and the changes ranged from $-18.7 \mathrm{ft}$ to $+8.9 \mathrm{ft}$ (table 5).

The rates of annual water-level changes for observation wells in unconfined and confined areas have not appreciably changed since 1983, and the changes from 1998 to 1999 were less than a 1-foot difference from the average annual median changes for 1983-99 (fig. 6). The median change of $-0.7 \mathrm{ft}$ from 1998 to 1999 in unconfined areas was a decline, but the average annual median change from 1983 to 1999 was a rise of $0.2 \mathrm{ft}$. The median decline of $1.2 \mathrm{ft}$ from 1998 to 1999 in confined areas was smaller than the average annual median decline of $1.9 \mathrm{ft}$. 
Table 4. Flowmeter-test results for municipal wells that are completed in the N aquifer, Black Mesa area, Arizona, 1999

\begin{tabular}{|c|c|c|c|c|c|}
\hline \multirow[b]{2}{*}{ Well name } & \multirow[b]{2}{*}{ Date tested } & \multicolumn{2}{|c|}{$\begin{array}{l}\text { Pumping rate, in gallons } \\
\text { per minute }\end{array}$} & \multirow{2}{*}{$\begin{array}{c}\text { Percent } \\
\text { difference }^{2}\end{array}$} & \multirow{2}{*}{$\begin{array}{l}\text { Name and number } \\
\text { of permanent meter }\end{array}$} \\
\hline & & Permanent meter & Test meter ${ }^{1}$ & & \\
\hline \multicolumn{6}{|c|}{ Navajo Tribal Utility Authority (NTUA) } \\
\hline Chilchinbito 1 & 05-18-99 & 48 & 47 & +2.1 & Rockwell 1175064 \\
\hline Chilchinbito 2 & 05-18-99 & 60 & 59 & +1.7 & Rockwell 1236134 \\
\hline Dennehotso 1 & 05-18-99 & 71 & 68 & +4.4 & Rockwell 3344700 \\
\hline Dennehotso 2 & 05-18-99 & 96 & 97 & -1.0 & Rockwell 1306471 \\
\hline Forest Lake & $05-18-99$ & 55 & 49 & +12.2 & Hersey 6049985 \\
\hline Hard Rock 1 & 06-10-99 & 118 & 119 & -0.8 & Brooks 8405-24272-1-1 \\
\hline Hard Rock 2 & $\left({ }^{3}\right)$ & $\left({ }^{3}\right)$ & $\left({ }^{3}\right)$ & $\left({ }^{3}\right)$ & $\left({ }^{3}\right)$ \\
\hline Kayenta 1 & 05-25-99 & 121 & 123 & -1.6 & Sensus 1541749 \\
\hline Kayenta 6 & 01-07-99 & 148 & 146 & +1.4 & Sensus 1412051 \\
\hline Kayenta 7 & $05-25-99$ & 101 & 92 & +9.8 & Sensus 1436356 \\
\hline Kitsillie 1 & 05-19-99 & 44 & 41 & +7.3 & Sensus 52139870 \\
\hline Kitsillie 2 & 05-19-99 & 75 & 79 & -5.1 & Sensus 1451526 \\
\hline Piñon 1 & 05-19-99 & 95 & 98 & -3.1 & Sensus 1442466 \\
\hline Piñon 2 & 05-19-99 & 123 & 119 & +3.4 & Sensus 1432493 \\
\hline Rough Rock 1 & 05-19-99 & 32 & 32 & 0 & Rockwell 1320677 \\
\hline Rough Rock 2 & 05-19-99 & 82 & 84 & -2.4 & Sensus 1329324 \\
\hline \multicolumn{6}{|c|}{ Bureau of Indian Affairs (BIA) } \\
\hline Chilchinbito PM3 & 05-09-99 & 24 & 24 & 0 & Precision P521349 \\
\hline Kayenta 2 & 05-17-99 & 111 & 110 & +0.9 & Neptune 31973644 \\
\hline Kayenta 3 & 05-26-99 & 150 & 153 & -2.0 & Rockwell 1305841 \\
\hline Piñon PM6 & $\left({ }^{4}\right)$ & $\left({ }^{4}\right)$ & $\left({ }^{4}\right)$ & $\left({ }^{4}\right)$ & $\left({ }^{4}\right)$ \\
\hline Red Lake PM1 & $05-17-99$ & 47 & 46 & +2.2 & Master Meter 1365600 \\
\hline Red Lake PM2 & $\left({ }^{5}\right)$ & $\left({ }^{5}\right)$ & $\left({ }^{5}\right)$ & $\left({ }^{5}\right)$ & $\left({ }^{5}\right)$ \\
\hline Rocky Ridge & 06-09-99 & 52 & 52 & 0 & Rockwell 1331029 \\
\hline Rough Rock PM3 & 05-26-99 & 50 & 50 & 0 & Rockwell 36880399 \\
\hline Rough Rock PM5 & 05-26-99 & 38 & 38 & 0 & Rockwell 36726380 \\
\hline Rough Rock PM7 & $\left({ }^{6}\right)$ & $\left({ }^{6}\right)$ & $\left({ }^{6}\right)$ & $\left({ }^{6}\right)$ & $\left({ }^{6}\right)$ \\
\hline Shonto PM2 & 05-17-99 & 167 & 169 & -1.2 & Rockwell 1255896 \\
\hline Shonto PM3 & 05-17-99 & 93 & 91 & +2.2 & Rockwell 1300477 \\
\hline Shonto PM4 & 05-17-99 & 73 & 72 & +1.4 & Sensus 1325584 \\
\hline
\end{tabular}




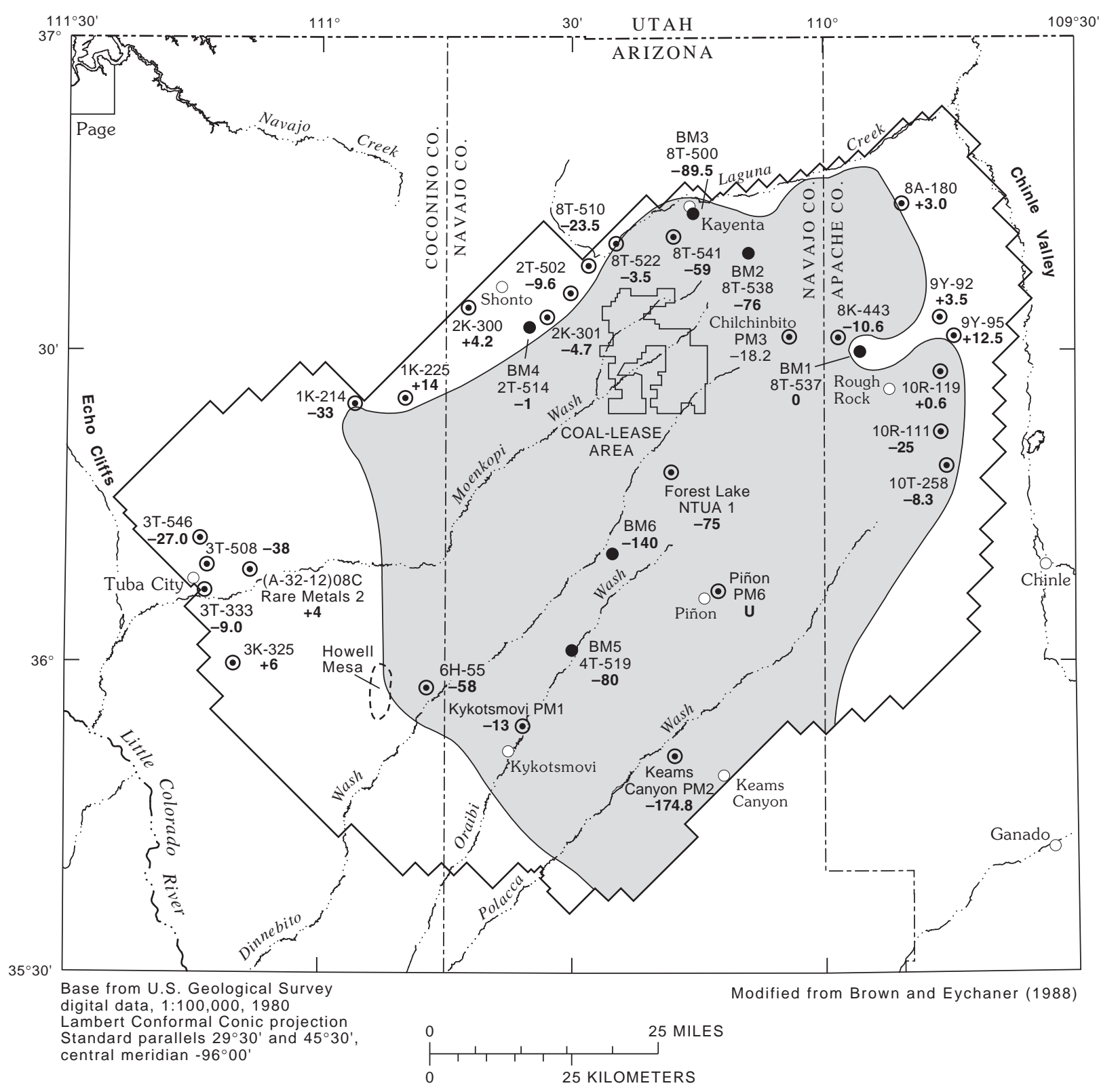

\section{EXPLANATION}

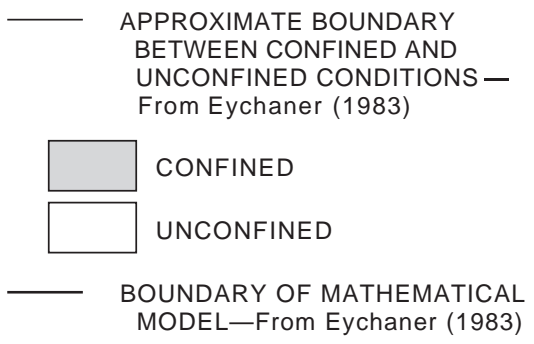

$\begin{array}{cc}\odot & \text { WELL IN WHICH DEPTH TO } \\ 6 \mathrm{H}-55 & \text { WATER WAS MEASURED } \\ \mathbf{- 5 8} & \text { ANNUALLY - First entry, } \\ & \text { 6H-55, is Bureau of Indian } \\ & \text { Affairs site number; second } \\ & \text { entry, -58, is change in } \\ & \text { water level, in feet, between } \\ \text { measurement made during } & \text { the prestress period and } \\ & \text { measurement made during } \\ & \text { 1999. U, unable to measure }\end{array}$

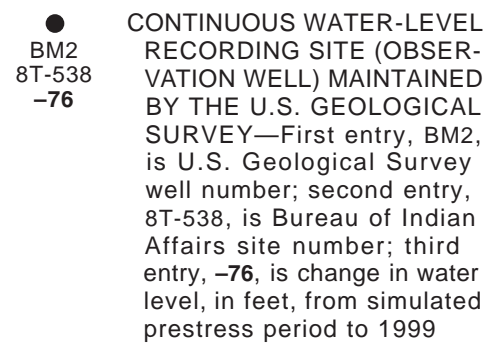

Figure 5. Water-level changes in N-aquifer wells from the prestress period to 1999, Black Mesa area, Arizona. See table $\mathbf{5}$. 
Table 5. Water-level changes in wells completed in the $\mathrm{N}$ aquifer, Black Mesa area, Arizona, prestress period to 1999 [Dashes indicate no data. Do., ditto; P, recently pumped; R, reported]

\begin{tabular}{|c|c|c|c|c|c|c|c|}
\hline \multirow[b]{2}{*}{ Common name or location } & \multirow[b]{2}{*}{$\begin{array}{l}\text { Bureau of Indian } \\
\text { Affairs site number }\end{array}$} & \multicolumn{2}{|c|}{$\begin{array}{l}\text { Change in water level } \\
\text { from preceding year, } \\
\text { in feet }\end{array}$} & \multirow{2}{*}{$\begin{array}{c}\text { Water level, } \\
\text { in feet below } \\
\text { land surface, } \\
1999\end{array}$} & \multicolumn{2}{|c|}{$\begin{array}{l}\text { Prestress period } \\
\text { water level }^{1}\end{array}$} & \multirow{2}{*}{$\begin{array}{c}\text { Change in } \\
\text { water level } \\
\text { from prestress } \\
\text { period to } 1999 \\
\text { in feet }\end{array}$} \\
\hline & & 1998 & 1999 & & $\begin{array}{l}\text { land } \\
\text { surface }\end{array}$ & Date & \\
\hline \multicolumn{8}{|c|}{ Unconfined area } \\
\hline BM observation well $1^{2}$ & $8 \mathrm{~T}-537$ & -0.3 & 0.0 & 374.2 & 374 & $\left({ }^{2}\right)$ & 0 \\
\hline BM observation well $4^{2}$ & $2 \mathrm{~T}-514$ & -0.3 & -1.0 & 217.3 & ${ }^{3} 216$ & $\left({ }^{2}\right)$ & -1 \\
\hline Cow Springs & $1 \mathrm{~K}-225$ & +1.2 & 0.0 & 45.8 & 60 & 07-04-54 & +14 \\
\hline Long House Valley & $8 \mathrm{~T}-510$ & -1.5 & -0.9 & 122.9 & 99.4 & $08-22-67$ & -23.5 \\
\hline Northeast Rough Rock & $8 \mathrm{~A}-180$ & -0.1 & -0.7 & 43.9 & 46.9 & $11-13-53$ & +3.0 \\
\hline Rough Rock & $9 Y-95$ & +7.8 & +0.3 & 107.0 & 119.5 & 08-03-49 & +12.5 \\
\hline Do. & $9 Y-92$ & +1.4 & -0.5 & 165.3 & 168.8 & $12-31-52$ & +3.5 \\
\hline Shonto & $2 \mathrm{~K}-300$ & ${ }^{4}+0.3$ & -0.8 & 172.3 & 176.5 & $06-13-50$ & +4.2 \\
\hline Shonto Southeast & $2 \mathrm{~K}-301$ & -0.8 & -0.4 & 288.6 & 283.9 & $12-10-52$ & -4.7 \\
\hline Do. & 2T-502 & +2.6 & -0.9 & 415.4 & 405.8 & $08-22-67$ & -9.6 \\
\hline Tuba City & $3 \mathrm{~T}-333$ & -1.5 & -1.2 & 32.0 & 23.0 & $12-02-55$ & -9.0 \\
\hline Do. & $3 \mathrm{~K}-325$ & +0.5 & -0.5 & 202.0 & 208 & $06-30-55$ & +6 \\
\hline Tuba City Rare Metals 2 & --- & +0.1 & 0.0 & 52.6 & 57 & 09-24-55 & +4 \\
\hline Tuba NTUA 1 & 3T-508 & $4-3.4$ & -4.9 & 67.2 & 29 & $02-12-69$ & -38 \\
\hline Tuba NTUA 4 & $3 \mathrm{~T}-546$ & $\left({ }^{5}\right)$ & -0.8 & 60.7 & 33.7 & 08-06-71 & -27.0 \\
\hline \multicolumn{8}{|c|}{ Confined area } \\
\hline BM observation well $2^{2}$ & $8 \mathrm{~T}-538$ & -2.4 & -1.3 & 201.5 & 125 & $\left({ }^{2}\right)$ & -76 \\
\hline BM observation well $3^{2}$ & $8 \mathrm{~T}-500$ & -3.8 & +8.9 & 144.5 & 355.0 & $04-29-63$ & -89.5 \\
\hline BM observation well $5^{2}$ & $4 \mathrm{~T}-519$ & -3.0 & -3.3 & 404.1 & 324 & $\left({ }^{2}\right)$ & -80 \\
\hline BM observation well $6^{2}$ & --- & -3.2 & -7.4 & 836.7 & ${ }^{3} 697$ & $\left({ }^{2}\right)$ & -140 \\
\hline Chilchinbito PM3 & --- & $\left({ }^{5}\right)$ & ${ }^{4}+0.8$ & 423.5 & 405.3 & $09-25-65$ & -18.2 \\
\hline Forest Lake NTUA 1 & $4 \mathrm{~T}-523$ & -5.4 & -4.8 & $1,171.3 \mathrm{P}$ & $1,096 \mathrm{R}$ & $05-21-82$ & -75 \\
\hline Howell Mesa & $6 \mathrm{H}-55$ & $\left({ }^{5}\right)$ & $4-1.0$ & 270.2 & 212 & $07-08-54$ & -58 \\
\hline Kayenta West & $8 \mathrm{~T}-541$ & -6.4 & -1.6 & 286.4 & 227 & $07-17-79$ & -59 \\
\hline Keams Canyon PM2 & --- & $4-10.1$ & -4.5 & 467.3 & 292.5 & 06-10-70 & -174.8 \\
\hline Kykotsmovi PM1 & --- & $4+22.0$ & -18.7 & 232.9 & 220 & $05-20-67$ & -13 \\
\hline Marsh Pass ${ }^{6}$ & $8 \mathrm{~T}-522$ & -0.5 & -0.6 & 129.0 & 125.5 & $02-07-72$ & -3.5 \\
\hline Piñon PM6 & --- & -5.0 & $\left({ }^{5}\right)$ & $\left(5^{5}\right)$ & 743.6 & $05-28-70$ & $\left({ }^{5}\right)$ \\
\hline Rough Rock & 10R-119 & 0 & -0.8 & 256.0 & 256.6 & $12-02-52$ & +0.6 \\
\hline Do. & $10 \mathrm{~T}-258$ & +5.8 & -0.5 & 309.3 & 301.0 & $04-14-60$ & -8.3 \\
\hline Do. & 10R-111 & +0.1 & -4.0 & 195.0 & 170 & 08-04-54 & -25 \\
\hline Sweetwater Mesa & $8 \mathrm{~K}-443$ & $4-0.9$ & -0.4 & 540.0 & 529.4 & $09-26-67$ & -10.6 \\
\hline White Mesa $\operatorname{Arch}^{6}$ & $1 \mathrm{~K}-214$ & -0.5 & -0.3 & 220.6 & 188 & 06-04-53 & -33 \\
\hline $\begin{array}{l}\text { 1Prestress refers to the period of rec } \\
\text { measurement before 1965, the earliest } \\
{ }^{2} \text { Continuous recorder. Except for w } \\
{ }^{3} \text { Prestress water levels for indicated } \\
1998 \text { report and } 60 \text { feet in } 1995-97 \text { rep } \\
{ }^{4} \text { Change in water level from last me } \\
{ }^{5} \text { Water level not measured because } \\
{ }^{6} \text { Classification of well changed fron }\end{array}$ & $\begin{array}{l}\text { before appreciable grounc } \\
\text { r-level measurement is sh } \\
\text { M3, prestress water level } \\
\text { ls were changed from pre } \\
\text { BM4 was } 217 \text { feet, and E } \\
\text { ement } 2 \text { to } 4 \text { years earlier } \\
\text { struction in well, no acce } \\
\text { confined area in previous }\end{array}$ & $\begin{array}{l}16 \text { was } 73 \text {. } \\
\text { to well, or }\end{array}$ & $\begin{array}{l}\text { s for mining } \\
\text { om the grour } \\
\text { monitoring re } \\
\text { et in 1995-98 } \\
\text { isited. }\end{array}$ & $\begin{array}{l}\text { or municipal purpos } \\
\text { d-water model by B } \\
\text { orts to more accurc } \\
\text { reports. }\end{array}$ & $\begin{array}{l}\text {-about } 1965 . \\
\text { vn and Eycha } \\
\text { y represent pr }\end{array}$ & $\begin{array}{l}\text { wells that had } \mathrm{r} \\
\text { 1988). } \\
\text { ss conditions. I }\end{array}$ & $\begin{array}{l}\text { o water-level } \\
\text { M3 was } 77.1 \text { feet in }\end{array}$ \\
\hline
\end{tabular}


Table 6. Well-construction characteristics, top of $\mathrm{N}$ aquifer, and type of data collected for study wells, Black Mesa area, Arizona, 1999

\begin{tabular}{|c|c|c|c|c|c|c|}
\hline $\begin{array}{c}\text { Bureau of Indian Affairs site number } \\
\text { or common name }\end{array}$ & $\begin{array}{l}\text { Date well } \\
\text { was } \\
\text { completed }\end{array}$ & $\begin{array}{l}\text { Land- } \\
\text { surface } \\
\text { altitude, } \\
\text { in feet }\end{array}$ & $\begin{array}{c}\text { Well } \\
\text { depth, } \\
\text { in feet } \\
\text { below } \\
\text { land } \\
\text { surface }\end{array}$ & $\begin{array}{c}\text { Screened/open } \\
\text { interval(s), in feet below } \\
\text { land surface }\end{array}$ & $\begin{array}{l}\text { Depth to top } \\
\text { of } N \text { aquifer, } \\
\text { in feet } \\
\text { below land } \\
\text { surface }^{1}\end{array}$ & $\begin{array}{c}\text { Type of data } \\
\text { collected in } 1999\end{array}$ \\
\hline 8T-537 (BM observation well 1) & $02-01-72$ & 5,864 & 850 & $\begin{array}{c}300-360 ; 400-420 \\
500-520 ; 600-620 \\
730-780\end{array}$ & 290 & Water level \\
\hline 8T-538 (BM observation well 2) & $01-29-72$ & 5,656 & 1,338 & $470-1,338$ & 452 & Water level \\
\hline 8T-500 (BM observation well 3) & $07-29-59$ & 5,724 & 868 & $712-868$ & 155 & Water level \\
\hline 2T-514 (BM observation well 4) & $02-15-72$ & 6,320 & 400 & $250-400$ & 160 & Water level \\
\hline 4T-519 (BM observation well 5) & $02-25-72$ & 5,869 & 1,683 & $1,521-1,683$ & 1,520 & Water level \\
\hline BM observation well 6 & $01-31-77$ & 6,332 & 2,507 & $1,954-2,506$ & 1,950 & Water level \\
\hline $1 \mathrm{~K}-214$ & $05-26-50$ & 5,771 & 356 & $168-356$ & 250 & Water level \\
\hline $1 \mathrm{~K}-225$ & $07-04-54$ & 5,722 & 251 & $19-251$ & ${ }^{2} 10$ & Water level \\
\hline $2 \mathrm{~K}-300$ & ${ }^{3} 06-00-50$ & 6,264 & 300 & $260-300$ & 0 & Water level \\
\hline $2 \mathrm{~K}-301$ & $06-12-50$ & 6,435 & 500 & $\begin{array}{l}318-328 \\
378-500\end{array}$ & 230 & Water level \\
\hline $2 \mathrm{~T}-502$ & $08-10-59$ & 6,670 & 523 & $12-523$ & 25 & Water level \\
\hline $3 \mathrm{~K}-325$ & $06-01-55$ & 5,250 & 450 & $75-450$ & 230 & Water level \\
\hline $3 \mathrm{~T}-333$ & $12-02-55$ & 4,940 & 229 & $63-229$ & 24 & Water level \\
\hline $3 \mathrm{~T}-508$ & 08-25-99 & 5,119 & 475 & $\left({ }^{4}\right)$ & 0 & $\begin{array}{l}\text { Water level, } \\
\text { withdrawals }\end{array}$ \\
\hline $3 \mathrm{~T}-546$ & ${ }^{3} 08-00-71$ & 5,206 & 612 & $256-556$ & 0 & $\begin{array}{l}\text { Water level, } \\
\text { withdrawals }\end{array}$ \\
\hline $4 \mathrm{~T}-523$ & $10-01-80$ & 6,654 & 2,674 & $\begin{array}{l}1,870-1,910 \\
2,070-2,210 \\
2,250-2,674\end{array}$ & $\left({ }^{5}\right)$ & $\begin{array}{l}\text { Water level, } \\
\text { water quality, } \\
\text { withdrawals }\end{array}$ \\
\hline $6 \mathrm{H}-55$ & $12-08-44$ & 5,635 & 361 & $310-335$ & 310 & Water level \\
\hline $8 \mathrm{~A}-180$ & $01-20-39$ & 5,200 & 107 & 60-107 & 240 & Water level \\
\hline 8A-295 & ${ }^{3} 00-00-36$ & 5,623 & 840 & $\begin{array}{l}268-280 \\
691-788\end{array}$ & 95 & $\begin{array}{l}\text { Water quality, } \\
\text { withdrawals }\end{array}$ \\
\hline $8 \mathrm{~K}-443$ & $08-15-57$ & 6,024 & 720 & $619-720$ & 590 & Water level \\
\hline $8 \mathrm{~K}-521$ & $06-05-64$ & 5,005 & 675 & $475-675$ & ${ }^{2} 5$ & $\begin{array}{l}\text { Water quality, } \\
\text { withdrawals }\end{array}$ \\
\hline $8 \mathrm{~T}-510$ & $02-11-63$ & 6,262 & 314 & $130-314$ & ${ }^{2} 125$ & Water level \\
\hline $8 \mathrm{~T}-522$ & ${ }^{3} 07-00-63$ & 6,040 & 933 & 180-933 & 480 & Water level \\
\hline $8 \mathrm{~T}-541$ & $03-17-76$ & 5,885 & 890 & $740-890$ & 700 & Water level \\
\hline 9Y-92 & $01-02-39$ & 5,615 & 300 & $154-300$ & ${ }^{2} 50$ & Water level \\
\hline
\end{tabular}


Table 6. Well-construction characteristics, top of $\mathrm{N}$ aquifer, and type of data collected for study wells, Black Mesa area, Arizona, 1999-Continued

\begin{tabular}{|c|c|c|c|c|c|c|}
\hline $\begin{array}{c}\text { Bureau of Indian Affairs site number } \\
\text { or common name }\end{array}$ & $\begin{array}{l}\text { Date well } \\
\text { was } \\
\text { completed }\end{array}$ & $\begin{array}{l}\text { Land- } \\
\text { surface } \\
\text { altitude, } \\
\text { in feet }\end{array}$ & $\begin{array}{c}\text { Well } \\
\text { depth, } \\
\text { in feet } \\
\text { below } \\
\text { land } \\
\text { surface }\end{array}$ & $\begin{array}{l}\text { Screened/open } \\
\text { interval(s), in feet below } \\
\text { land surface }\end{array}$ & $\begin{array}{l}\text { Depth to top } \\
\text { of } \mathrm{N} \text { aquifer, } \\
\text { in feet } \\
\text { below land } \\
\text { surface }^{1}\end{array}$ & $\begin{array}{c}\text { Type of data } \\
\text { collected in } 1999\end{array}$ \\
\hline $9 Y-95$ & $11-05-37$ & 5,633 & 300 & $145-300$ & ${ }^{2} 68$ & Water level \\
\hline 10R-111 & $04-11-35$ & 5,757 & 360 & $267-360$ & 210 & Water level \\
\hline 10R-119 & 01-09-35 & 5,775 & 360 & $\left({ }^{4}\right)$ & 310 & Water level \\
\hline $10 \mathrm{~T}-258$ & $04-12-60$ & 5,903 & 670 & $465-670$ & 460 & Water level \\
\hline Chilchinbito PM3 & $09-25-65$ & 5,950 & 1,600 & $1,140-1,570$ & 1,136 & $\begin{array}{l}\text { Water level, } \\
\text { withdrawals }\end{array}$ \\
\hline Keams Canyon PM2 & ${ }^{3} 05-00-70$ & 5,809 & 1,106 & $906-1,106$ & 900 & $\begin{array}{l}\text { Water level, } \\
\text { water quality, } \\
\text { withdrawals }\end{array}$ \\
\hline Kitsillie NTUA 2 & $11-09-93$ & 6,780 & 2,620 & $\begin{array}{l}2,217-2,223 \\
2,240-2,256 \\
2,314-2,324 \\
2,344-2,394 \\
2,472-2,527\end{array}$ & 2,205 & $\begin{array}{l}\text { Water quality, } \\
\text { withdrawals }\end{array}$ \\
\hline Kykotsmovi PM1 & $02-20-67$ & 5,657 & 995 & $\begin{array}{l}655-675 \\
890-990\end{array}$ & 880 & $\begin{array}{l}\text { Water level, } \\
\text { withdrawals }\end{array}$ \\
\hline Kykotsmovi PM2 & $10-14-77$ & 5,717 & 1,160 & $950-1,160$ & 890 & $\begin{array}{l}\text { Water quality, } \\
\text { withdrawals }\end{array}$ \\
\hline Kykotsmovi PM3 & $08-07-68$ & 5,618 & 1,220 & $850-1,220$ & 840 & $\begin{array}{l}\text { Water quality, } \\
\text { withdrawals }\end{array}$ \\
\hline Piñon PM6 & ${ }^{3} 02-00-70$ & 6,359 & 2,248 & $1,895-2,243$ & 1,870 & $\begin{array}{l}\text { Water level, } \\
\text { withdrawals }\end{array}$ \\
\hline Peabody 2 & ${ }^{3} 06-00-67$ & 6,530 & 3,640 & $1,816-3,629$ & 2,530 & $\begin{array}{l}\text { Water quality, } \\
\text { withdrawals }\end{array}$ \\
\hline Peabody 4 & ${ }^{3} 05-00-68$ & 6,229 & 3,535 & $2,029-3,458$ & 2,280 & $\begin{array}{l}\text { Water quality, } \\
\text { withdrawals }\end{array}$ \\
\hline Red Lake PM1 & ${ }^{3} 09-00-57$ & 5,616 & 550 & $150-510$ & 120 & $\begin{array}{l}\text { Water quality, } \\
\text { withdrawals }\end{array}$ \\
\hline Rocky Ridge PM2 & $06-26-63$ & 5,985 & 1,780 & $1,480-1,780$ & 1,442 & $\begin{array}{l}\text { Water level, } \\
\text { water quality, } \\
\text { withdrawals }\end{array}$ \\
\hline Rough Rock PM5 & $06-27-64$ & 6,299 & 1,420 & $1,180-1,420$ & 1,156 & $\begin{array}{l}\text { Water quality, } \\
\text { withdrawals }\end{array}$ \\
\hline Tuba City Rare Metals 2 & ${ }^{3} 09-00-55$ & 5,108 & 705 & $100-705$ & 255 & Water level \\
\hline
\end{tabular}

1Depth to top of N aquifer from Eychaner (1983) and Brown and Eychaner (1988).

${ }^{2}$ All material between land surface and top of the $\mathrm{N}$ aquifer is unconsolidated-soil, alluvium, or dune sand.

${ }^{3} 00$, indicates month or day is unknown.

${ }^{4}$ Screened and (or) open intervals are unknown.

${ }^{5}$ Top of $\mathrm{N}$ aquifer was not estimated.

${ }^{6}$ Water level was not measured in 1999 


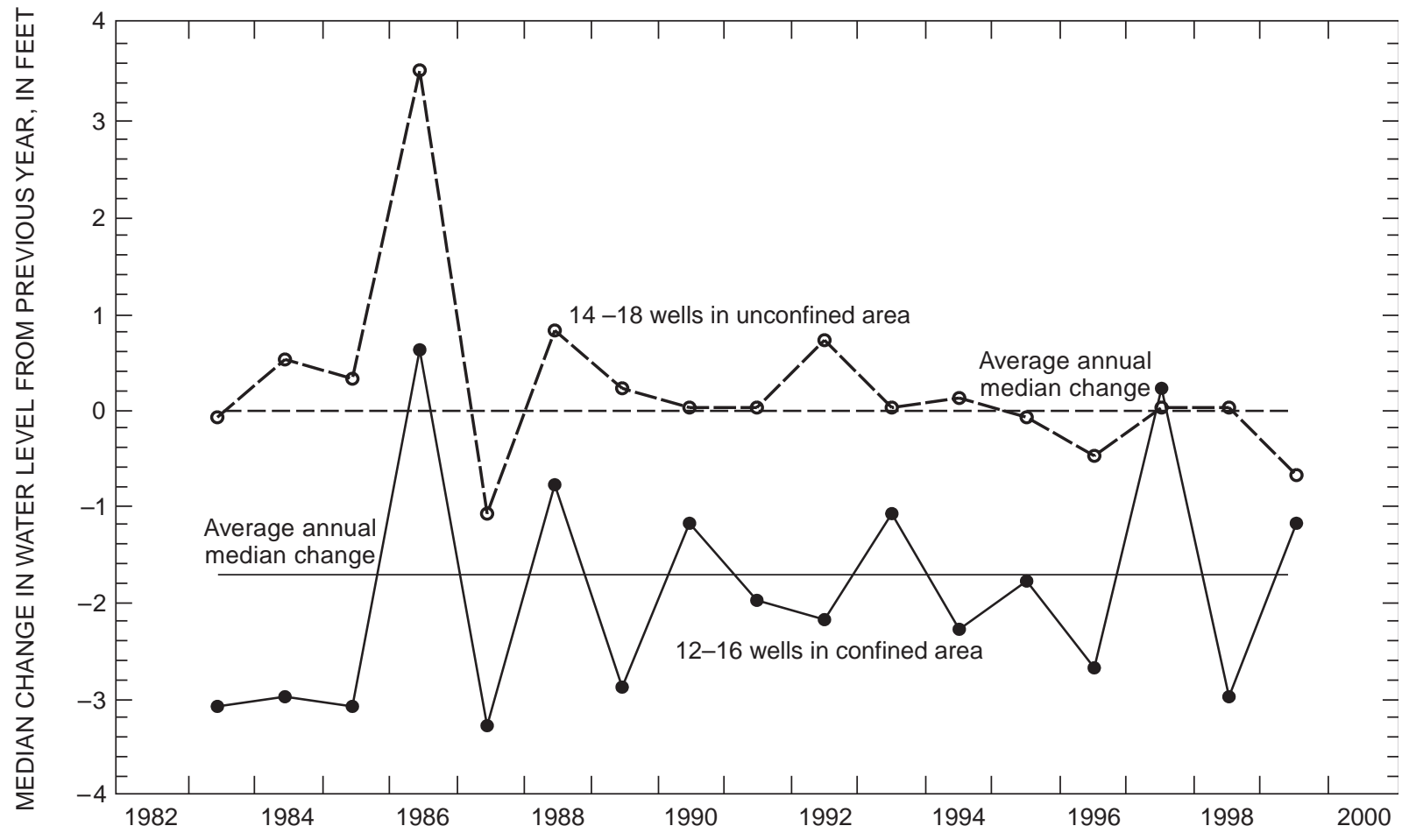

Figure 6. Rates of annual water-level changes for observation wells completed in the $\mathrm{N}$ aquifer, Black Mesa area, Arizona, 1983-99.

From the prestress period (prior to 1965) to 1999 , the median water-level decline in 31 wells was $10.6 \mathrm{ft}$. Water levels in 15 unconfined wells had a median change of $0.0 \mathrm{ft}$ and ranged from a 38 -foot decline to a 14-foot rise (table 5). Water levels in 16 confined wells had a median decline of $45.5 \mathrm{ft}$ and ranged from a decline of $174.8 \mathrm{ft}$ to a rise of $0.6 \mathrm{ft}$.

Hydrographs of water levels in wells in the annual observation network show the time trends of changes since about 1970 or 1980 (fig. 7). Water levels have changed only slightly in wells in unconfined areas. In contrast, water levels in wells in confined areas are more variable. In some wells, large declines occurred, and, in other wells, only small changes occurred.

Hydrographs for the Black Mesa observation wells show continuous water-level changes since about 1972 (fig. 8). Water levels in the two wells in unconfined areas (BM1 and BM4) have had small seasonal or yearto-year variation and have had small long-term changes since 1972. Water levels in the four wells in confined areas also have had little seasonal variation (except BM3); however, the water levels have consistently declined in all the confined wells since 1972.
In the mid-1990s, water levels were measured annually in 36 wells. In 1999, only 31 wells were measured; four wells were removed from the monitoring program and one well (Piñon PM6) could not be measured because access was not available. Wells, 3A-28, 3K-311, and Kykotsmovi PM3, have permanent obstructions that prevent measurements. The well, Rocky Ridge PM2, has anomalous waterlevel data for 1997-2000 that are assumed to be nonrepresentative of water levels in the $\mathrm{N}$ aquifer. The water levels for Rocky Ridge PM2 for 1997-2000 are 90 to $200 \mathrm{ft}$ higher than the levels for the previous 10 years (1987-96). From 1996 to 1997, the water level in the well rose $146 \mathrm{ft}$. That increase is not physically possible in the natural $\mathrm{N}$-aquifer system in Black Mesa. Because there have been no construction changes to the open interval of the well and there is no known physical evidence for the water-level increase, the most likely cause of the increase in water levels is a break in the well casing that would allow water from higher formations to enter the well. 
CONFINED AREA
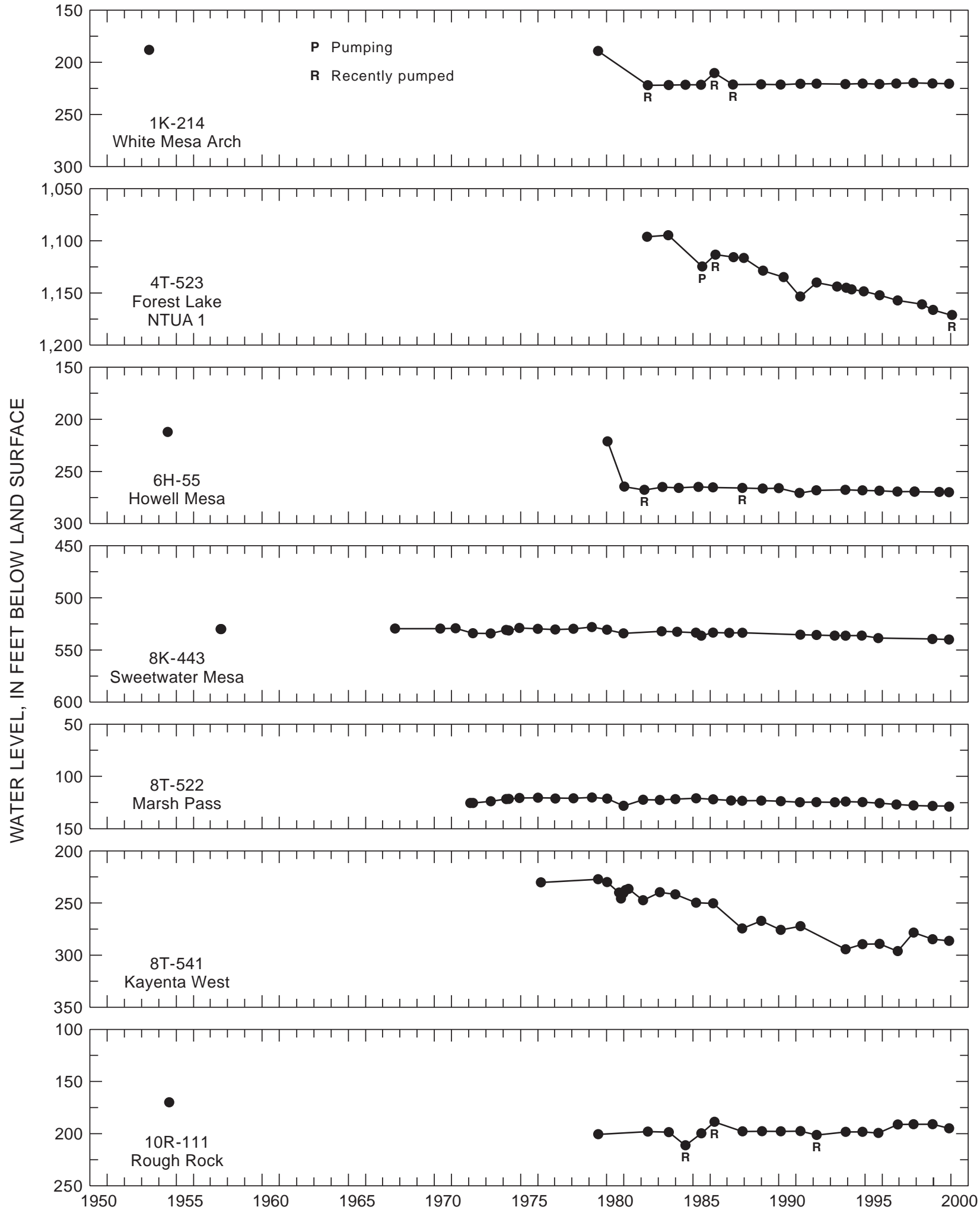

Figure 7. Water-level changes in wells used for annual water-level measurements, Black Mesa area, Arizona, 1950-2000. 
CONFINED AREA

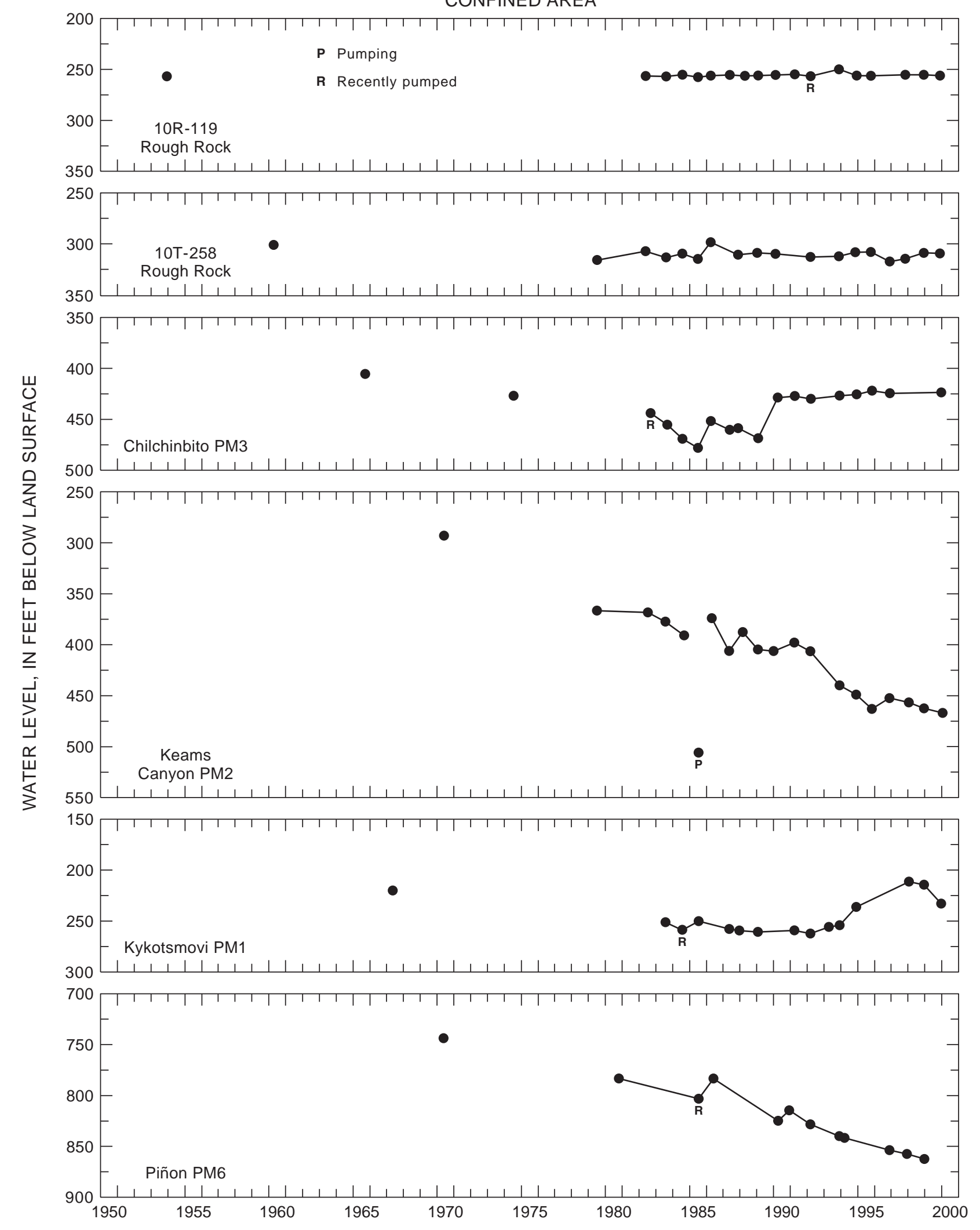

Figure 7. Continued. 
UNCONFINED AREA

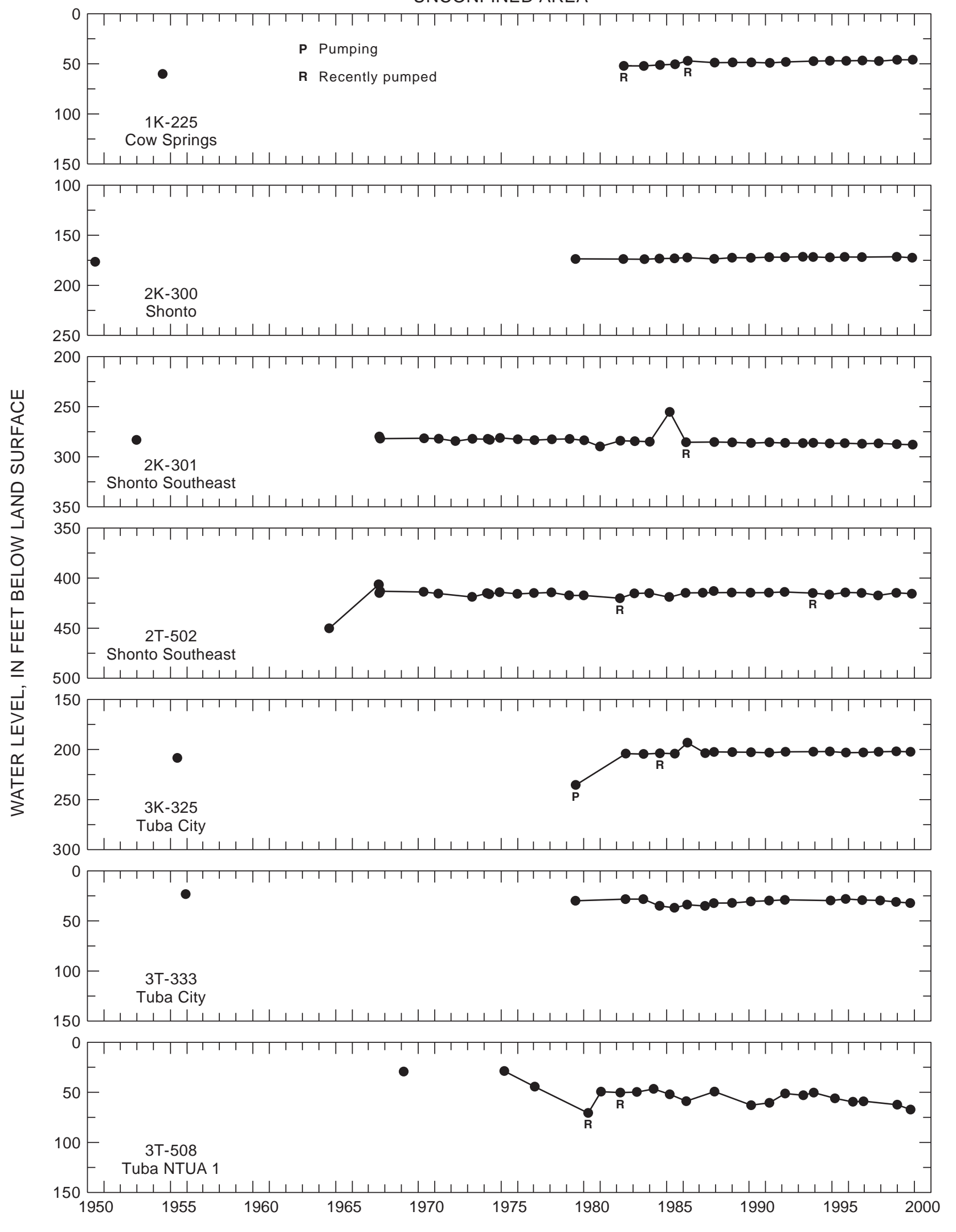

Figure 7. Continued. 
UNCONFINED AREA

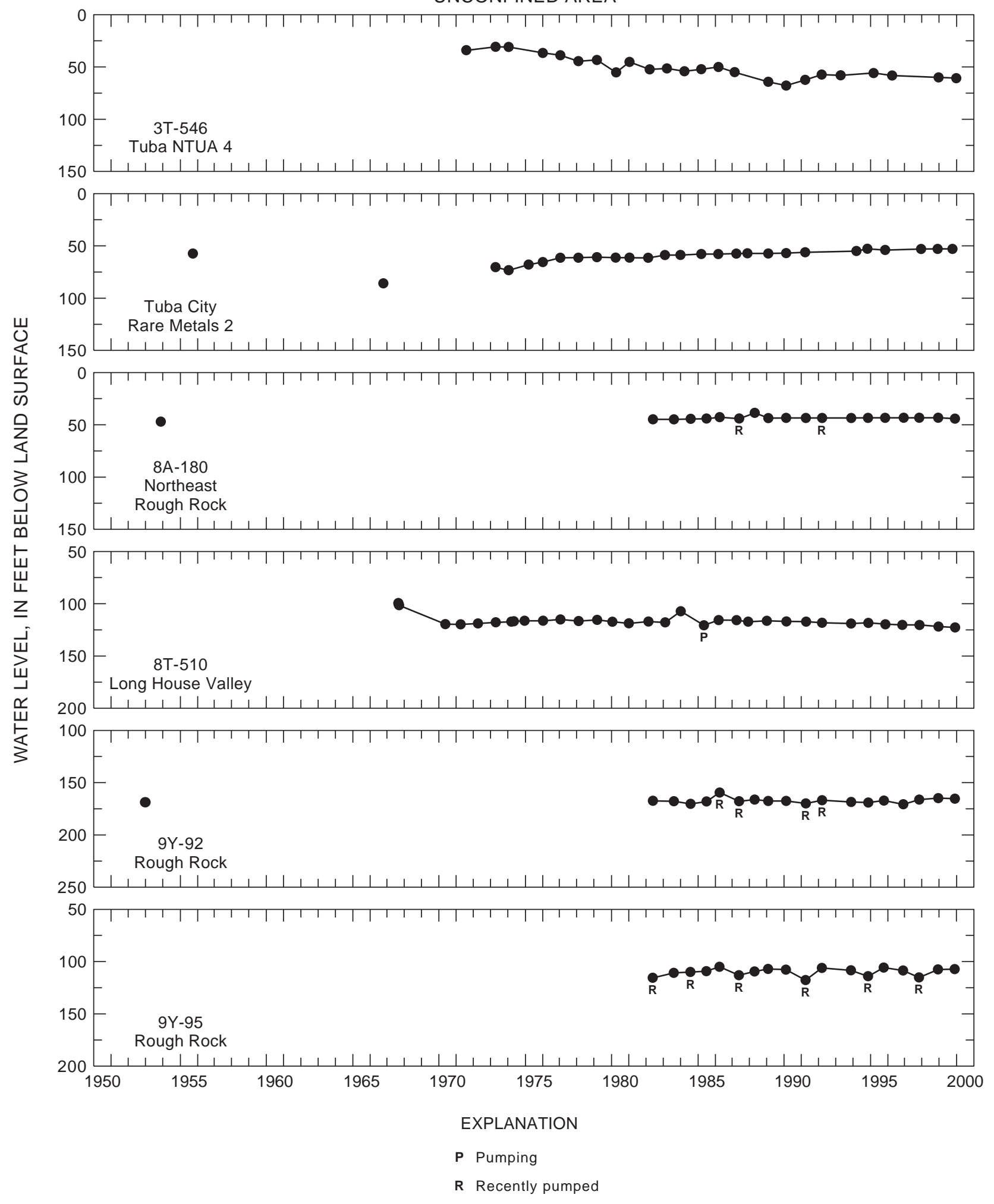

Figure 7. Continued. 


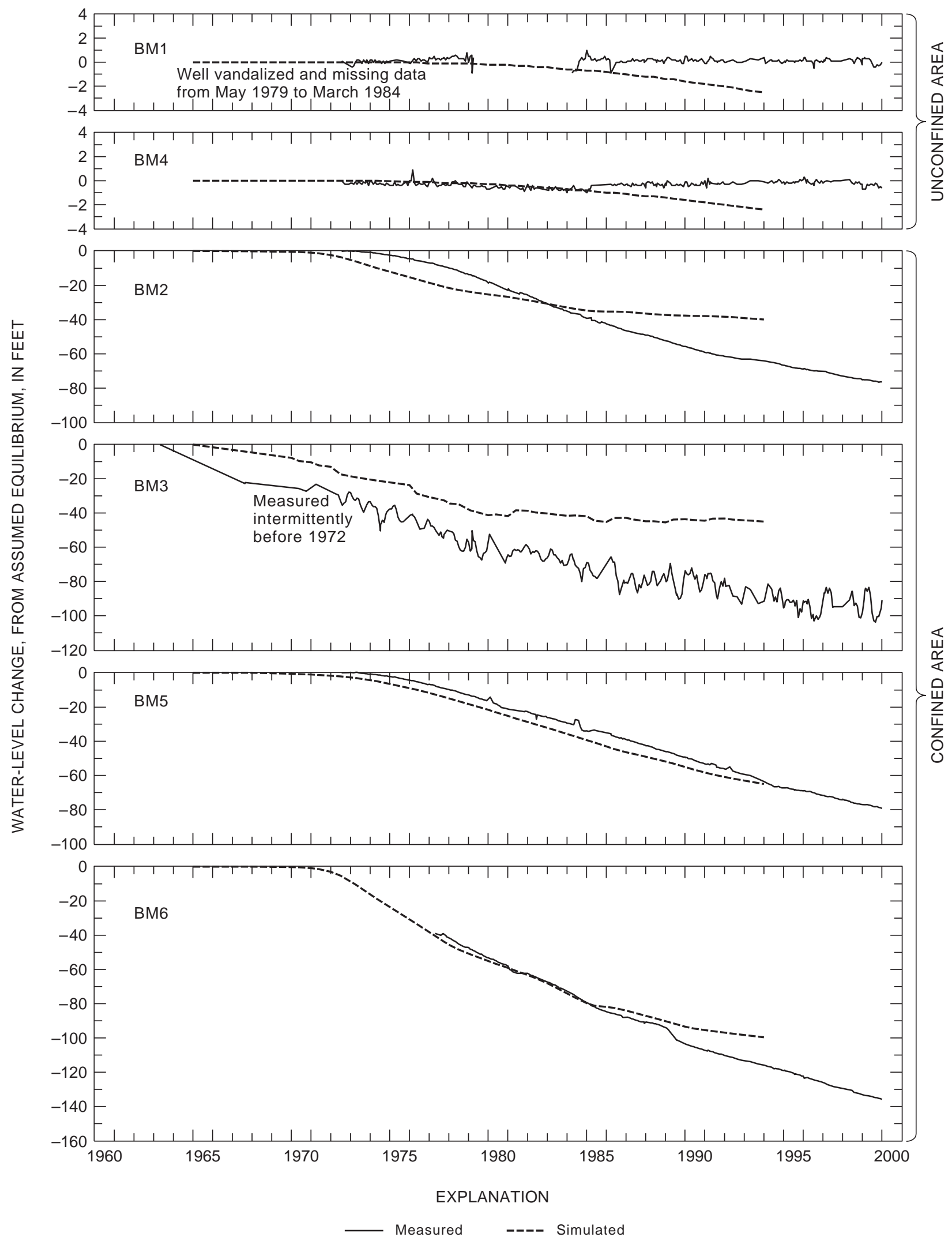

Figure 8. Measured water-level changes in continuous-record observation wells BM1-BM6, 1963-99, and simulated waterlevel changes, 1965-99, Black Mesa area, Arizona. Simulated data from Littin and Monroe (1995a). 
The 31 observation wells are classified as being in confined or unconfined areas of the $\mathrm{N}$ aquifer (table 5, fig. 5). After a review of data, this classification was changed for two wells since the last Black Mesa monitoring report (Truini and others, 2000). Wells 1K-214 (White Mesa Arch) and 8T-522 (Marsh Pass) were changed from unconfined to confined. This reclassification is not entirely certain, but most evidence points toward confined conditions. Water levels in these wells are above the top of the $\mathrm{N}$ aquifer and the aquifer is overlain by a confining bed, which is the definition of confined conditions. The open intervals, however, extend from the $\mathrm{N}$ aquifer to above the aquifer; therefore, there is uncertainty about the effect of water from overlying formations on the measured water levels. Because most of the open intervals are in the $\mathrm{N}$ aquifer, the assumption is that the measured water levels are largely controlled by water from the $\mathrm{N}$ aquifer.

\section{Spring Discharge from the N Aquifer}

Ground water in the $\mathrm{N}$ aquifer discharges from many springs around the margins of the Black Mesa area. Discharge from selected springs is measured annually and compared to discharge from previous years to determine changes in spring discharge over time. In December 1999, discharge was measured at four springs (table 7). Three springs are on the west or southwest side of the Black Mesa area, and one is on the northeast side (fig. 9). The discharge from these four springs represents only a small fraction of the total spring discharge from the $\mathrm{N}$ aquifer.

In 1999 , measured discharges were $0.3 \mathrm{gal} / \mathrm{min}$ from Burro Spring, $14.8 \mathrm{gal} / \mathrm{min}$ from an unnamed spring near Dennehotso, $13.3 \mathrm{gal} / \mathrm{min}$ from Moenkopi School Spring, and $38 \mathrm{gal} / \mathrm{min}$ from Pasture Canyon Spring. Compared to spring discharges in 1998, discharges did not change for Burro Spring, decreased by 30 percent for an unnamed spring near Dennehotso, increased by 11 percent for Moenkopi School Spring, and decreased by 3 percent for Pasture Canyon Spring. The discharges measured at all four springs represent only part of the total discharges from the springs.

Because of separate seeps and problematic measuring conditions, it would be difficult to measure the total discharge at those sites.
Long-term changes in spring discharge can be evaluated for the entire record at Burro Spring but can be evaluated only for parts of the records for the other three springs because discharge measuring points changed during the periods of record. Consistent measuring points are available for 1992-99 at an unnamed spring near Dennehotso, for 1987-99 at Moenkopi School Spring, and for 1995-99 at Pasture Canyon Spring. For the consistent periods of record at all four springs, the discharges have fluctuated; however, increasing or decreasing trends are not apparent.

\section{Surface-Water Discharge}

Surface-water discharge in the study area includes ground-water discharge and direct or shallow subsurface runoff of rainfall or snowmelt. Groundwater discharges to surface water at a fairly constant rate throughout the year. In contrast, the amount of rainfall or snowmelt runoff varies widely throughout the year. In the winter and spring, the amount and timing of snowmelt runoff is a result of the temporal variation in snow accumulation, air temperatures, and rate of snowmelt. Although most rainfall runoff is in the summer, rainfall can cause surface-water discharge any time of the year. The amount and timing of rainfall runoff is a result of the intensity and duration of thunderstorms in the summer and cyclonic storms in the fall, winter, and spring.

Data on surface-water discharge have been collected continuously at selected streams each year of the monitoring program. The discharge data provide useful information about ground-water discharge and about runoff from rainfall and snowmelt. In this study, the total discharge in streams is roughly separated into ground-water discharge and runoff so that the temporal trends in ground-water discharge can be monitored.

In 1999, continuous-record discharge data were collected at four streamflow-gaging stations (tables 811). The gaging stations are in four of the largest drainages of the study area-Moenkopi Wash, Laguna Creek, Dinnebito Wash, and Polacca Wash (fig. 9, table 12).

The annual average discharges for the four gaging stations vary considerably during their periods of record; therefore, it is difficult to discern any trends (fig. 10). The discharges in Moenkopi Wash appear to have become more variable during the last 10 years. 
Table 7. Discharge measurements of selected springs, Black Mesa area, Arizona, 1952-99

\begin{tabular}{|c|c|c|c|c|c|c|c|}
\hline $\begin{array}{l}\text { U.S. Bureau of } \\
\text { Indian Affairs } \\
\text { site number }\end{array}$ & Rock formation(s) & $\begin{array}{c}\text { Date of } \\
\text { measureme } \\
\text { nt }\end{array}$ & $\begin{array}{c}\text { Discharge, } \\
\text { in gallons } \\
\text { per minute }\end{array}$ & $\begin{array}{l}\text { U.S. Bureau of } \\
\text { Indian Affairs } \\
\text { site number }\end{array}$ & Rock formation(s) & $\begin{array}{c}\text { Date of } \\
\text { measuremen } \\
t\end{array}$ & $\begin{array}{c}\text { Discharge, } \\
\text { in gallons } \\
\text { per minute }\end{array}$ \\
\hline \multicolumn{4}{|c|}{ Burro Spring } & \multicolumn{4}{|c|}{ Moenkopi School Spring } \\
\hline \multirow[t]{8}{*}{$6 \mathrm{M}-31$} & \multirow[t]{8}{*}{ Navajo Sandstone } & $12-15-89$ & 0.4 & \multirow[t]{11}{*}{$3 G S-77-6$} & \multirow[t]{11}{*}{ Navajo Sandstone $^{1}$} & $05-16-52$ & 40 \\
\hline & & $12-13-90$ & 0.4 & & & $04-22-87$ & 216 \\
\hline & & 03-18-93 & 0.3 & & & $11-29-88$ & 212.5 \\
\hline & & $12-08-94$ & 0.2 & & & $02-21-91$ & 213.5 \\
\hline & & $12-17-96$ & 0.4 & & & 04-07-93 & 214.6 \\
\hline & & 12-30-97 & 0.2 & & & $12-07-94$ & ${ }^{2} 12.9$ \\
\hline & & $12-08-98$ & 0.3 & & & $12-04-95$ & ${ }^{2} 12.1$ \\
\hline & & $12-07-99$ & 0.3 & & & $12-16-96$ & 210 \\
\hline & \multicolumn{3}{|c|}{ Unnamed spring near Dennehotso } & & & $12-17-97$ & ${ }^{2} 13.1$ \\
\hline \multirow[t]{11}{*}{$8 A-224$} & Navajo Sandstone & $10-06-54$ & 31 & & & $12-08-98$ & ${ }^{2} 12.0$ \\
\hline & & $06-27-84$ & 32 & & & $12-13-99$ & ${ }^{2} 13.3$ \\
\hline & & $11-17-87$ & 35 & \multicolumn{4}{|c|}{ Pasture Canyon Spring } \\
\hline & & 03-26-92 & 16 & \multirow[t]{8}{*}{$3 A-5$} & \multirow[t]{8}{*}{$\begin{array}{l}\text { Navajo Sandstone, } \\
\text { alluvium }\end{array}$} & $11-18-88$ & 4211 \\
\hline & & $10-22-93$ & 14.4 & & & 03-24-92 & ${ }^{4} 233$ \\
\hline & & $12-05-95$ & 17 & & & $10-12-93$ & ${ }^{4} 211$ \\
\hline & & $12-19-96$ & 15.7 & & & $12-04-95$ & 538 \\
\hline & & $12-31-97$ & 25.6 & & & $12-16-96$ & $5_{38}$ \\
\hline & & $12-14-98$ & 21.0 & & & $12-17-97$ & $5_{40}$ \\
\hline & & $12-15-99$ & 14.8 & & & $12-10-98$ & $5_{39}$ \\
\hline & & & & & & $12-21-99$ & $5_{38}$ \\
\hline
\end{tabular}

\footnotetext{
${ }^{1}$ Tongue in the Kayenta Formation.

${ }^{2}$ Discharge measured at water-quality sampling site and at different point than the measurement in 1952 . Discharge does not represent total discharge from the Moenkopi School Spring system.

${ }^{3}$ Discharge measured at different point than later measurements and does not represent total discharge from unnamed spring near Dennehotso.

${ }^{4}$ Discharge measured in an irrigation ditch about 0.25 mile below water-quality sampling point and does not represent total discharge from Pasture Canyon Spring

${ }^{5}$ Discharge measured at water-quality sampling point 20 feet below uppermost spring. Discharge does not represent total discharge from Pasture Canyon Spring.
}

The ground-water discharge component of total flow at the four streamflow-gaging stations was roughly estimated by computing the median flow for four winter months-November, December, January, and February. Most flow during the winter is groundwater discharge because rainfall and snowmelt runoff are minimal. Most of the precipitation in the winter falls as snow, and the cold temperatures prevent appreciable snowmelt. Also, evapotranspiration from streams is at a minimum during the winter. During the summer, much of the flow in streams evaporates or is transpired by plants. The median flow for November, December, January, and February, rather than the average flow, is used to estimate ground-water discharge because the median is less affected by occasional winter runoff. The 120 consecutive daily mean flows for those four months were used to compute the median flow. These winter flows are a part of a water year-October 1 to September 30 .

The median flow for November, December, January, and February is an index of ground-water discharge rather than an absolute estimate of discharge. A more rigorous and accurate estimate would include detailed evaluations of streamflow hydrographs, flows into and out of bank storage, gain and loss of streamflow as it moves down the stream channel, and interaction of ground water in the $\mathrm{N}$ aquifer with ground water in the shallow alluvial aquifers in the stream valleys. The median winter flow, however, is useful as a consistent index for evaluating time trends in ground-water discharge. 


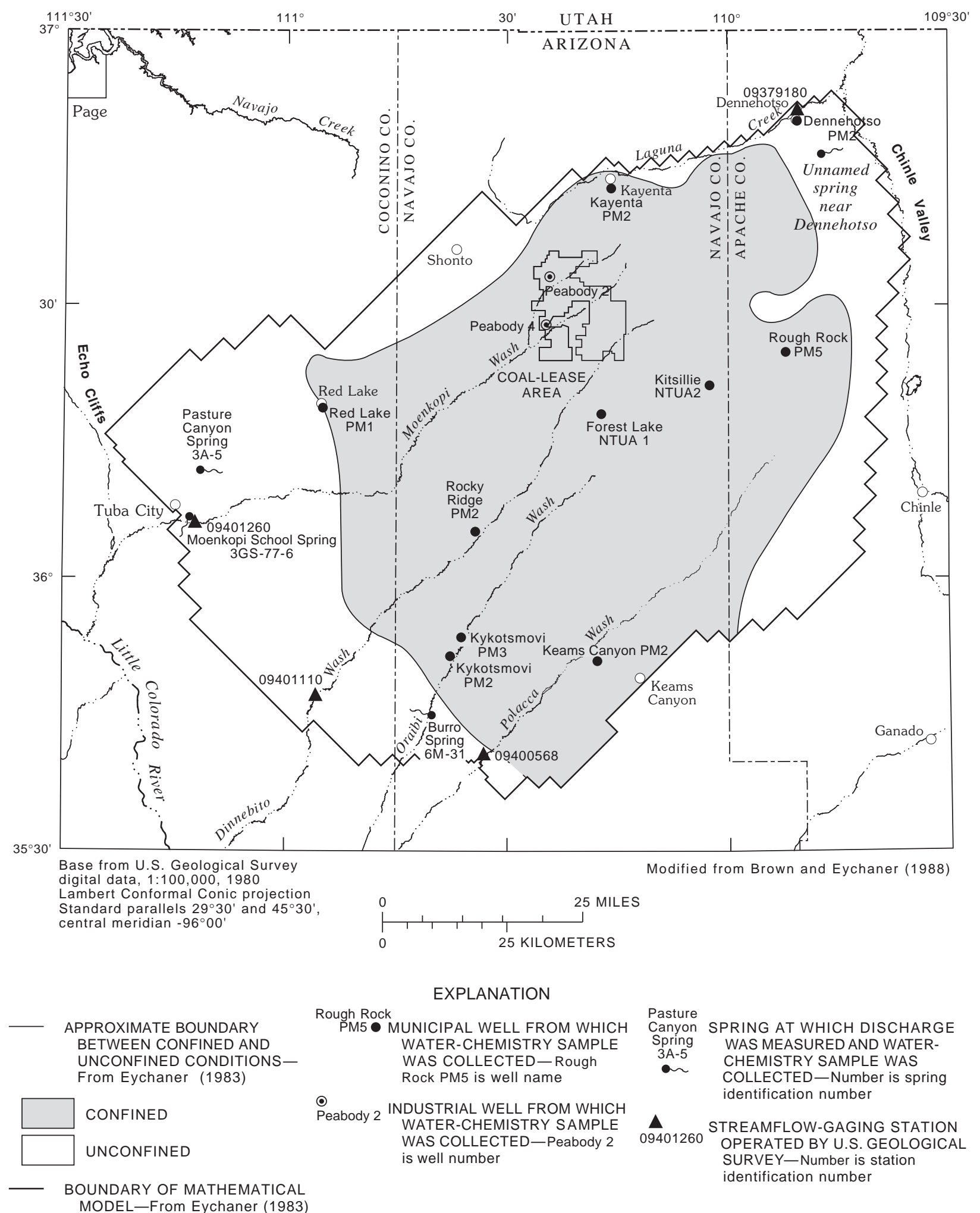

Figure 9. Surface-water and water-chemistry data-collection sites, Black Mesa area, Arizona, 1999. 
Table 8. Discharge data, Moenkopi Wash at Moenkopi, Arizona (09401260), calendar year 1999

[Dashes indicate no data]

DISCHARGE, IN CUBIC FEET PER SECOND, CALENDAR YEAR 1999 DAILY MEAN VALUES

\begin{tabular}{|c|c|c|c|c|c|c|c|c|c|c|c|c|}
\hline Day & Jan. & Feb. & Mar. & Apr. & May & June & July & Aug. & Sept. & Oct. ${ }^{1}$ & Nov. $^{1}$ & Dec. ${ }^{1}$ \\
\hline 1 & 4.2 & 23.7 & 2.5 & 3.2 & 3.1 & ${ }^{2} 0.30$ & 0.0 & 13 & 1,200 & 1.2 & 1.7 & 1.7 \\
\hline 2 & 2.6 & ${ }^{2} 2.7$ & 2.6 & 3.3 & 3.0 & 22.0 & .0 & 230 & 156 & 1.1 & 1.8 & 2.1 \\
\hline 3 & 2.1 & 22.7 & 2.6 & 3.6 & 3.3 & 14 & .0 & 6.8 & 44 & 1.1 & 1.8 & 2.6 \\
\hline 4 & 1.7 & ${ }^{2} 2.7$ & 2.4 & 3.4 & 14 & 2.7 & .0 & 69 & 17 & 1.1 & 2.0 & 3.0 \\
\hline 5 & 2.7 & 3.5 & 2.4 & 3.6 & 7.6 & .83 & .0 & 29 & 9.5 & 1.1 & 2.0 & 2.3 \\
\hline 6 & 2.9 & 3.2 & 2.3 & 3.5 & 1.5 & .97 & .0 & ${ }^{2} 10$ & 5.3 & ${ }^{2} .99$ & 2.0 & 1.3 \\
\hline 7 & 3.5 & 3.1 & 2.4 & 3.0 & 1.6 & .63 & .22 & ${ }^{2} 10$ & 3.1 & .83 & 2.0 & 4.2 \\
\hline 8 & 3.3 & 3.2 & 2.5 & 2.4 & 1.1 & .14 & 4.1 & 25.0 & 2.2 & .83 & 2.2 & 3.5 \\
\hline 9 & 3.0 & 3.1 & 2.4 & 3.2 & ${ }^{2} .50$ & .01 & 4.4 & 24.0 & 1.5 & .82 & 2.2 & 3.3 \\
\hline 10 & 3.2 & 3.3 & 2.3 & 3.1 & .23 & .0 & 5.0 & 23.0 & .94 & 1.0 & 2.1 & 5.5 \\
\hline 11 & 3.2 & 2.9 & 2.4 & 3.2 & .23 & .03 & 4.9 & 23.0 & 22 & 1.1 & 1.8 & 8.9 \\
\hline 12 & 4.0 & 2.4 & 2.5 & 2.9 & .17 & .03 & 4.8 & 23.0 & 88 & 1.1 & 1.8 & 3.5 \\
\hline 13 & 23.7 & 2.8 & 2.3 & 3.9 & .22 & .0 & 24.0 & 23.0 & 14 & .95 & 1.8 & 7.1 \\
\hline 14 & ${ }^{2} 2.7$ & ${ }^{2} 2.7$ & 2.2 & 3.4 & .09 & .0 & 24.0 & 23.0 & 8.2 & .83 & 1.8 & 5.4 \\
\hline 15 & ${ }^{2} 2.7$ & 3.0 & 2.4 & 3.1 & .37 & .0 & 2.90 & 23.0 & 6.7 & .82 & 1.8 & 3.8 \\
\hline 16 & 23.7 & ${ }^{2} 2.2$ & 2.6 & 2.8 & 1.3 & .0 & 3.8 & 27.0 & 8.7 & .76 & 1.9 & 4.8 \\
\hline 17 & 23.7 & 2.5 & 3.2 & 3.1 & 1.8 & .0 & ${ }^{2} 1.0$ & 27.0 & 38 & .66 & 1.9 & 3.9 \\
\hline 18 & 3.3 & 2.5 & 3.2 & 3.3 & 1.8 & .0 & ${ }^{2} .50$ & 24.4 & 9.7 & .86 & 1.8 & 4.1 \\
\hline 19 & 3.1 & ${ }^{2} 2.2$ & 3.0 & 3.0 & 2.0 & .0 & ${ }^{2} .50$ & 120 & 24.0 & 1.1 & 1.8 & 4.4 \\
\hline 20 & 3.2 & 2.6 & 2.8 & 2.6 & 24.0 & .0 & .55 & 860 & ${ }^{2} 2.0$ & 1.2 & 1.8 & 5.0 \\
\hline 21 & 3.2 & 2.4 & 2.7 & 3.3 & 8.8 & .0 & .19 & 65 & ${ }^{2} 1.5$ & 1.1 & ${ }^{2} .2$ & 5.0 \\
\hline 22 & 23.0 & 2.3 & 2.7 & 3.5 & 5.2 & .0 & 2.20 & 23 & 1.4 & 1.4 & 2.1 & 5.4 \\
\hline 23 & 23.0 & 2.7 & 2.8 & 4.2 & .77 & .0 & ${ }^{2} 2.0$ & ${ }^{2} 10$ & 10 & 1.4 & 2.2 & 5.5 \\
\hline 24 & 3.3 & 2.5 & 2.8 & 3.9 & .82 & .0 & 21 & ${ }^{2} 10$ & 29 & 1.6 & 3.0 & 5.2 \\
\hline 25 & 2.8 & 2.5 & 2.9 & 3.4 & .64 & .0 & 11 & ${ }^{2} 10$ & 7.1 & 1.5 & 4.4 & 5.5 \\
\hline 26 & 3.1 & 2.5 & 2.9 & 3.2 & .66 & .0 & 1.2 & 21 & ${ }^{2} 1.8$ & 1.5 & 3.6 & 7.2 \\
\hline 27 & 23.2 & 2.6 & 2.9 & 3.0 & 1.6 & .0 & ${ }^{2} .70$ & 56 & ${ }^{2} 1.0$ & 1.5 & 4.3 & 6.0 \\
\hline 28 & 23.7 & 2.7 & 2.8 & 2.8 & 2.4 & .0 & 674 & 1,050 & .80 & 1.1 & 2.2 & 6.7 \\
\hline 29 & 3.3 & --- & 2.7 & 2.9 & ${ }^{2} 2.0$ & .0 & 100 & 917 & .81 & 1.2 & 2.3 & 7.3 \\
\hline 30 & 4.2 & --- & 2.8 & 3.4 & ${ }^{2} .60$ & .0 & 14 & 301 & 1.1 & 1.4 & 2.9 & 6.5 \\
\hline 31 & 3.9 & --- & 2.8 & --- & ${ }^{2} .40$ & --- & 2.2 & 48 & --- & 1.5 & --- & 8.6 \\
\hline TOTAL & 99.2 & 77.2 & 81.8 & 97.2 & 71.80 & 21.64 & 954.26 & $3,704.2$ & $1,695.35$ & 34.65 & 67.2 & 149.3 \\
\hline MEAN & 3.2 & 2.8 & 2.6 & 3.2 & 2.3 & .72 & 31 & 120 & 56 & 1.1 & 2.2 & 4.8 \\
\hline MAX & 4.2 & 3.7 & 3.2 & 4.2 & 14 & 14 & 674 & 1,050 & 1,200 & 1.6 & 4.4 & 8.9 \\
\hline MIN & 1.7 & 2.2 & 2.2 & 2.4 & .09 & .0 & .0 & 3.0 & .80 & .66 & 1.7 & 1.3 \\
\hline AC-FT & 197 & 153 & 162 & 193 & 142 & 43 & 1,890 & 7,350 & 3,360 & 69 & 133 & 296 \\
\hline \multicolumn{3}{|c|}{ CALENDAR YEAR 1999} & \multicolumn{2}{|c|}{ TOTAL 7,053.8 } & \multicolumn{2}{|l|}{ MEAN 19.3} & \multicolumn{2}{|c|}{ MAXIMUM 1,200 } & \multicolumn{2}{|c|}{ MINIMUM 0.0} & \multicolumn{2}{|c|}{ ACRE-FT 13,991 } \\
\hline
\end{tabular}


Table 9. Discharge data, Laguna Creek at Dennehotso, Arizona (09379180), calendar year 1999 [Dashes indicate no data]

\section{DISCHARGE, IN CUBIC FEET PER SECOND, CALENDAR YEAR 1999} DAILY MEAN VALUES

\begin{tabular}{|c|c|c|c|c|c|c|c|c|c|c|c|c|}
\hline Day & Jan. & Feb. & Mar. & Apr. & May & June & July & Aug. & Sept. & Oct. ${ }^{1}$ & Nov. $^{1}$ & Dec. $^{1}$ \\
\hline 1 & ${ }^{2} 1.7$ & ${ }^{2} 0.40$ & 1.4 & 2.8 & 0.18 & 0.0 & 0.0 & 6.4 & 7.1 & 0.24 & 1.7 & 2.3 \\
\hline 2 & 22.9 & 2.70 & .95 & .79 & .14 & .0 & .0 & 4.6 & 10 & .03 & 1.8 & 2.1 \\
\hline 3 & 25.5 & 23.8 & .82 & 3.7 & .17 & .0 & .0 & 17 & 4.3 & .55 & 1.8 & 2.0 \\
\hline 4 & 24.4 & 23.2 & .67 & 11 & .20 & .0 & .0 & 54 & 2.3 & .27 & 1.8 & 1.1 \\
\hline 5 & 23.4 & 23.8 & .48 & 25 & .15 & .0 & .0 & 62 & .95 & .09 & 1.9 & .66 \\
\hline 6 & 23.2 & 23.8 & .45 & 13 & 1.7 & .0 & .0 & 11 & .48 & .0 & 1.9 & .22 \\
\hline 7 & 23.7 & 22.9 & .40 & 5.8 & .16 & .0 & .0 & 5.8 & .19 & 1.1 & ${ }^{2} 1.7$ & .49 \\
\hline 8 & ${ }^{2} 1.9$ & 6.2 & .38 & 2.4 & .13 & .0 & .08 & 2.2 & .07 & .45 & ${ }^{2} 1.7$ & .54 \\
\hline 9 & ${ }^{2} 1.6$ & 4.5 & .38 & 1.6 & .04 & .0 & 14 & 3.5 & .30 & .58 & ${ }^{2} 1.5$ & .11 \\
\hline 10 & 23.5 & 5.0 & 2.2 & .65 & .0 & .0 & 87 & 1.8 & .04 & .50 & ${ }^{2} 1.7$ & .93 \\
\hline 11 & 23.8 & 2.8 & 1.5 & .46 & .0 & .0 & 9.1 & 5.9 & 66 & .41 & ${ }^{2} 1.7$ & .58 \\
\hline 12 & 23.6 & ${ }^{2} .80$ & .52 & .47 & .0 & .0 & 2.3 & 2.7 & 53 & .75 & ${ }^{2} 1.8$ & 2.6 \\
\hline 13 & ${ }^{2} 2.5$ & ${ }^{2} .60$ & .57 & .50 & .0 & .0 & .81 & 1.6 & 11 & .84 & ${ }^{2} 1.8$ & 2.6 \\
\hline 14 & 22.9 & ${ }^{2} .50$ & 1.0 & .53 & .0 & .0 & .39 & .93 & 10 & .27 & ${ }^{2} 1.9$ & 3.6 \\
\hline 15 & 23.6 & ${ }^{2} 1.4$ & 1.5 & .80 & .0 & .0 & 38 & 1.0 & 4.1 & .07 & ${ }^{2} 1.9$ & .45 \\
\hline 16 & 7.7 & 23.8 & 1.6 & .50 & .0 & .0 & 28 & 47 & 7.3 & 1.3 & 22.0 & .88 \\
\hline 17 & 6.6 & 24.4 & 1.1 & .48 & .0 & .0 & 4.5 & 7.3 & 9.4 & 1.3 & 22.0 & .65 \\
\hline 18 & ${ }^{2} 2.5$ & 22.8 & .89 & .51 & .0 & 19 & 1.6 & 11 & 10 & .65 & 1.6 & 2.0 \\
\hline 19 & 24.9 & ${ }^{2} 2.2$ & .51 & .58 & .0 & 13 & .73 & 115 & 5.2 & .71 & 1.4 & .70 \\
\hline 20 & 28.5 & 22.4 & 1.5 & .35 & .0 & 1.5 & .06 & 122 & 2.2 & 1.2 & 1.6 & 1.4 \\
\hline 21 & 7.9 & 2.1 & 1.1 & .18 & .0 & .03 & .06 & 22 & 1.1 & .90 & 2.1 & 2.0 \\
\hline 22 & 4.8 & 1.7 & .51 & .26 & .0 & .0 & 1.9 & 6.8 & .09 & .58 & 2.1 & 3.9 \\
\hline 23 & 22.3 & 2.0 & .34 & 1.1 & .0 & .0 & 1.5 & 3.0 & .0 & .36 & 1.6 & 2.4 \\
\hline 24 & ${ }^{2} 2.5$ & .95 & .25 & 13 & .0 & .0 & .03 & 2.0 & 4.0 & 1.8 & .51 & 2.0 \\
\hline 25 & 23.3 & 1.1 & .23 & 7.3 & .0 & .0 & .0 & 29 & 8.3 & 1.6 & .47 & .83 \\
\hline 26 & 6.7 & 4.0 & 1.0 & 1.6 & .0 & .0 & .0 & 25 & 3.4 & 1.3 & .82 & .29 \\
\hline 27 & 4.4 & 5.2 & .52 & .62 & .0 & .0 & .0 & 14 & 1.7 & 1.2 & .97 & .75 \\
\hline 28 & 3.4 & 3.2 & .55 & .31 & .0 & .0 & 563 & 22 & .70 & 1.4 & 4.4 & 6.6 \\
\hline 29 & ${ }^{2} 1.6$ & --- & .55 & .27 & .0 & .0 & 134 & 10 & .32 & 1.6 & 3.3 & 3.2 \\
\hline 30 & ${ }^{2} 0.50$ & --- & .54 & .15 & .0 & .0 & 23 & 3.2 & .33 & 1.5 & 2.2 & 4.0 \\
\hline 31 & 2.40 & --- & 1.8 & --- & .0 & --- & 13 & 4.7 & --- & 1.5 & --- & 1.2 \\
\hline TOTAL & 116.20 & 76.25 & 26.21 & 96.71 & 2.87 & 33.53 & 923.06 & 624.43 & 223.87 & 23.05 & 53.67 & 53.08 \\
\hline MEAN & 3.8 & 2.7 & .85 & 3.2 & .09 & 1.1 & 30 & 20 & 7.5 & .81 & 1.8 & 1.7 \\
\hline MAX & 8.5 & 6.2 & 2.2 & 25 & 1.7 & 19 & 563 & 122 & 66 & 1.8 & 4.4 & 6.6 \\
\hline MIN & .40 & .40 & .23 & .15 & .0 & .0 & .0 & .93 & .0 & .0 & .47 & .11 \\
\hline AC-FT & 230 & 151 & 52 & 192 & 5.7 & 67 & 1,830 & 1,240 & 444 & 50 & 106 & 105 \\
\hline \multicolumn{3}{|c|}{ CALENDAR YEAR 1999} & \multicolumn{2}{|c|}{ TOTAL 2,252.93 } & MEAN & 6.2 & \multicolumn{2}{|c|}{ MAXIMUM 563} & MINIMUM & 0.0 & \multicolumn{2}{|c|}{ ACRE-FT 4,469} \\
\hline
\end{tabular}


Table 10. Discharge data, Dinnebito Wash near Sand Springs, Arizona (09401110), calendar year 1999

[Dashes indicate no data]

\section{DISCHARGE, IN CUBIC FEET PER SECOND, CALENDAR YEAR 1999} DAILY MEAN VALUES

\begin{tabular}{|c|c|c|c|c|c|c|c|c|c|c|c|c|}
\hline Day & Jan. & Feb. & Mar. & Apr. & May & June & July & Aug. & Sept. & Oct. ${ }^{1}$ & Nov. ${ }^{1}$ & Dec. ${ }^{1}$ \\
\hline 1 & 0.48 & 0.46 & 0.42 & 0.54 & 0.48 & 0.25 & ${ }^{2} 0.20$ & ${ }^{2} 10$ & 2340 & 0.37 & 0.38 & 0.31 \\
\hline 2 & .41 & .44 & .42 & .73 & .44 & .30 & 2.20 & ${ }^{2} 1.1$ & 245 & .35 & .38 & .30 \\
\hline 3 & .42 & .48 & .40 & .50 & .43 & .30 & ${ }^{2} .20$ & 27.3 & ${ }^{2} 1.2$ & .34 & .39 & .28 \\
\hline 4 & .38 & .48 & .37 & .52 & .74 & .22 & ${ }^{22} .20$ & ${ }^{2} 20$ & 2.40 & .34 & .41 & .30 \\
\hline 5 & .42 & .49 & .38 & .49 & .47 & .30 & 2.20 & ${ }^{2} 0.48$ & 2.39 & .34 & .40 & .29 \\
\hline 6 & .45 & .47 & .41 & .42 & .47 & .29 & 2.20 & ${ }^{2} .13$ & 2.39 & .29 & .40 & .31 \\
\hline 7 & .45 & .46 & .38 & .39 & .48 & .23 & .36 & $2 \cdot 13$ & ${ }^{2} .34$ & .29 & .40 & .33 \\
\hline 8 & .43 & .46 & .39 & .42 & .44 & .20 & 25.8 & 2.13 & .33 & .34 & .40 & .34 \\
\hline 9 & .41 & .43 & .41 & .38 & .39 & .21 & ${ }^{2} 15$ & ${ }^{2} .13$ & .32 & .33 & .30 & .30 \\
\hline 10 & .43 & .50 & .42 & .44 & .41 & .20 & ${ }^{2} 130$ & 2.13 & .32 & .34 & .28 & .33 \\
\hline 11 & .46 & .39 & .41 & .45 & .43 & .21 & 25.4 & ${ }^{2} .13$ & 102 & .34 & .28 & .30 \\
\hline 12 & .26 & .44 & .40 & .41 & .44 & .22 & 24.4 & ${ }^{2} .13$ & 23 & .34 & .28 & .28 \\
\hline 13 & .44 & .47 & .41 & .43 & .37 & .21 & ${ }^{2} 1.2$ & ${ }^{2} .13$ & 2.5 & .34 & .28 & .31 \\
\hline 14 & .45 & .47 & .44 & .40 & .33 & .20 & 22.6 & ${ }^{2} .13$ & 2.0 & .35 & .29 & .31 \\
\hline 15 & .41 & .48 & .41 & .40 & .34 & .19 & 279 & ${ }^{2} .13$ & .83 & .33 & .26 & .19 \\
\hline 16 & .48 & .44 & .42 & .43 & .37 & .19 & ${ }^{2} 14$ & ${ }^{2} .13$ & .36 & .31 & .26 & .22 \\
\hline 17 & .47 & .47 & .46 & .47 & .40 & .22 & 2.7 & 25.6 & 78 & .32 & .28 & .41 \\
\hline 18 & .49 & .46 & .44 & .47 & .42 & 223 & .64 & 230 & 5.6 & .35 & .28 & .35 \\
\hline 19 & .49 & .45 & .43 & .47 & .39 & ${ }^{2} .20$ & .31 & 279 & 1.5 & .36 & .31 & .33 \\
\hline 20 & .48 & .44 & .41 & .45 & .37 & 2.20 & .25 & 242 & .80 & .36 & .30 & .30 \\
\hline 21 & .49 & .42 & .42 & .43 & .38 & ${ }^{2} .20$ & .24 & ${ }^{2} 12$ & .44 & .37 & .30 & .30 \\
\hline 22 & .43 & .39 & .44 & .45 & .33 & ${ }^{2} .20$ & .59 & ${ }^{2} 1.7$ & .38 & .38 & .29 & .29 \\
\hline 23 & .46 & .42 & .43 & .57 & .30 & 2.20 & ${ }^{2} 15$ & 2.76 & .76 & .38 & 1.6 & .29 \\
\hline 24 & .50 & .46 & .45 & .44 & .32 & ${ }^{2} .20$ & ${ }^{2} 6.7$ & ${ }^{2} 1.5$ & 1.0 & .37 & .34 & .30 \\
\hline 25 & .45 & .42 & .46 & .56 & .39 & ${ }^{2} .20$ & ${ }^{2} 1.3$ & ${ }^{2} .56$ & 2.8 & .38 & .31 & .33 \\
\hline 26 & .46 & .42 & .42 & .47 & .40 & 2.20 & ${ }^{2} 1.2$ & ${ }^{2} 61$ & 1.0 & .37 & .33 & .35 \\
\hline 27 & .46 & .44 & .38 & .44 & .36 & ${ }^{2} .20$ & ${ }^{2} .31$ & ${ }^{2} 24$ & .38 & .36 & .36 & .32 \\
\hline 28 & .43 & .45 & .37 & .41 & .32 & 2.20 & 224 & ${ }^{2} 160$ & .33 & .36 & .35 & .32 \\
\hline 29 & .41 & --- & .39 & .43 & .27 & ${ }^{2} .20$ & ${ }^{2} 56$ & ${ }^{2} 160$ & .36 & .34 & .34 & .32 \\
\hline 30 & .41 & --- & .40 & .47 & .25 & 2.20 & 241 & ${ }^{2} 120$ & .38 & .35 & .33 & .32 \\
\hline 31 & .46 & --- & .34 & --- & .25 & --- & ${ }^{2} 19$ & ${ }^{2} 67$ & --- & .38 & --- & .33 \\
\hline TOTAL & 13.67 & 12.60 & 12.73 & 13.88 & 12.18 & 29.34 & 428.20 & 805.43 & 613.11 & 10.77 & 11.11 & 9.56 \\
\hline MEAN & .44 & .45 & .41 & .46 & .39 & .98 & 14 & 26 & 20 & .35 & .37 & .31 \\
\hline MAX & .50 & .50 & .46 & .73 & .74 & 23 & 130 & 160 & 340 & .38 & 1.6 & .41 \\
\hline MIN & .26 & .39 & .34 & .38 & .25 & .19 & .20 & .13 & .32 & .29 & .26 & .19 \\
\hline AC-FT & 27 & 25 & 25 & 28 & 24 & 58 & 849 & 1,600 & 1,220 & 21 & 22 & 19 \\
\hline \multicolumn{3}{|c|}{ CALENDAR YEAR 1999} & \multicolumn{2}{|c|}{ TOTAL $1,972.58$} & \multicolumn{2}{|l|}{ MEAN 5.4} & \multicolumn{2}{|c|}{ MAXIMUM 340} & \multicolumn{2}{|c|}{ MINIMUM 0.13} & \multicolumn{2}{|c|}{ ACRE-FT 3,913 } \\
\hline
\end{tabular}

${ }^{1}$ Month in which data are provisional, subject to revision.

${ }^{2}$ Estimated. 
Table 11. Discharge data, Polacca Wash near Second Mesa, Arizona (09400568), calendar year 1999

[Dashes indicate no data]

\section{DISCHARGE, IN CUBIC FEET PER SECOND, CALENDAR YEAR 1999} DAILY MEAN VALUES

\begin{tabular}{|c|c|c|c|c|c|c|c|c|c|c|c|c|}
\hline Day & Jan. & Feb. & Mar. & Apr. & May & June & July & Aug. & Sept. & Oct. ${ }^{1}$ & Nov. ${ }^{1}$ & Dec. ${ }^{1}$ \\
\hline 1 & 0.21 & 0.25 & 0.26 & 0.82 & 0.23 & 0.09 & 0.07 & 0.49 & 26 & 0.11 & 0.14 & 0.15 \\
\hline 2 & .20 & .25 & .26 & .95 & .22 & .10 & .08 & 8.2 & 4.5 & .11 & .75 & .14 \\
\hline 3 & .20 & .26 & .25 & .45 & .22 & .11 & .17 & 8.1 & 0.44 & .11 & .19 & .15 \\
\hline 4 & .21 & .25 & .23 & .37 & .28 & .09 & .09 & 4.4 & .06 & .11 & .16 & .14 \\
\hline 5 & .23 & .25 & .25 & .33 & .21 & .10 & .08 & 67 & .06 & .11 & .01 & .14 \\
\hline 6 & .25 & .23 & .25 & .26 & .21 & .10 & .08 & 32 & .06 & .10 & .0 & .15 \\
\hline 7 & .25 & .24 & .24 & .24 & .21 & .09 & .07 & 1.9 & .05 & .10 & .0 & .17 \\
\hline 8 & .23 & .24 & .24 & .25 & .20 & .08 & .05 & .14 & .05 & .11 & .0 & .15 \\
\hline 9 & .23 & .23 & .25 & .26 & .17 & .08 & .05 & .07 & .05 & .12 & .06 & .11 \\
\hline 10 & .25 & .24 & .24 & .29 & .16 & .08 & .21 & .06 & .05 & .12 & .13 & .15 \\
\hline 11 & .26 & .24 & .25 & .25 & .17 & .08 & .11 & .05 & 20 & .11 & .13 & .16 \\
\hline 12 & .22 & .32 & .24 & .22 & .17 & .08 & .06 & .04 & 1.5 & .12 & .13 & .12 \\
\hline 13 & .22 & .32 & .25 & .24 & .16 & .09 & .06 & .04 & 33 & .11 & .13 & .15 \\
\hline 14 & .23 & .31 & .25 & .22 & .14 & .08 & .90 & .04 & 22 & .11 & .13 & .11 \\
\hline 15 & .26 & .25 & .25 & .22 & .14 & .07 & 1.9 & .06 & 4.1 & .11 & .14 & .08 \\
\hline 16 & .24 & .25 & .26 & .22 & .14 & .07 & .12 & .05 & .26 & .10 & .14 & .09 \\
\hline 17 & .23 & .25 & .38 & .23 & .15 & .08 & .07 & .05 & 34 & .10 & .14 & .12 \\
\hline 18 & .23 & .25 & .29 & .23 & .15 & .14 & .07 & .06 & 4.6 & .12 & .13 & .12 \\
\hline 19 & .22 & .25 & .28 & .23 & .14 & .08 & .08 & 14 & 15 & .12 & .14 & .13 \\
\hline 20 & .22 & .25 & .25 & .23 & .14 & .07 & .07 & 130 & 4.8 & .13 & .14 & .12 \\
\hline 21 & .25 & .24 & .23 & .22 & .14 & .07 & .07 & 73 & .26 & .13 & .14 & .11 \\
\hline 22 & .22 & .23 & .23 & .22 & .13 & .06 & .07 & 12 & .12 & .13 & .13 & .11 \\
\hline 23 & .25 & .26 & .23 & .22 & .12 & .06 & .08 & 4.1 & 17 & .13 & .12 & .10 \\
\hline 24 & .23 & .26 & .24 & .22 & .12 & .06 & .08 & 1.5 & 88 & .14 & .12 & .12 \\
\hline 25 & .22 & .25 & .24 & .25 & .14 & .07 & .07 & .21 & 15 & .13 & .13 & .12 \\
\hline 26 & .23 & .25 & .25 & .23 & .15 & .06 & 13 & 4.4 & 1.5 & .13 & .16 & .14 \\
\hline 27 & .22 & .25 & .24 & .22 & .14 & .06 & 18 & 23 & .17 & .13 & .16 & .15 \\
\hline 28 & .23 & .25 & .23 & .21 & .13 & .07 & 4.4 & 139 & .10 & .13 & .15 & .14 \\
\hline 29 & .24 & -- & .23 & .20 & .11 & .07 & 1.4 & 143 & .11 & .12 & .15 & .15 \\
\hline 30 & .26 & --- & .23 & .21 & .10 & .07 & 11 & 214 & .11 & .12 & .15 & .13 \\
\hline 31 & .30 & --- & .22 & -- & .10 & --- & 1.2 & 87 & --- & .13 & --- & .14 \\
\hline TOTAL & 7.24 & 7.12 & 7.74 & 8.71 & 4.99 & 2.41 & 53.76 & 967.95 & 292.95 & 3.65 & 4.20 & 4.06 \\
\hline MEAN & .23 & .25 & .25 & .29 & .16 & .08 & 1.7 & 31 & 9.8 & .12 & .14 & .13 \\
\hline MAX & .30 & .32 & .38 & .95 & .28 & .14 & 18 & 214 & 88 & .14 & .75 & .17 \\
\hline MIN & .20 & .23 & .22 & .20 & .10 & .06 & .05 & .04 & .05 & .10 & .0 & .08 \\
\hline AC-FT & 14 & 14 & 15 & 17 & 9.9 & 4.8 & 107 & 1,920 & 581 & 7.2 & 8.3 & 8.1 \\
\hline \multicolumn{3}{|c|}{ CALENDAR YEAR 1999} & \multicolumn{2}{|c|}{ TOTAL $1,364.78$} & MEAN 3.7 & & \multicolumn{2}{|c|}{ MAXIMUM 214} & MINIMU & & \multicolumn{2}{|c|}{ ACRE-FT 2,707 } \\
\hline
\end{tabular}

Table 12. Date that data collection began and drainage areas for streamflow-gaging stations, Black Mesa area, Arizona

\begin{tabular}{lccc}
\hline \multicolumn{1}{c}{ Station name } & Station number & $\begin{array}{c}\text { Date data collection } \\
\text { began }\end{array}$ & $\begin{array}{c}\text { Drainage area, in square } \\
\text { miles }\end{array}$ \\
\hline Moenkopi Wash at Moenkopi & 09401260 & July 1976 & 1,629 \\
Laguna Creek at Dennehotso & 09379180 & July 1996 & 414 \\
Dinnebito Wash near Sand Springs & 09401110 & June 1993 & 473 \\
Polacca Wash near Second Mesa & 09400568 & April 1994 & 905 \\
\hline
\end{tabular}


A. Annual average discharge for calender years 1977-99

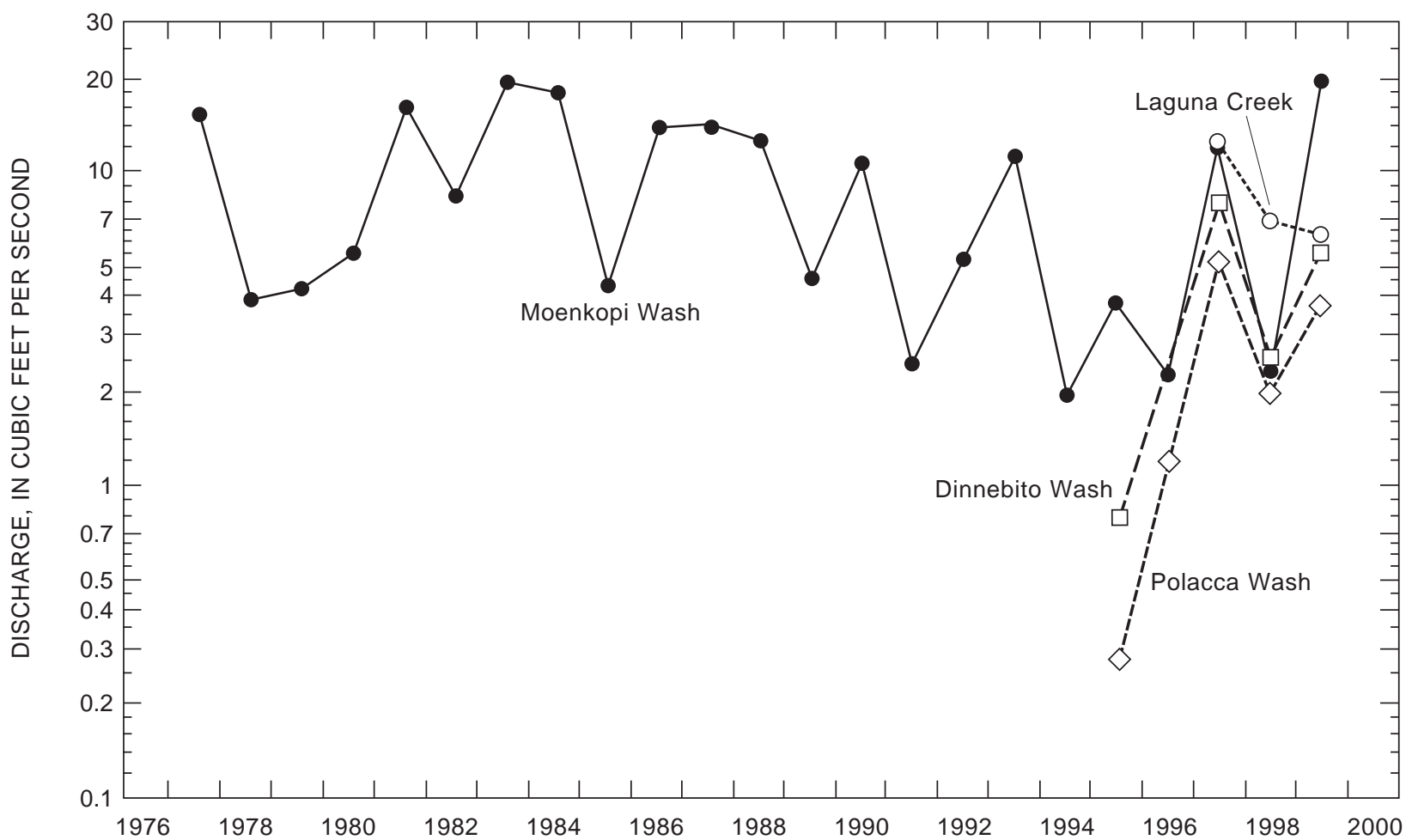

B. Median discharge for November, December, January, and February for water years 1977-99

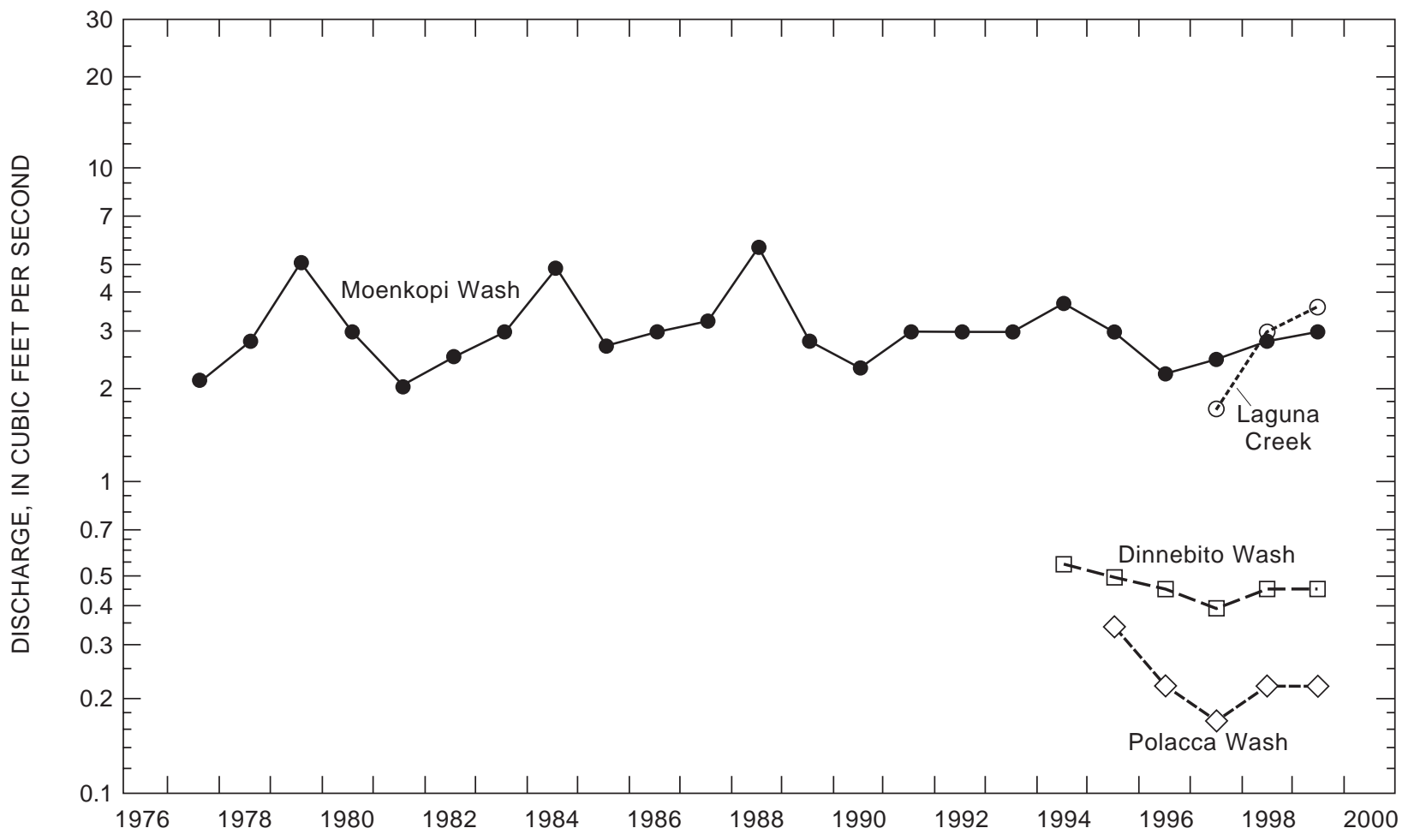

Figure 10. Annual average discharge and median winter discharge, Moenkopi Wash (09401260), Laguna Creek (09379180), Dinnebito Wash (09401110), and Polacca Wash (09400568), Black Mesa area, Arizona. A, Annual average discharge for calendar years 1977-99. B, Median discharge for November, December, January, and February for water years 1977-99. 
The median discharges for November, December, January, and February for the four gaging stations have much less year-to-year variability than the annual average discharges (fig. 10). This difference in variability is expected because the median flows are mostly ground-water discharge, which varies a small amount each year, and the annual average discharges are mostly controlled by precipitation, which varies considerably each year.

In water year 1999, median flows for November, December, January, and February were $3.0 \mathrm{ft}^{3} / \mathrm{s}$ for Moenkopi Wash, $3.6 \mathrm{ft}^{3} / \mathrm{s}$ for Laguna Creek, $0.45 \mathrm{ft}^{3} / \mathrm{s}$ for Dinnebito Wash, and $0.22 \mathrm{ft}^{3} / \mathrm{s}$ for Polacca Wash. Increasing or decreasing trends are not apparent in the median flows for all four gaging stations for the periods of record (fig. 10).

\section{Water Chemistry}

Water samples are collected from selected wells and springs each year of the Black Mesa monitoring program. Field measurements are made and water samples are analyzed for major ions, nutrients, iron, boron, and arsenic. During the past 10 years, water samples have been collected from about 30 wells and 10 springs. Each year of the program, samples are collected from about 12 wells and 4 springs. Long-term data for specific conductance, dissolved solids, chloride, and sulfate for the wells and springs sampled each year are shown in the report published each year. Historical data for other constituents for all the wells and springs are available from the USGS water-quality data base or can be found in past reports.

\section{Water from Wells Completed in the N Aquifer}

In 1999, water samples were collected from 12 wells completed in the $\mathrm{N}$ aquifer. Ten of the wells are in confined parts of the aquifer, one well (Dennehotso PM2) is in an unconfined part, and one well (Red Lake PM1) is on the boundary between the confined and unconfined parts (fig. 9).

The primary types of water in the $\mathrm{N}$ aquifer are calcium bicarbonate and sodium bicarbonate. Calcium bicarbonate water generally is in the recharge areas of the northern and northwestern parts of the Black Mesa area, and sodium bicar- bonate water is in the area that is downgradient to the south and east. This distribution was found in the water samples collected from the
12 wells in 1999; samples from Kayenta PM2 in the north and from Red Lake PM1 in the northwest were calcium bicarbonate water and samples from the other 10 wells were sodium bicarbonate water (figs. 11 and 12).

Dissolved-solids concentrations in water from the 12 wells ranged from $91 \mathrm{mg} / \mathrm{L}$ at Red Lake PM1 to $630 \mathrm{mg} / \mathrm{L}$ at Rough Rock PM5 (table 13, fig. 12). Two of the 12 wells had high concentrations of dissolved solids and chloride. Keams Canyon PM2 had a dissolved-solids concentration of $595 \mathrm{mg} / \mathrm{L}$ and a chloride concentration of $97 \mathrm{mg} / \mathrm{L}$, and Rough Rock PM5 had a dissolved- solids concentration of $630 \mathrm{mg} / \mathrm{L}$ and a chloride concentration of $130 \mathrm{mg} / \mathrm{L}$.

Concentrations of dissolved solids in water samples from the other 10 wells ranged from 91 to $274 \mathrm{mg} / \mathrm{L}$, and concentrations of chloride ranged from 1.4 to 16 mg.L. The areal distribution of dissolved solids generally was similar to the distribution of water types. Lower concentrations of dissolved solids are in the recharge areas of the north and northwest, and higher concentrations of dissolved solids are in the areas to the south and east (fig. 12).

Water-chemistry data are available for nine wells and four springs from about the mid-1980s (table 14; fig. 13). For that time period, the data from those sites have remained fairly stable. In eight of the wells, small year-to-year variations occurred in concentrations of dissolved solids, chloride, and sulfate; however, increasing or decreasing trends are not apparent. In the Forest Lake NTUA well, the chemistry of water samples has varied considerably between 1982 and 1999. Concentrations of dissolved solids, chloride, and sulfate increased from 1982 to 1997 and decreased in 1998 and 1999.

Comparison of the water samples from the 12 wells with U.S. Environmental Protection Agency (USEPA) Primary and Secondary Drinking-Water Regulations showed that the concentrations of most of the analyzed constituents were below Maximum Contaminant Levels (MCLs) and Secondary Maximum Contaminant Levels (SMCLs; U.S. Environmental Protection Agency, 2000). pH, however, exceeded the SMCL in samples from 10 of the 12 wells. The upper SMCL for $\mathrm{pH}$ is 8.5 units (table 13). SMCLs provide guidelines for the control of contaminants that may cause cosmetic effects (such as skin or tooth discoloration) or aesthetic effects (such as taste, odor, or color) in drinking water. The USEPA recommends SMCLs for water systems; however, compliance with these SMCLs is not mandatory. 


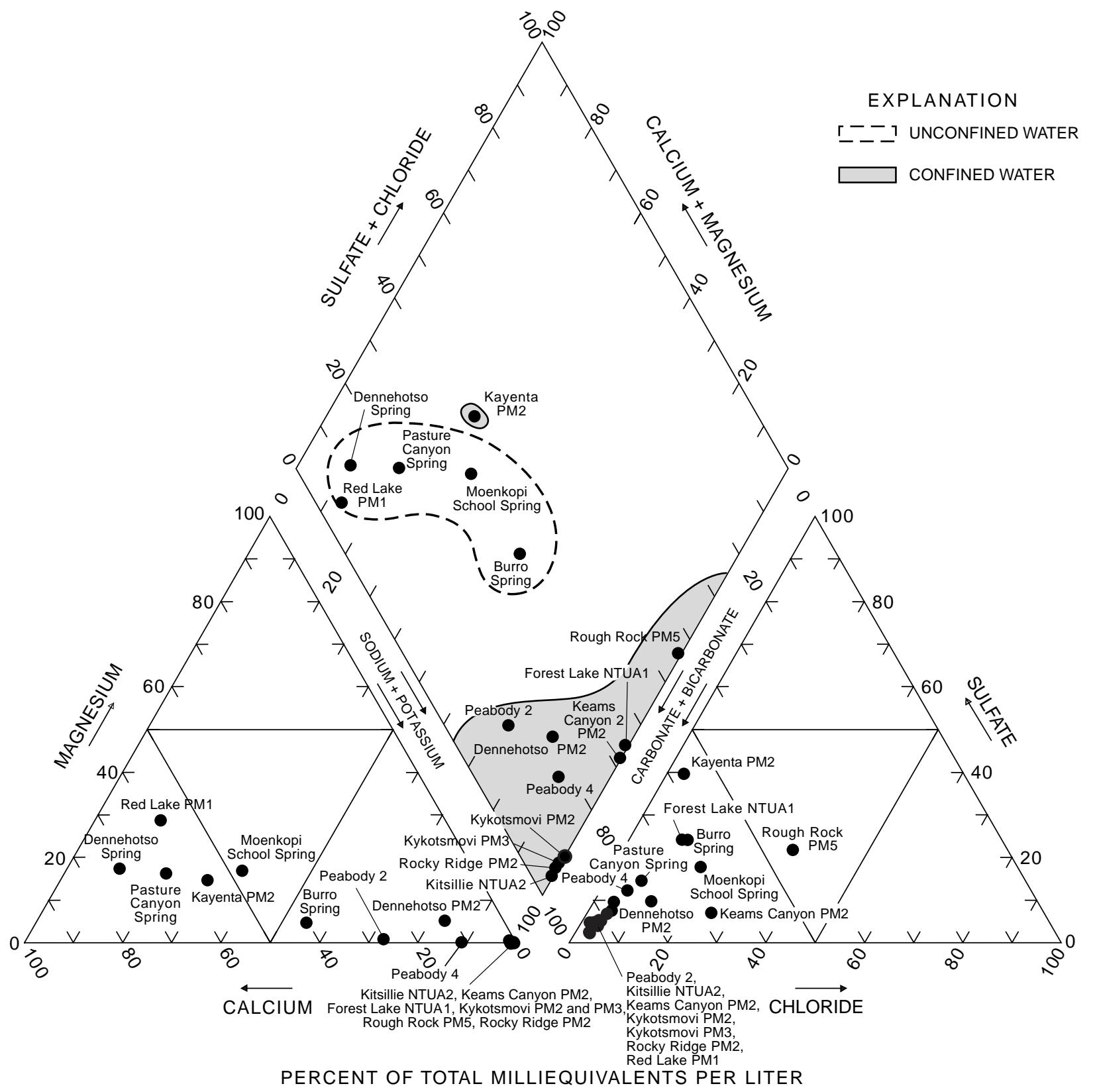

Figure 11. Relative compositions of ground water from the $\mathrm{N}$ aquifer, Black Mesa area, Arizona, 1999. 


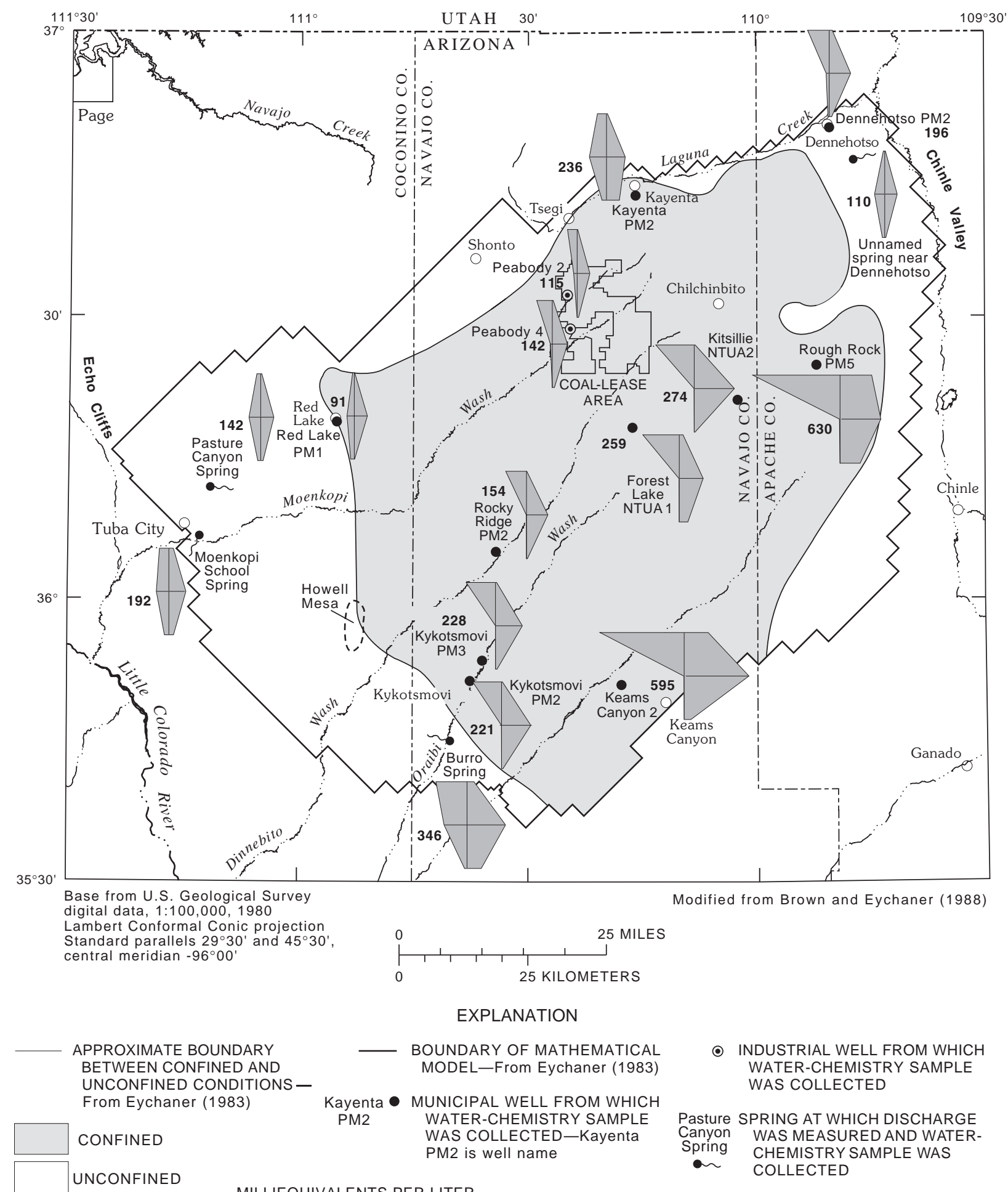

MILLIEQUIVALENTS PER LITER

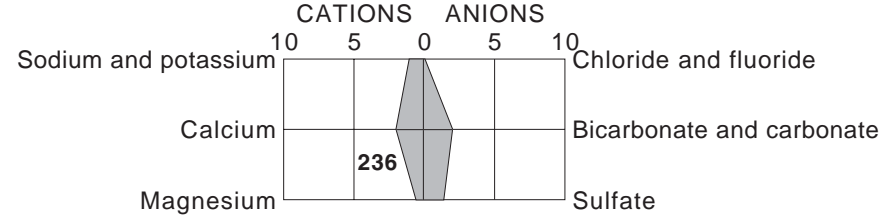

WATER-CHEMISTRY DIAGRAM - Shows major chemical constituents in milliequivalents per liter. The diagrams are in a variety of shapes and sizes, and provide a means of comparing, correlating, and characterizing types of water. Number, 236, is dissolved-solids concentration, in milligrams per liter

Figure 12. Water chemistry and distribution of dissolved solids in the N aquifer, Black Mesa area, Arizona, 1999. 
Table 13. Physical properties and chemical analyses of water from selected industrial and municipal wells completed in the $\mathrm{N}$ aquifer, Black Mesa area, Arizona, 1999

$\left[{ }^{\circ} \mathrm{C}\right.$, degrees Celsius; $\mu \mathrm{S} / \mathrm{cm}$, microsiemens per centimeter at $25^{\circ} \mathrm{C} ; \mathrm{mg} / \mathrm{L}$, milligrams per liter; $\mu \mathrm{g} / \mathrm{L}$, micrograms per liter; $<$, less than.

Dashes indicate no data]

\begin{tabular}{|c|c|c|c|c|c|c|c|c|c|c|c|c|}
\hline Well name & \multicolumn{2}{|c|}{$\begin{array}{l}\text { U.S. Geological } \\
\text { Survey } \\
\text { identification } \\
\text { number }\end{array}$} & \multicolumn{2}{|c|}{$\begin{array}{l}\text { Date of } \\
\text { sample }\end{array}$} & $\begin{array}{l}\text { Temper } \\
\text { ature, } \\
\text { field } \\
\left({ }^{\circ} \mathrm{C}\right)\end{array}$ & $\begin{array}{c}\text { Specific } \\
\text { conduc- } \\
\text { tance, } \\
\text { field } \\
(\mu \mathrm{S} / \mathrm{cm})\end{array}$ & $\begin{array}{c}\mathrm{pH}, \\
\text { field } \\
\text { (units) }\end{array}$ & $\begin{array}{l}\text { Alkalinity, } \\
\text { field } \\
\text { (mg/L as } \\
\left.\mathrm{CaCO}_{3}\right)\end{array}$ & $\begin{array}{c}\text { Nitrogen } \\
\mathrm{NO}_{2}+\mathrm{NO}_{3} \\
\text { dissolved } \\
\text { (mg/L as } \mathrm{N} \text { ) }\end{array}$ & $\begin{array}{l}\text { Phos- } \\
\text { phorus, } \\
\text { ortho, } \\
\text { dissolved } \\
\text { (mg/L as } \\
\text { P) }\end{array}$ & $\begin{array}{c}\text { Calcium, } \\
\text { dissolved } \\
\text { (mg/L as Ca) }\end{array}$ & $\begin{array}{c}\text { Magnesium, } \\
\text { dissolved } \\
(\mathrm{mg} / \mathrm{L} \text { as } \mathrm{Mg})\end{array}$ \\
\hline Dennehotso PM2 & \multicolumn{2}{|c|}{365045109504001} & \multicolumn{2}{|c|}{$12-15-99$} & --- & 314 & 9.1 & 140 & 1.5 & $<0.01$ & 7.8 & 1.9 \\
\hline Forest Lake NTUA1 & \multicolumn{2}{|c|}{361737110180301} & \multicolumn{2}{|c|}{$12-07-99$} & 28.0 & 380 & 9.4 & 140 & .57 & $<.01$ & .80 & .10 \\
\hline Kayenta PM2 & \multicolumn{2}{|c|}{364344110151201} & \multicolumn{2}{|c|}{$12-14-99$} & 15.5 & 364 & 8.0 & 110 & .95 & $<.01$ & 41 & 6.4 \\
\hline Keams Canyon PM2 & \multicolumn{2}{|c|}{355023110182701} & \multicolumn{2}{|c|}{ 12-09-99 } & 18.8 & 1,040 & 9.1 & 370 & $<.05$ & $<.01$ & .86 & .24 \\
\hline Kitsillie NTUA 2 & \multicolumn{2}{|c|}{362043110030501} & \multicolumn{2}{|c|}{$01-13-00$} & 28.8 & 454 & 9.2 & 220 & 1.4 & .07 & .53 & $<.014$ \\
\hline Kykotsmovi PM2 & \multicolumn{2}{|c|}{355215110375001} & \multicolumn{2}{|c|}{$12-06-99$} & 22.5 & 317 & 9.7 & 170 & 1.2 & .04 & .50 & .03 \\
\hline Kykotsmovi PM3 & \multicolumn{2}{|c|}{355236110364501} & \multicolumn{2}{|c|}{$12-06-99$} & 22.1 & 340 & 9.7 & 160 & 1.2 & .02 & .33 & $<.014$ \\
\hline Peabody 2 & \multicolumn{2}{|c|}{363005110250901} & \multicolumn{2}{|c|}{ 12-16-99 } & 30.6 & 167 & 8.6 & 78 & .99 & $<.01$ & 8.6 & .13 \\
\hline Peabody 4 & \multicolumn{2}{|c|}{362901110234101} & \multicolumn{2}{|c|}{$12-16-99$} & 31.3 & 216 & 9.0 & 90 & 1.0 & $<.01$ & 4.5 & .03 \\
\hline Red Lake PM1 & \multicolumn{2}{|c|}{360527110122501} & \multicolumn{2}{|c|}{$12-13-99$} & 16.3 & 153 & 8.2 & 78 & 1.3 & $<.01$ & 17 & 5.2 \\
\hline Rocky Ridge PM2 & 36041811 & 352701 & $12-$ & $8-99$ & 26.6 & 241 & 9.4 & 120 & 1.3 & .02 & .40 & $<.014$ \\
\hline Rough Rock PM5 & 36241810 & 514601 & $12-$ & 4-99 & 20.7 & 1,050 & 8.9 & 230 & 1.0 & .02 & 1.9 & .26 \\
\hline Well name & $\begin{array}{c}\text { Sodium, } \\
\text { dissolved } \\
\text { (mg/L as } \\
\mathrm{Na})\end{array}$ & $\begin{array}{r}\text { Potass } \\
\text { dissol } \\
\text { (mg/L a }\end{array}$ & & $\begin{array}{r}\text { Chlor } \\
\text { disso } \\
\text { (mg } \\
\text { as }\end{array}$ & $\begin{array}{l}\text { ride, } \\
\text { lved } \\
\text { g/L } \\
\text { CI) }\end{array}$ & $\begin{array}{c}\text { Sulfate, } \\
\text { dissolved } \\
\text { (mg/L as } \\
\left.\mathrm{SO}_{4}\right)\end{array}$ & $\begin{array}{c}\text { Fluoride } \\
\text { dissolved } \\
\text { (mg/L } \\
\text { as F) }\end{array}$ & $\begin{array}{c}\text { Silica, } \\
\text { dissolved } \\
(\mathrm{mg} / \mathrm{L} \text { as } \\
\left.\mathrm{SiO}_{2}\right)\end{array}$ & $\begin{array}{cc} & \begin{array}{c}\text { Arsenic, } \\
\text { d } \\
\text { dissolved } \\
(\mu \mathrm{g} / \mathrm{L}\end{array} \\
\text { as As })\end{array}$ & $\begin{array}{c}\text { Boron, } \\
\text { dissolved } \\
(\mu \mathrm{g} / \mathrm{L} \\
\text { as B })\end{array}$ & $\begin{array}{c}\text { Iron, } \\
\text { dissolved } \\
(\mu \mathrm{g} / \mathrm{L} \\
\text { as Fe) }\end{array}$ & $\begin{array}{c}\text { Dissolved } \\
\text { solids, } \\
\text { residue at } \\
180^{\circ} \mathrm{C}(\mathrm{mg} / \mathrm{L})\end{array}$ \\
\hline Dennehotso PM2 & 62 & 0.69 & & 14 & & 15 & 0.16 & 13 & 6 & 38 & $<10$ & 196 \\
\hline Forest Lake NTUA1 & 97 & .61 & & 16 & & 49 & .42 & 23 & 3 & 125 & 55 & 259 \\
\hline Kayenta PM2 & 25 & 1.1 & & 4. & & 72 & .11 & 18 & 2 & 23 & $<10$ & 236 \\
\hline Keams Canyon PM2 & 223 & .76 & & 97 & & 35 & 1.5 & 13 & 40 & 642 & $<10$ & 595 \\
\hline Kitsillie NTUA 2 & 97 & .55 & & $4 .($ & & 4.1 & .22 & 28 & 4 & 47 & $<10$ & 274 \\
\hline Kykotsmovi PM2 & 78 & .35 & & 3. & & 7.9 & .16 & 27 & 5 & 27 & $<10$ & 221 \\
\hline Kykotsmovi PM3 & 81 & .35 & & 4. & & 9.1 & .21 & 26 & 7 & 35 & $<10$ & 228 \\
\hline Peabody 2 & 27 & .68 & & 2. & & 8.1 & $<.10$ & 24 & 3 & $<16$ & $<10$ & 115 \\
\hline Peabody 4 & 42 & .63 & & $4 .($ & & 13 & .15 & 24 & 3 & 18 & $<10$ & 142 \\
\hline Red Lake PM1 & 4.4 & 1.9 & & 1. & & 2.1 & .13 & 12 & $<.9$ & $<16$ & $<10$ & 91 \\
\hline Rocky Ridge PM2 & 54 & .39 & & 1. & & 5.3 & .11 & 22 & 3 & 20 & $<10$ & 154 \\
\hline Rough Rock PM5 & 230 & 1.2 & & 130 & & 110 & 1.7 & 13 & 48 & 401 & 16 & 630 \\
\hline
\end{tabular}


Table 14. Specific conductance and concentrations of selected chemical constituents in water from industrial and municipal wells completed in the $\mathrm{N}$ aquifer, Black Mesa area, Arizona, 1964-99

[ $\mu \mathrm{S} / \mathrm{cm}$, microsiemens per centimeter at $25^{\circ} \mathrm{C} ;{ }^{\circ} \mathrm{C}$, degrees Celsius; $\mathrm{mg} / \mathrm{L}$, milligrams per liter. Dashes indicate no data]

\begin{tabular}{|c|c|c|c|c|c|c|c|c|c|}
\hline Year & $\begin{array}{c}\text { Specific } \\
\text { conductance, } \\
\text { field }(\mu S / \mathrm{cm})\end{array}$ & $\begin{array}{c}\text { Dissolved } \\
\text { solids, residue } \\
\text { at } 180^{\circ} \mathrm{C}(\mathrm{mg} / \mathrm{L})\end{array}$ & $\begin{array}{c}\text { Chloride, } \\
\text { dissolved } \\
\text { (mg/L as CI) }\end{array}$ & $\begin{array}{c}\text { Sulfate, } \\
\text { dissolved } \\
\text { (mg/L as } \\
\left.\mathrm{SO}_{4}\right)\end{array}$ & Year & $\begin{array}{c}\text { Specific } \\
\text { conductance, } \\
\text { field }(\mu \mathrm{S} / \mathrm{cm})\end{array}$ & $\begin{array}{c}\text { Dissolved } \\
\text { solids, } \\
\text { residue at } \\
180^{\circ} \mathrm{C} \text { (mg/L) }\end{array}$ & $\begin{array}{l}\text { Chloride, } \\
\text { dissolved } \\
\text { (mg/L as CI) }\end{array}$ & $\begin{array}{c}\text { Sulfate, } \\
\text { dissolved } \\
\text { (mg/L as } \\
\left.\mathrm{SO}_{4}\right)\end{array}$ \\
\hline \multicolumn{5}{|c|}{ Dinnehotso PM2 } & \multicolumn{5}{|c|}{ Keams Canyon PM2--Continued } \\
\hline 1964 & 350 & --- & 12 & 31 & 1990 & 1,030 & 600 & 94 & 34 \\
\hline 1992 & 226 & 131 & 9.8 & 19 & 1992 & ${ }^{1} 1,010$ & 570 & 93 & 36 \\
\hline 1993 & 298 & 164 & 8.2 & 16 & 1993 & 1,040 & 590 & 92 & 36 \\
\hline 1997 & 1305 & 190 & 11 & 14 & 1994 & 1975 & 562 & 86 & 32 \\
\hline 1999 & 314 & 196 & 14 & 15 & 1995 & 1,010 & 606 & 99 & 32 \\
\hline \multicolumn{5}{|c|}{ Forest Lake NTUA 1} & 1996 & 1,030 & 596 & 96 & 34 \\
\hline 1982 & 470 & --- & 11 & 67 & 1997 & ${ }^{1} 1,070$ & 590 & 96 & 33 \\
\hline 1990 & 375 & 226 & 8.2 & 38 & 1998 & 908 & 558 & 78 & 29 \\
\hline 1991 & 1350 & 183 & 10 & 24 & 1999 & 1,040 & 595 & 97 & 35 \\
\hline 1993 & 693 & 352 & 35 & 88 & \multicolumn{5}{|c|}{ Kitsillie NTUA 2} \\
\hline 1994 & 1734 & 430 & 56 & 100 & 1997 & ${ }^{1524}$ & 269 & 3.6 & 4.3 \\
\hline 1995 & 470 & 274 & 13 & 60 & 1998 & 379 & 270 & 3.8 & 4.1 \\
\hline Do & 1,030 & 626 & 86 & 160 & 1999 & 454 & 274 & 4.0 & 4.1 \\
\hline Do & 488 & 316 & 16 & 71 & \multicolumn{5}{|c|}{ Kykotsmovi PM2 } \\
\hline 1996 & 684 & 368 & 44 & 79 & 1988 & 368 & 212 & 3.2 & 8.6 \\
\hline 1997 & ${ }^{1} 1,140$ & 714 & 78 & 250 & 1990 & 355 & 255 & 3.2 & 9.0 \\
\hline 1998 & 489 & 350 & 37 & 71 & 1991 & 1374 & 203 & 4.4 & 7.9 \\
\hline 1999 & 380 & 259 & 16 & 49 & 1992 & 363 & 212 & 3.3 & 8.4 \\
\hline \multicolumn{5}{|c|}{ Kayenta PM2 } & 1994 & 1365 & 212 & 3.6 & 8.5 \\
\hline 1982 & 360 & $\left({ }^{2}\right)$ & 4.5 & 58 & 1995 & 368 & 224 & 3.1 & 6.2 \\
\hline 1983 & 375 & $\left({ }^{2}\right)$ & 5.9 & 60 & 1996 & 365 & 224 & 3.3 & 8.5 \\
\hline 1984 & 1370 & 209 & 4.2 & 51 & 1997 & 1379 & 222 & 3.0 & 8.0 \\
\hline 1986 & 300 & 181 & 8.2 & 30 & 1998 & 348 & 223 & 3.3 & 7.3 \\
\hline 1988 & 358 & 235 & 3.8 & 74 & 1999 & 317 & 221 & 3.5 & 7.9 \\
\hline 1992 & 383 & 210 & 5.6 & 78 & \multicolumn{5}{|c|}{ Kykotsmovi PM3 } \\
\hline 1993 & 374 & 232 & 3.7 & 78 & 1998 & 341 & 219 & 4.6 & 8.4 \\
\hline 1994 & 1371 & 236 & 4.2 & 77 & 1999 & 340 & 228 & 4.3 & 9.1 \\
\hline 1995 & 371 & 250 & 4.2 & 72 & \multicolumn{5}{|c|}{ Peabody 2} \\
\hline 1996 & 370 & 238 & 3.8 & 76 & 1980 & 225 & 145 & 11 & 20 \\
\hline 1997 & 1379 & 230 & 3.9 & 77 & 1986 & 172 & --- & 2.6 & 8.1 \\
\hline 1998 & 349 & 236 & 3.7 & 71 & 1987 & 149 & 113 & 5.0 & 9.1 \\
\hline 1999 & 364 & 236 & 4.0 & 72 & 1993 & 163 & 124 & 1.7 & 8.9 \\
\hline \multicolumn{5}{|c|}{ Keams Canyon PM2 } & 1998 & 93 & 119 & 2.2 & 7.9 \\
\hline 1982 & 1,010 & $\left({ }^{2}\right)$ & 94 & 35 & 1999 & 167 & 115 & 2.3 & 8.1 \\
\hline 1983 & 1,120 & $\left({ }^{2}\right)$ & 120 & 42 & \multicolumn{5}{|c|}{ Peabody 4} \\
\hline 1984 & ${ }^{1} 1,060$ & 578 & 96 & 36 & 1974 & 200 & 140 & 3.8 & 13 \\
\hline 1988 & 1,040 & 591 & 97 & 34 & 1975 & 220 & 144 & 3.4 & 13 \\
\hline
\end{tabular}


Table 14. Specific conductance and concentrations of selected chemical constituents in water from industrial and municipal wells completed in the N aquifer, Black Mesa area, Arizona, 1964-99_Continued

\begin{tabular}{|c|c|c|c|c|c|c|c|c|c|}
\hline Year & $\begin{array}{c}\text { Specific } \\
\text { conductance, } \\
\text { field }(\mu \mathrm{S} / \mathrm{cm})\end{array}$ & $\begin{array}{c}\text { Dissolved } \\
\text { solids, residue } \\
\text { at } 180^{\circ} \mathrm{C}(\mathrm{mg} / \mathrm{L})\end{array}$ & $\begin{array}{c}\text { Chloride, } \\
\text { dissolved } \\
\text { (mg/L as CI) }\end{array}$ & $\begin{array}{c}\text { Sulfate, } \\
\text { dissolved } \\
\text { (mg/L as } \\
\left.\mathrm{SO}_{4}\right)\end{array}$ & Year & $\begin{array}{c}\text { Specific } \\
\text { conductance, } \\
\text { field }(\mu \mathrm{S} / \mathrm{cm})\end{array}$ & $\begin{array}{l}\text { Dissolved } \\
\text { solids, } \\
\text { residue at } \\
180^{\circ} \mathrm{C} \text { (mg/L) }\end{array}$ & $\begin{array}{c}\text { Chloride, } \\
\text { dissolved } \\
\text { (mg/L as Cl) }\end{array}$ & $\begin{array}{c}\text { Sulfate, } \\
\text { dissolved } \\
\text { (mg/L as } \\
\left.\mathrm{SO}_{4}\right)\end{array}$ \\
\hline \multicolumn{5}{|c|}{ Peabody 4 -Continued } & \multicolumn{5}{|c|}{ Rocky Ridge PM2 } \\
\hline 1976 & 240 & 138 & 2.9 & 19 & 1986 & 247 & 164 & 2.4 & 6.4 \\
\hline 1979 & 220 & --- & 3.9 & 19 & 1998 & 215 & 140 & 1.4 & $<.10$ \\
\hline 1980 & 230 & 139 & 4.3 & 13 & 1999 & 241 & 154 & 1.4 & 5.3 \\
\hline 1986 & 205 & --- & 4.2 & 12 & \multicolumn{5}{|c|}{ Rough Rock PM5 } \\
\hline 1987 & 194 & 135 & ${ }^{3} 5.0$ & 13 & 1983 & 1,090 & $\left({ }^{2}\right)$ & 130 & 110 \\
\hline 1992 & 224 & 125 & 4.3 & 12 & 1984 & ${ }^{1} 1,100$ & 613 & 130 & 99 \\
\hline 1993 & 214 & 124 & 33.0 & 12 & 1986 & 1,010 & 633 & 140 & 120 \\
\hline 1996 & 214 & 140 & 3.8 & 12 & 1988 & 1,120 & 624 & 130 & ${ }^{3} 110$ \\
\hline 1997 & ${ }^{1} 203$ & 139 & 3.5 & 12 & 1991 & ${ }^{1} 1,210$ & 574 & 130 & 110 \\
\hline 1999 & 216 & 142 & 4.0 & 13 & 1993 & 1,040 & 614 & 130 & 110 \\
\hline \multicolumn{5}{|c|}{ Red Lake PM1 } & 1994 & ${ }^{1} 1,070$ & 626 & 130 & 110 \\
\hline 1992 & 164 & 87 & 2.6 & 1.9 & 1995 & 1,110 & 648 & 140 & 110 \\
\hline 1993 & 156 & 84 & 1.6 & 2.1 & 1996 & 1,100 & 634 & 130 & 110 \\
\hline 1995 & 157 & 92 & 1.6 & 2.0 & 1997 & ${ }^{1} 1,060$ & 628 & 130 & 110 \\
\hline 1997 & ${ }^{1} 156$ & 96 & 3.2 & 1.7 & 1998 & 894 & 637 & 130 & 110 \\
\hline 1999 & 153 & 91 & 1.6 & 2.1 & 1999 & 1,050 & 630 & 130 & 110 \\
\hline
\end{tabular}

${ }^{1}$ Value shown in Black Mesa monitoring reports from previous years for this date is different. The earlier reports showed values determined by laboratory analysis.

${ }^{2}$ Value shown in Black Mesa monitoring reports from previous years for this date is different. The earlier reports showed values determined by the sum of constituents.

${ }^{3}$ Value shown in Black Mesa monitoring reports from previous years for this date is different. The earlier reports applied a different rounding method.

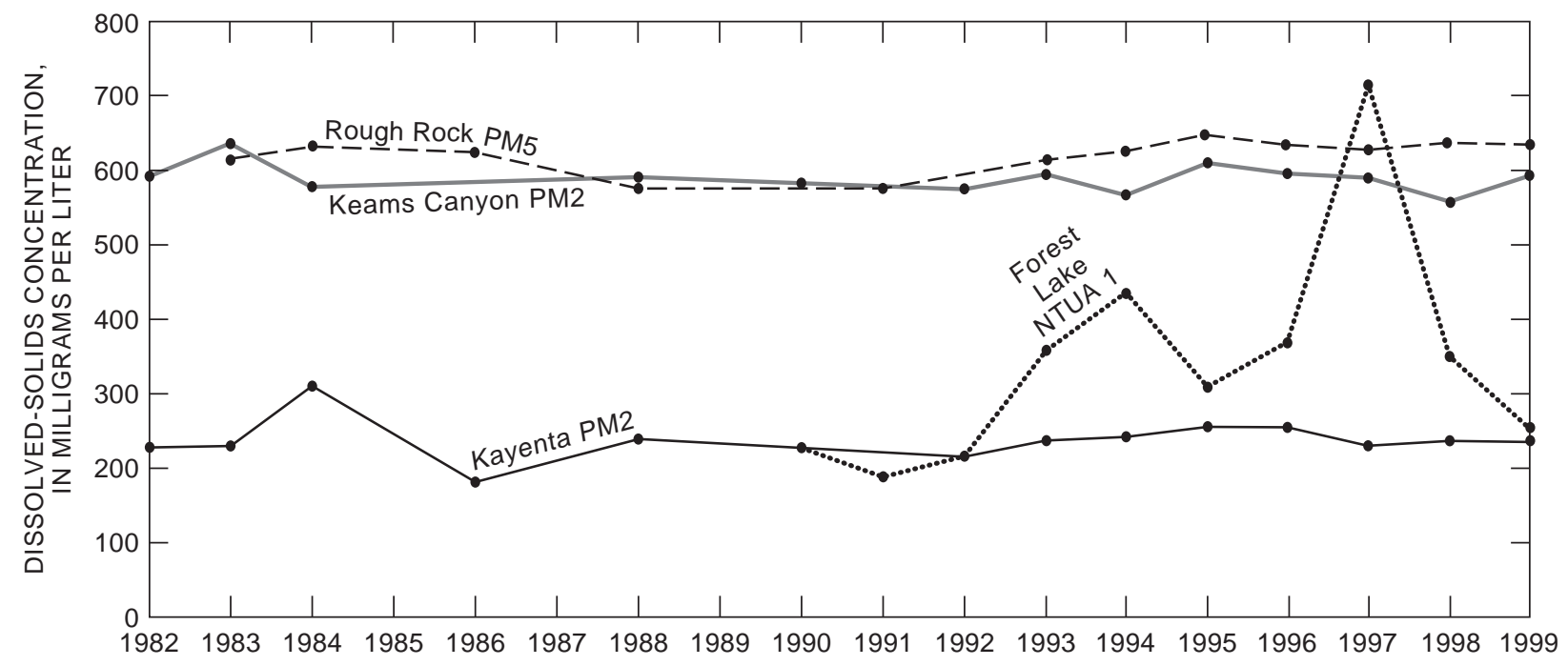

Figure 13. Dissolved-solids concentrations in water from wells Keams Canyon PM2, Rough Rock PM5, Forest Lake NTUA 1, and Kayenta PM2, Black Mesa area, Arizona, 1982-99. 
Samples from two of the 12 wells had concentrations of other constituents that exceeded an SMCL and a proposed MCL. The water samples from Keams Canyon PM2 and Rough Rock PM5 had dissolved-solids concentrations higher than the applicable SMCL (500 mg/L; table 13). Those two water samples also had high concentrations of arsenic. The sample from Keams Canyon PM2 had a concentration of $40 \mu \mathrm{g} / \mathrm{L}$, and the sample from Rough Rock PM5 had a concentration of $48 \mu \mathrm{g} / \mathrm{L}$. The existing USEPA MCL for arsenic is $50 \mu \mathrm{g} / \mathrm{L}$; however, the USEPA has proposed a new standard of $5 \mu \mathrm{g} / \mathrm{L}$. The new MCL for arsenic will become effective on January 1, 2001, after a comment period from June 22, 2000, to January 1, 2001. The new MCL for arsenic may not be $5 \mu \mathrm{g} / \mathrm{L}$; however, there is a high probability that it will be closer to $5 \mu \mathrm{g} / \mathrm{L}$ than to $50 \mu \mathrm{g} / \mathrm{L}$. MCLs established by the USEPA are legally enforceable standards.

\section{Water from Springs that Discharge from the N Aquifer}

In 1999, water samples were collected from four springs in the study area. Burro Spring is on the south side of the study area, an unnamed spring near Dennehotso is on the northeast side, and Moenkopi
School Spring and Pasture Canyon Spring are on the west side (fig. 9). All the springs discharge water from the unconfined part of the $\mathrm{N}$ aquifer.

Water samples from three of the springs- Pasture Canyon Spring, Moenkopi School Spring, and an unnamed spring near Dennehotso-were a calcium carbonate type and had low dissolved- solids concentrations (110 to192 mg/L). The water sample from Burro Spring was a sodium carbonate type and had a much higher dissolved-solids concentration of $346 \mathrm{mg} / \mathrm{L}$ (table 15, fig. 12). Concentrations of analyzed constituents in samples from the four springs were below current MCLs and SMCLs (U.S. Environmental Protection Agency, 2000).

From the early 1980 s to 1999 , trends were not apparent in the concentrations of dissolved solids, chloride, and sulfate in water samples from Burro Spring, an unnamed spring near Dennehotso, and Pasture Canyon Spring. From 1987 to 1999, a slight increasing trend is apparent in the concentrations of those constituents in water samples from Moenkopi School Spring (table 16).

Table 15. Physical properties and chemical analyses of water from selected springs that discharge from the N aquifer, Black Mesa area, Arizona, 1999

$\left[{ }^{\circ} \mathrm{C}\right.$, degree Celsius; $\mu \mathrm{S} / \mathrm{cm}$, microsiemens per centimeter at $25^{\circ} \mathrm{C} ; \mathrm{mg} / \mathrm{L}$, milligrams per liter; $\mu \mathrm{g} / \mathrm{L}$, micrograms per liter; <, less than. Dashes indicate no data]

\begin{tabular}{|c|c|c|c|c|c|c|c|c|c|c|}
\hline Spring name & $\begin{array}{l}\text { Bureau of } \\
\text { Indian } \\
\text { Affairs } \\
\text { site number }\end{array}$ & $\begin{array}{l}\text { U.S. Geological } \\
\text { Survey } \\
\text { identification } \\
\text { number }\end{array}$ & Rock formation & $\begin{array}{l}\text { Date of } \\
\text { sample }\end{array}$ & $\begin{array}{c}\text { Temper } \\
\text {-ature } \\
\left({ }^{\circ} \mathrm{C}\right)\end{array}$ & $\begin{array}{c}\text { Specifi } \\
\text { c } \\
\text { conduct } \\
\text {-ance, } \\
\text { field } \\
(\mu \mathrm{S} / \mathrm{cm})\end{array}$ & $\underset{\text { (units) }}{\mathrm{pH}}$ & $\begin{array}{l}\text { Alkalinit } \\
y(\mathrm{mg} / \mathrm{L} \\
\text { as } \\
\left.\mathrm{CaCO}_{3}\right)\end{array}$ & $\begin{array}{c}\text { Nitrogen, } \\
\mathrm{NO}_{2}+\mathrm{NO}_{3} \\
\text { ' } \\
\text { dissolve } \\
\mathrm{d}(\mathrm{mg} / \mathrm{L} \\
\text { as } \mathrm{N})\end{array}$ & $\begin{array}{l}\text { Phos- } \\
\text { phorus, } \\
\text { ortho, } \\
\text { dissolved } \\
\text { (mg/L } \\
\text { as } \mathrm{P} \text { ) }\end{array}$ \\
\hline Burro Spring & $6 \mathrm{M}-31$ & 354156110413701 & Navajo Sandstone & $12-07-99$ & --- & 545 & 8.1 & 190 & 0.27 & $<0.01$ \\
\hline $\begin{array}{l}\text { Unnamed spring } \\
\text { near Dennehotso }\end{array}$ & $8 A-224$ & 364656109425400 & Navajo Sandstone & $12-15-99$ & 7.7 & 184 & 7.8 & 80 & 1.6 & .01 \\
\hline $\begin{array}{l}\text { Moenkopi School } \\
\text { Spring }\end{array}$ & $3 G S-77-6$ & 360632111131101 & $\begin{array}{l}\text { Navajo Sandstone } \\
\text { tongue in the } \\
\text { Kayenta Formation }\end{array}$ & $12-13-99$ & 17.5 & 305 & 7.6 & --- & 2.4 & $<.01$ \\
\hline $\begin{array}{l}\text { Pasture Canyon } \\
\text { Spring }\end{array}$ & $3 A-5$ & 361021111115901 & Navajo Sandstone & $12-21-99$ & 15.3 & 235 & 7.7 & 81 & 4.6 & .02 \\
\hline
\end{tabular}


Table 15. Physical properties and chemical analyses of water from selected springs that discharge from the $\mathrm{N}$ aquifer, Black Mesa area, Arizona, 1999-Continued

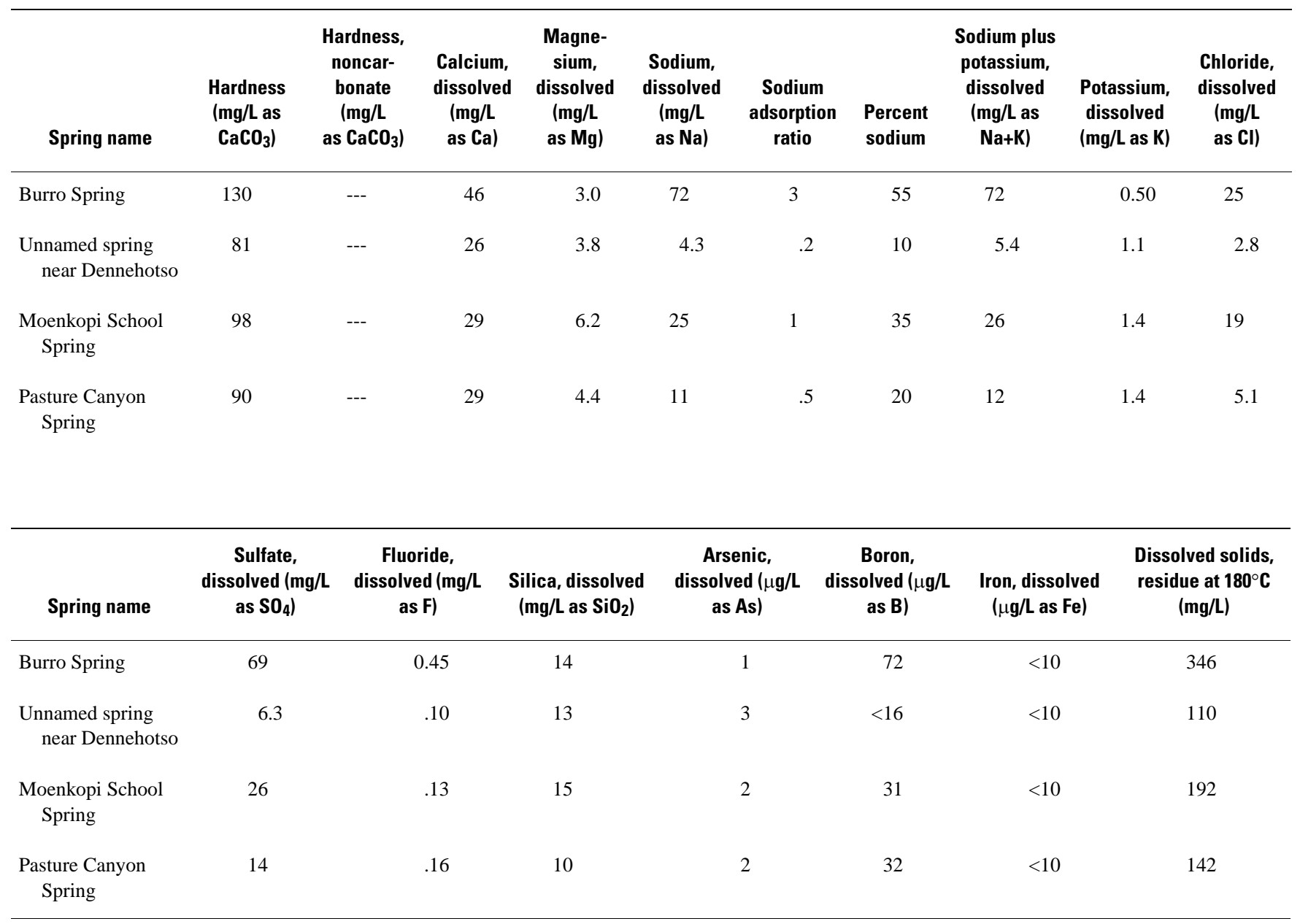

Table 16. Specific conductance and concentrations of selected chemical constituents in water from selected springs that discharge from the N aquifer, Black Mesa area, Arizona, 1948-99

[ $\mu \mathrm{S} / \mathrm{cm}$, microsiemens per centimeter at $25^{\circ} \mathrm{C} ; \mathrm{mg} / \mathrm{L}$, milligrams per liter; ${ }^{\circ} \mathrm{C}$, degrees Celsius. Dashes indicate no data]

\begin{tabular}{ccccc}
\hline Year & $\begin{array}{c}\text { Specific conductance, } \\
\text { field (mS/cm) }\end{array}$ & $\begin{array}{c}\text { Dissolved solids, } \\
\text { residue at 180xC } \\
\text { (mg/L) }\end{array}$ & $\begin{array}{c}\text { Chloride, dissolved } \\
\text { (mg/L as CI) }\end{array}$ & $\begin{array}{c}\text { Sulfate, dissolved } \\
\text { (mg/L as S04) }\end{array}$ \\
\hline 1989 & Burro Spring & & \\
1990 & 485 & 308 & 22 & 59 \\
1993 & 1545 & 347 & 30 & 65 \\
1994 & 595 & 368 & 26 & 80 \\
1996 & 1597 & 368 & 23 & 62 \\
1997 & 525 & 324 & 26 & 75 \\
1998 & 1511 & 332 & 25 & 70 \\
1999 & 504 & 346 & 25 & 69
\end{tabular}

See footnotes at end of table. 
Table 16. Specific conductance and concentrations of selected chemical constituents in water from selected springs that discharge from the $\mathrm{N}$ aquifer, Black Mesa area, Arizona, 1948-99_-Continued

\begin{tabular}{|c|c|c|c|c|}
\hline Year & $\begin{array}{l}\text { Specific conductance, } \\
\text { field }(\mathrm{mS} / \mathrm{cm})\end{array}$ & $\begin{array}{l}\text { Dissolved solids, } \\
\text { residue at } 180 \times C \\
\text { (mg/L) }\end{array}$ & $\begin{array}{l}\text { Chloride, dissolved } \\
\text { (mg/L as CI) }\end{array}$ & $\begin{array}{l}\text { Sulfate, dissolved } \\
\text { (mg/L as S04) }\end{array}$ \\
\hline \multicolumn{5}{|c|}{ Unnamed spring near Dennehotso } \\
\hline 1984 & 195 & 112 & 2.8 & 7.1 \\
\hline 1987 & 178 & ${ }^{2} 109$ & 3.4 & 7.5 \\
\hline 1992 & 178 & 108 & 3.6 & 7.3 \\
\hline 1993 & 184 & 100 & 3.2 & 8 \\
\hline 1995 & 184 & 124 & 2.6 & 5.7 \\
\hline 1996 & 189 & 112 & 2.8 & 8.2 \\
\hline 1997 & ${ }^{1} 170$ & 98 & 2.4 & 6.1 \\
\hline 1998 & 179 & 116 & 2.4 & 5.4 \\
\hline 1999 & 184 & 110 & 2.8 & 6.3 \\
\hline \multicolumn{5}{|c|}{ Moenkopi School Spring } \\
\hline 1952 & 222 & --- & 6 & --- \\
\hline 1987 & 270 & 161 & 12 & 19 \\
\hline 1988 & 270 & 155 & 12 & 19 \\
\hline 1991 & 297 & 157 & 14 & 20 \\
\hline 1993 & 313 & 204 & 17 & 27 \\
\hline 1994 & 305 & 182 & 17 & 23 \\
\hline 1995 & 314 & 206 & 18 & 22 \\
\hline 1996 & 332 & 196 & 19 & 26 \\
\hline 1997 & ${ }^{1} 305$ & 185 & 18 & 24 \\
\hline 1998 & 296 & 188 & 18 & 24 \\
\hline 1999 & 305 & 192 & 19 & 26 \\
\hline \multicolumn{5}{|c|}{ Pasture Canyon Spring } \\
\hline 1948 & ${ }^{1} 227$ & $\left({ }^{2}\right)$ & 5 & 13 \\
\hline 1982 & 240 & --- & 5.1 & 18 \\
\hline 1986 & 257 & --- & 5.4 & 19 \\
\hline 1988 & 232 & 146 & 5.3 & 18 \\
\hline 1992 & 235 & 168 & 7.1 & 17 \\
\hline 1993 & 242 & 134 & 5.3 & 17 \\
\hline 1995 & 235 & 152 & 4.8 & 14 \\
\hline 1996 & 238 & 130 & 4.7 & 15 \\
\hline 1997 & 232 & 143 & 5.3 & 17 \\
\hline 1998 & 232 & 147 & 5.1 & 16 \\
\hline 1999 & 235 & 142 & 5.1 & 14 \\
\hline
\end{tabular}

\footnotetext{
${ }^{1}$ Value shown in Black Mesa monitoring reports from previous years for this date is different. The earlier reports showed values determined by laboratory analysis.

${ }^{2}$ Value shown in Black Mesa monitoring reports from previous years for this date is different. The earlier reports showed values determined by the sum of constituents.
} 


\section{SUMMARY}

The $\mathrm{N}$ aquifer is the major source of water for industrial and municipal users in the Black Mesa area of northeastern Arizona. Availability of water is an important issue in the Black Mesa area because of continued industrial and municipal use, a growing population, and a precipitation of only about 6 to 12 in./yr.

In 1999, total ground-water withdrawals were 7,110 acre-ft, industrial use was 4,210 acre-ft, and municipal use was 2,900 acre-ft. From 1998 to 1999, total withdrawals increased by 0.7 percent, industrial use increased by 4 percent, and municipal use decreased by 4 percent. During the past 10 years, total withdrawals and municipal and industrial use increased at an average rate of about 2 percent per year.

Flowmeters attached to 25 municipal wells were tested for accuracy with a test mechanical flowmeter. Twenty-four wells had flowmeter readings within 10 percent of the test meter. The flowmeter reading at one well was within 12.2 percent of the test-meter reading.

From 1998 to 1999, ground-water levels declined in 25 of 31 wells. The median water-level change in the 31 wells was a decline of $0.8 \mathrm{ft}$, and changes ranged from a decline of $18.7 \mathrm{ft}$ to a rise of $8.9 \mathrm{ft}$. In unconfined areas, water levels declined in 11 of 15 wells, and the median change was a decline of $0.7 \mathrm{ft}$. In confined areas, water levels declined in 14 of 16 wells, and the median change was a decline of $1.2 \mathrm{ft}$.

From 1998 to 1999, the water levels declined by a median of $0.7 \mathrm{ft}$ in unconfined areas; however, the average annual median change from 1983 to 1999 was $+0.2 \mathrm{ft}$. The median decline of $1.2 \mathrm{ft}$ in confined areas was a slightly smaller decline than the average annual median decline of $1.9 \mathrm{ft}$.

From the prestress period (prior to 1965) to 1999 , water levels in the 31 wells declined by a median of $10.6 \mathrm{ft}$. Water levels in the 15 wells in the unconfined part of the aquifer had a median change of $0.0 \mathrm{ft}$ and ranged from a decline of $38 \mathrm{ft}$ to a rise of $14 \mathrm{ft}$. Water levels in the 16 wells in the confined part of the aquifer had a median decline of $45.5 \mathrm{ft}$ and ranged from a decline of $174.8 \mathrm{ft}$ to a rise of $0.6 \mathrm{ft}$.

Discharges were measured annually at four springs in 1998 and 1999. Burro Spring had no changes in discharge, an unnamed spring near Dennehotso had a 30-percent decrease, Moenkopi School Spring had an 11-percent increase, and Pasture Canyon Spring had a
3 -percent decrease. For about the past 10 years, discharges in the four springs have fluctuated; however, increasing or decreasing trends are not apparent.

The annual average discharges for the four streamflow-gaging stations vary considerably during their periods of record; therefore, it is difficult to discern any trends. Continuous records of surfacewater discharge have been collected from July 1976 to 1999 at Moenkopi Wash, July 1976 to 1999 at Laguna Creek, June 1993 to 1999 at Dinnebito Wash, and April 1994 to 1999 at Polacca Wash. Median flows for November, December, January, and February of each water year are used as an index of ground-water discharge to those streams. Increasing or decreasing trends are not apparent in these median winter flows for the periods of record.

In 1999, water samples were collected from 12 wells and analyzed for selected chemical constituents. Dissolved-solids concentrations ranged from 91 to 630 $\mathrm{mg} / \mathrm{L}$, and samples from 10 of the 12 wells had dissolved-solids concentrations less than $275 \mathrm{mg} / \mathrm{L}$. Water-chemistry data are available for nine wells and four springs from about the mid-1980s. For that time period, the data from those sites have remained fairly stable.

Dissolved-solids concentrations in water samples from an unnamed spring near Dennehotso, Pasture Canyon Spring, and Moenkopi School Spring ranged from 110 to $192 \mathrm{mg} / \mathrm{L}$, and dissolved-solids concentration in the water sample from Burro Spring was $346 \mathrm{mg} / \mathrm{L}$. Trends are not apparent in the concentrations of dissolved solids, chloride, and sulfate from the early 1980s to 1999 at Burro Spring, an unnamed spring near Denne- hotso, and Pasture Canyon Spring. From 1987-99, concentrations of those constituents appear to be increasing slightly at Moenkopi School Spring.

\section{SELECTED REFERENCES}

Boner, F.C., Davis, R.G., and Duet, N.R., 1992, Water resources data for Arizona, water year 1991: U.S. Geological Survey Water-Data Report AZ-91-1, 411 p.

Boner, F.C., Garrett, W.B., and Konieczki, A.D., 1989, Water resources data for Arizona, water year 1988: U.S. Geological Survey Water-Data Report AZ-88-1, 391 p.

Boner, F.C., Konieczki, A.D., and Davis, R.G., 1991, Water resources data for Arizona, water year 1990: U.S. Geological Survey Water-Data Report AZ-90-1, 381 p. 
Boner, F.C., Smith, C.F., Garrett, W.B., and Konieczki, A.D., 1990, Water resources data for Arizona, water year 1989: U.S. Geological Survey Water-Data Report AZ89-1, 383 p.

Brown, J.G., and Eychaner, J.H., 1988, Simulation of five ground-water withdrawal projections for the Black Mesa area, Navajo and Hopi Indian Reservations, Arizona: U.S. Geological Survey Water-Resources Investigations Report 88-4000, 51 p.

Cooley, M.E., Harshbarger, J.W., Akers, J.P., and Hardt, W.F., 1969, Regional hydrogeology of the Navajo and Hopi Indian Reservations, Arizona, New Mexico, and Utah: U.S. Geological Survey Professional Paper 521A, $61 \mathrm{p}$.

Davis, G.E., Hardt, W.F., Thompson, L.K., and Cooley, M.E., 1963, Records of ground-water supplies, part 1, of Geohydrologic data in the Navajo and Hopi Indian Reservations, Arizona, New Mexico, and Utah: Arizona State Land Department Water- Resources Report 12-A, $159 \mathrm{p}$.

Dubiel, R.F., 1989, Sedimentology and revised nomenclature for the upper part of the upper Triassic Chinle Formation and the lower Jurassic Wingate Sandstone, northwestern New Mexico and northeastern Arizona, in Anderson, O.J., Lucas, S.G., Love, D.W., and Cather, S.M., eds., Southeastern Colorado Plateau: New Mexico Geological Society Fortieth Annual Field Conference, September 28-October 1, 1989, p. 213223.

Eychaner, J.H., 1983, Geohydrology and effects of water use in the Black Mesa area, Navajo and Hopi Indian Reservations, Arizona: U.S. Geological Survey WaterSupply Paper 2201, 26 p.

Garrett, J.M., and Gellenbeck, D.J., 1991, Basin characteristics and streamflow statistics in Arizona as of 1989: U.S. Geological Survey Water-Resources Investigations Report 91-4041, 612 p.

GeoTrans, Inc., 1987, A two-dimensional finite- difference flow model simulating the effects of withdrawals to the $\mathrm{N}$ aquifer, Black Mesa area, Arizona: Boulder, Colorado, GeoTrans, Inc., report prepared for Peabody Western Coal Company.

Harshbarger, J.W., Lewis, D.D., Skibitzke, H.E., Heckler, W.L., and Kister, L.R., 1966, Arizona water: U.S. Geological Survey Water-Supply Paper 1648, 85 p.

Hart, R.J., and Sottilare, J.P., 1988, Progress report on the ground-water, surface-water, and quality-of-water monitoring program, Black Mesa area, northeastern Arizona-1987-88: U.S. Geological Survey Open-File Report 88-467, 27 p. 1989, Progress report on the ground-water, surfacewater, and quality-of-water monitoring program, Black Mesa area, northeastern Arizona-1988-89: U.S. Geological Survey Open-File Report 89-383, 33 p.
Hill, G.W., 1985, Progress report on Black Mesa monitoring program-1984: U.S. Geological Survey Open-File Report 85-483, 24 p.

Hill, G.W., and Sottilare, J.P., 1987, Progress report on the ground-water, surface-water, and quality-of- water monitoring program, Black Mesa area, northeastern Arizona-1987: U.S. Geological Survey Open-File Report 87-458, 29 p.

Hill, G.W., and Whetten, M.I., 1986, Progress report on Black Mesa monitoring program-1985-86: U.S. Geological Survey Open-File Report 86-414, 23 p.

HSIGeoTrans, Inc., 1993, Investigation of the N- and Daquifer geochemistry and flow characteristics using major ion and isotopic chemistry, petrography, rock stress analyses, and dendrochronology in the Black Mesa area, Arizona: Boulder, Colorado, HSIGeoTrans, Inc., report prepared for Peobody Coal Company.

HSIGeoTrans, Inc., and Waterstone Environmental Hydrology and Engineering, Inc., 1999, A threedimensional flow model of the $\mathrm{D}$ and $\mathrm{N}$ aquifers, Black Mesa Basin, Arizona: Boulder, Colorado, HSIGeoTrans, Inc., and Waterstone Environmental Hydrology and Engineering, Inc., report prepared for Peabody Western Coal Company.

Kister, L.R., and Hatchett, J.L., 1963, Selected chemical analyses of the ground water, pt. 2 of Geohydrologic data in the Navajo and Hopi Indian Reservations, Arizona, New Mexico, and Utah: Arizona State Land Department Water-Resources Report 12-B, 58 p.

Littin, G.R., 1992, Results of ground-water, surface- water, and water-quality monitoring, Black Mesa area, northeastern Arizona-1990-91: U.S. Geological Survey Water-Resources Investigations Report 924045, 32 p. 1993, Results of ground-water, surface-water, and water-quality monitoring, Black Mesa area, northeastern Arizona-1991-92: U.S. Geological Survey Water-Resources Investigations Report 934111, 23 p.

Littin, G.R., and Monroe, S.A., 1995a, Results of groundwater, surface-water, and water-quality monitoring, Black Mesa area, northeastern Arizona-1992-93: U.S. Geological Survey Water- Resources Investigations Report 95-4156, 37 p. 1995b, Results of ground-water, surface-water, and water-chemistry monitoring, Black Mesa area, northeastern Arizona-1994: U.S. Geological Survey Water-Resources Investigations Report 95-4238, 25 p. 1996, Ground-water, surface-water, and waterchemistry data, Black Mesa area, northeastern Arizona-1995: U.S. Geological Survey Open-File Report 96-616, 22 p. 1997, Ground-water, surface-water, and waterchemistry data, Black Mesa area, northeastern 
Arizona-1996: U.S. Geological Survey Open-File Report 97-566, 27 p.

Littin, G.R., Baum, B.M., and Truini, Margot, 1999, Ground-water, surface-water, and water-chemistry data, Black Mesa area, northeastern Arizona-1997: U.S. Geological Survey Open-File Report 98-653, 27 p.

Lopes, T.J., and Hoffmann, J.P., 1997, Geochemical analyses of ground-water ages, recharge rates, and hydraulic conductivity of the $\mathrm{N}$ aquifer, Black Mesa area, Arizona: U.S. Geological Survey Water- Resources Investigations Report 96-4190, 42 p.

Peterson, Fred, 1988, Stratigraphy and nomenclature of middle and upper Jurassic rocks, Western Colorado Plateau, Utah and Arizona, in Revisions to Stratigraphic Nomenclature of Jurassic and Cretaceous Rocks of the Colorado Plateau: U.S. Geological Survey Bulletin 1633-B, p. 13-56.

Smith, C.F., Anning, D.W., Duet, N.R., Fisk, G.G., McCormack, H.F., Pope, G.L., Rigas, P.D., and Wallace, B.L., 1995, Water resources data for Arizona, water year 1994: U.S. Geological Survey Water-Data Report AZ-94-1, 320 p.

Smith, C.F., Boner, F.C., Davis, R.G., Duet, N.R., and Rigas, P.D., 1993, Water resources data for Arizona, water year 1992: U.S. Geological Survey Water-Data Report AZ-92-1, $360 \mathrm{p}$.

Smith, C.F., Rigas, P.D., Ham, L.K., Duet, N.R., and Anning, D.W., 1994, Water resources data for Arizona, water year 1993: U.S. Geological Survey Water-Data Report AZ-93-1, $360 \mathrm{p}$.

Smith, C.F., Duet, N.R., Fisk, G.G., McCormack, H.F., Partin, C.K., Pope, G.L., Rigas, P.D., and Tadayon, Saeid, 1996, Water resources data for Arizona, water year 1995: U.S. Geological Survey Water- Data Report AZ-95-1, $306 \mathrm{p}$.

Smith, C.F., Duet, N.R., Fisk, G.G., McCormack, H.F., Partin, C.K., Pope, G.L., and Rigas, P.D., 1997, Water resources data for Arizona, water year 1996: U.S. Geological Survey Water-Data Report AZ-96-1, 328 p.

Sottilare, J.P., 1992, Results of ground-water, surface- water, and water-quality monitoring, Black Mesa area, northeastern Arizona-1989-90: U.S. Geological Survey Water-Resources Investigations Report 924008, $38 \mathrm{p}$.

Tadayon, Saeid, Duet, N.R., Fisk, G.G., McCormack, H.F., Pope, G.L., and Rigas, P.D., 1998, Water resources data for Arizona, water year 1997: U.S. Geological Survey Water-Data Report AZ-97-1, 416 p.

Truini, Margot, Baum, B.M., Littin, G.R., and SingoitewaHonanie, Gayl, 2000, Ground-water, surface-water, and water-chemistry data, Black Mesa area, northeastern Arizona-1998: U.S. Geological Survey Open-File Report 00-66, 37 p.
U.S. Environmental Protection Agency, 2000, Current drinking water standards, national primary and secondary drinking water regulations: Washington, D.C., U.S. Environmental Protection Agency, accessed June 21, 2000, at url http://www.epa.gov/ safewater/mcl.html.

U.S. Geological Survey, 1963-64a, Surface-water records of Arizona: U.S. Geological Survey report (published annually).

1963-64b, Ground-water records of Arizona: U.S. Geological Survey report (published annually). 1965-74a, Water resources data for Arizona- Part 1, Surface-water records: U.S. Geological Survey Water-Resources Data Report (published annually). 1965-74b, Water resources data for Arizona- Part 2, Ground-water records: U.S. Geological Survey WaterResources Data Report (published annually). 1976-83, Water resources data for Arizona, water years 1975-81: U.S. Geological Survey Water Resources Data Reports AZ-75-1 to AZ-81-1 (published annually).

1978, Progress report on Black Mesa monitoring program-1977: U.S. Geological Survey Open-File Report 78-459, 38 p.

Waterstone Environmental Hydrology and Engineering Inc. (formerly Brogan-Johnson Consultants, Inc.), 1995, Evaluating the reliability of input parameters and their influence on model predictions using MODFLOWPUSGS N-aquifer flow model, Black Mesa, Arizona: Boulder, Colorado, Waterstone Environmental Hydrology and Engineering, unpaged.

White, N.D., and Garrett, W.B., 1984, Water resources data for Arizona, water year 1982: U.S. Geological Survey Water-Data Report AZ-82-1, 440 p. 1986, Water resources data for Arizona, water year 1983: U.S. Geological Survey Water-Data Report AZ83-1, $387 \mathrm{p}$.

1987, Water resources data for Arizona, water year 1984: U.S. Geological Survey Water-Data Report AZ84-1, $381 \mathrm{p}$.

1988, Water resources data for Arizona, water year 1985: U.S. Geological Survey Water-Data Report AZ$85-1,343 \mathrm{p}$.

Wilson, R.P., and Garrett, W.B., 1988, Water resources data for Arizona, water year 1986: U.S. Geological Survey Water-Data Report AZ-86-1, 341 p. 1989, Water-resources data for Arizona, water year 1987: U.S. Geological Survey Water-Data Report AZ87-1, $385 \mathrm{p}$.

Zhu, C., Waddell, R.K., Star, I., and Ostrander, M., 1998, Responses of ground water in the Black Mesa Basin, northeastern Arizona, to paleoclimatic changes during the late Pleistocene and Holocene: Geology, v. 26, no. 2, p. 127-130. 